\title{
Biomimetic Aspects of Oral and Dentofacial Regeneration
}

\author{
Akshaya Upadhyay ${ }^{\dagger}$, Sangeeth Pillai ${ }^{\dagger} \oplus$, Parisa Khayambashi, Hisham Sabri ${ }^{\oplus}$, Kyungjun T. Lee, \\ Maryam Tarar, Stephanie Zhou, Ingrid Harb and Simon D. Tran * \\ McGill Craniofacial Tissue Engineering and Stem Cells Laboratory, Faculty of Dentistry, McGill University, \\ 3640 University Street, Montreal, QC H3A 0C7, Canada; akshaya.upadhyay@mail.mcgill.ca (A.U.); \\ sangeeth.pillai@mail.mcgill.ca (S.P.); parisa.khayambashi@mail.mcgill.ca (P.K.); \\ hisham.sabri@mail.mcgill.ca (H.S.); kungjun.lee@mail.mcgill.ca (K.T.L.); maryam.tarar@mail.mcgill.ca (M.T.); \\ stephanie.zhou@mail.mcgill.ca (S.Z.); ingrid.harb@mail.mcgill.ca (I.H.) \\ * Correspondence: simon.tran@mcgill.ca \\ + These authors contributed equally to this work.
}

Received: 15 September 2020; Accepted: 10 October 2020; Published: 12 October 2020

check for updates

\begin{abstract}
Biomimetic materials for hard and soft tissues have advanced in the fields of tissue engineering and regenerative medicine in dentistry. To examine these recent advances, we searched Medline (OVID) with the key terms "biomimetics", "biomaterials", and "biomimicry" combined with MeSH terms for "dentistry" and limited the date of publication between 2010-2020. Over 500 articles were obtained under clinical trials, randomized clinical trials, metanalysis, and systematic reviews developed in the past 10 years in three major areas of dentistry: restorative, orofacial surgery, and periodontics. Clinical studies and systematic reviews along with hand-searched preclinical studies as potential therapies have been included. They support the proof-of-concept that novel treatments are in the pipeline towards ground-breaking clinical therapies for orofacial bone regeneration, tooth regeneration, repair of the oral mucosa, periodontal tissue engineering, and dental implants. Biomimicry enhances the clinical outcomes and calls for an interdisciplinary approach integrating medicine, bioengineering, biotechnology, and computational sciences to advance the current research to clinics. We conclude that dentistry has come a long way apropos of regenerative medicine; still, there are vast avenues to endeavour, seeking inspiration from other facets in biomedical research.
\end{abstract}

Keywords: biomimetics; dentistry; dentofacial; regeneration

\section{Introduction}

The term "biomimetics" was derived from the Greek words "bios" (meaning life) and "mimesis" (meaning to imitate). It originally meant developing any new material or technology that mimics nature or is obtained from nature. In biology, biomimetics relates to harnessing bioinspired materials or molecules, either synthetic replacements of natural structures or derivations from living organisms that simulate biological mechanisms. The field of tissue engineering and regenerative medicine (TERM) has developed significantly over the past decade with the main focus on the synthesis of novel, highly intricate biomaterials and techniques to regenerate and replace lost structures. However, in light of the human body's complex anatomy and functions, it has always remained a challenge to develop state-of-the-art, accurate, bio-replacements for different tissues and organs. The craniofacial region is residence to living paradoxes, with hardest to the softest tissues, and involves a macromolecular to nanomolecular range of therapies. Each tissue and organ has their own peculiarities that have to be dealt with to achieve the utmost biological resemblance to natural tissues. Biomimetic dentistry has come a long way in engineering and regenerating dental hard and soft tissues unprecedentedly. We hypothesize 
that biomimetic improvements are highly essential in successfully engineering dentofacial structures. This current review provides a glimpse of the volumes of work that has been done over the past decade to improve these aspects. The purpose of this study is to establish a guide to new researchers, clinicians, and dentists at all stages of research to help them develop a perspective of biomimetics and its importance in clinical therapies, specifically in restorative dentistry, oral and maxillofacial surgery, and periodontology.

The literature was searched on Medline (OVID) with key terms like "biomimetics", "biomaterials", and "biomimicry" combined with MeSH terms for "dentistry", and a limit was set to 2010-current, where over 500 articles were obtained under clinical trials, randomized clinical trials, metanalysis, and systematic reviews together. Out of the obtained search, relevant clinical studies have been included with systematic reviews, along with hand-searched preclinical studies as potential therapies wherever deemed necessary. A brief discussion on enamel regeneration and recent outlooks in pulp regeneration has been covered. Pulp tissue is a complex connective tissue with multiple functions including protective, nutritive, and reparative activities. Infection to pulp due to caries or trauma usually results in complete pulp removal. This makes the tooth structure more fragile and prone to fracture. Therefore, it is important to use the most biomimetically advanced material in these situations to preserve or replace the pulp tissue to save the tooth structure. We have discussed the most significant biomimetic analogues for tooth structure and different scaffolds for dentin pulp complex regeneration. Further, we have focused on the current preclinical and clinical studies in orofacial bone regeneration and a brief overview of strategies for repair of the oral mucosa under oral and maxillofacial dentistry. As important as the tooth structure, it is also essential to understand the supporting periodontal structure, which are the hard and soft tissue that surround the tooth that undergoes competitive regeneration processes. An array of different tissue engineering strategies and surgical methods are used today to induce regeneration of the complex highly cellular periodontium, and thus, in the last section of this review, we cover the current facets in periodontal tissue engineering, including cell and cell-free approaches and guided tissue regeneration, with a brief description of implant biomimetics.

\section{Biomimetics in Restorative Dentistry}

\subsection{Enamel Biomimetics}

Enamel is the outermost hard tissue covering the crown of the tooth structure. It is considered the hardest substance in the body due to its high inorganic content (96\%), mostly comprised of interwoven hydroxyapatite crystals arranged in a three-dimensional pattern, giving it superior aesthetic and structural properties [1]. However, continuous and complex changes occurring within the oral microenvironment sometimes lead to enamel demineralisation, thereby initiating caries formation. Dental caries affects more than two-thirds of the world's population and is highly prevalent among people of all ages. The origination of caries is contributed by a multitude of factors including the presence of cariogenic bacteria, dietary carbohydrates, decreased salivary flow, or xerostomia. Usually, there is a balance between the demineralisation and remineralisation processes in the oral cavity, but this equilibrium is lost due to factors consistently favouring tooth demineralisation, leading to primary white spot lesions, caries progression, and eventually cavitation [2]. Proper teeth cleaning to get rid of cariogenic bacteria, adequate salivary flow, and the presence of sufficient amounts of calcium and phosphate ions in saliva can help control the limit of tooth demineralisation to a certain extent. However, since the body's natural defence might not be enough to resist caries, in many cases, minimally invasive dentistry approaches are used in a desperate attempt to remove initial caries and to preserve as much of the natural tooth structure to maintain the functional integrity and aesthetics of the tooth. Nevertheless, enamel regeneration still remains a challenging task, and it becomes even more complex on clinical implementation. Therefore, it is essential to look at alternate methods for enamel repair and engineer biomaterials that mimics the natural enamel both biologically and structurally. Pandya et al. (2019) described four different pathways for enamel tissue engineering 
and regeneration (Figure 1) by (a) physiochemical synthesis, (b) protein-matrix-guided enamel crystal development, (c) enamel surface remineralisation, and (d) cell-based regeneration [3]. We will discuss these approaches with their most recent advances in enamel mimetics.

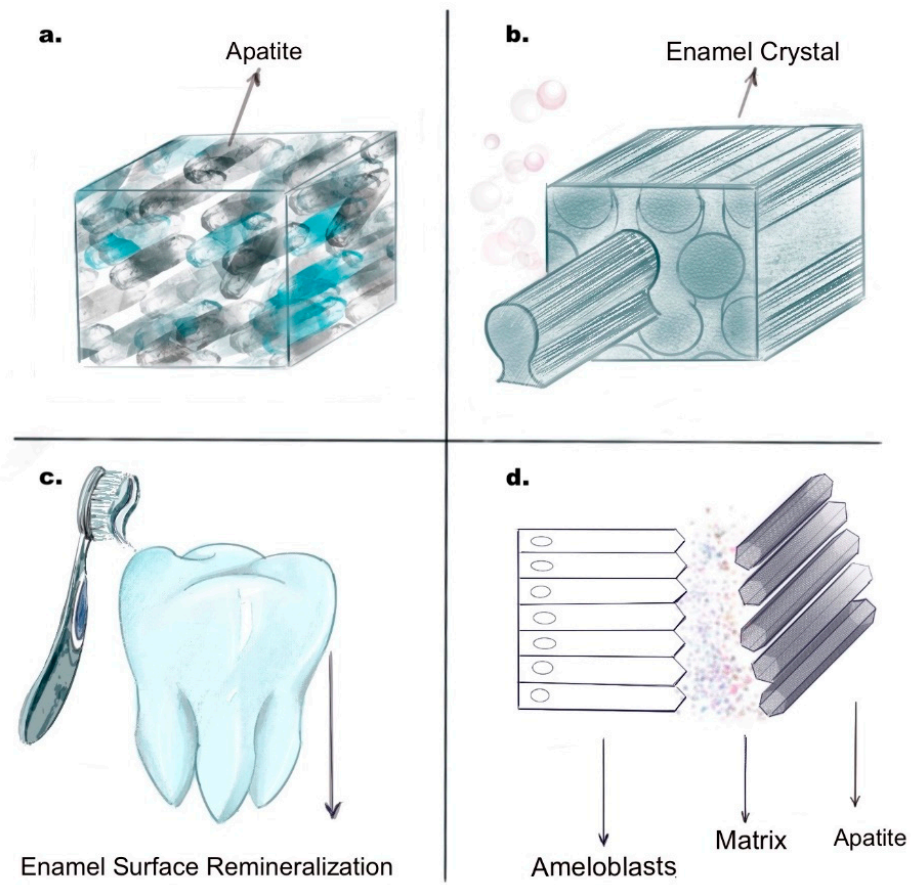

Figure 1. Mechanisms of enamel tissue engineering and regeneration: (a) physiochemical synthesis of apatite crystals, (b) protein-matrix-guided enamel crystal development, (c) enamel surface mineralisation using fluoride toothpastes, and (d) ameloblast (cell-based) tissue engineering of synthetic enamel apatite. Image adapted from [3] Pandya, M.; Diekwisch, T.G.H. Enamel biomimetics-fiction or future of dentistry. Int. J. Oral Sci. 2019, 11, 8. Copyright 2019 Springer Nature.

\subsubsection{Physiochemical Synthesis}

Biomimetic substitutes developed to replace the natural tooth enamel are synthesized using extreme conditions to simulate the natural enamel structure, which includes use of high temperature and pressure [4]. Chen et al. (2005) first described the possible development of synthetic hydroxyapatite nanocrystals, which mimicked the enamel prism-like structures [4]. Their study showed how a combination of aqueous hydroxyapatite and docusate sodium salt, when adjusted to a pH of 5.5, led to precipitation of long apatite crystals around $200-400 \mathrm{~nm}$ in size. Further, to limit these rods' size, the hydroxyapatite aqueous solution was replaced with a fluorapatite solution and processed under extreme hydrothermal pressures, leading to enamel rods with a size around 5-10 micron matching the natural enamel size (Figure 1a). Fan et al. (2009) developed controlled remineralisation of enamel hydroxyapatite crystals using amelogenin and fluoride with a newly developed methodology to sequentially form fluoridated needle-like enamel crystals. The biomimetic solution was prepared using commercially obtained calcium and phosphates at $2.5 \mathrm{mM}$ and $1.5 \mathrm{mM}$, respectively, at $37^{\circ} \mathrm{C}$ with $50 \mathrm{mM}$ trihydroxymethylaminomethane-hydrochloric acid and $180 \mathrm{mM} \mathrm{NaCl}$ buffer at $7.6 \mathrm{pH}$. Fluoride concentration from $\mathrm{NaF}$ was kept at $1 \mathrm{mg} / \mathrm{L}$ to form the desired solution, and previously obtained tooth slices were treated with $3 \% \mathrm{HNO}_{3}$ solution for 50 seconds followed by immersion in the biomimetic solution. Scanning electron microscopy (SEM) results showed the formation of flake-like fused crystals on the enamel's surface, which was porous in structure. CaP (calcium phosphate) nanorods formed were around $25 \mathrm{~nm}$ in diameter and $100 \mathrm{~nm}$ in length [5]. A few years later, an approach established by Ren et al. (2012) used a sodium bicarbonate buffer solution and a mixture containing calcium nitrate tetrahydrate, sodium bicarbonate, disodium hydrogen phosphate, 
and octa calcium phosphate, all maintained at a $\mathrm{pH}$ of 6.6 , resulting in the formation of human enamel-like crystals with a size ranging between 100-500 nm [5]. An essential modification applied to their crystallisation approach was the use of high temperatures $\left(150-200{ }^{\circ} \mathrm{C}\right)$ constantly for $72 \mathrm{~h}$. However, the $\mathrm{pH}$ and pressure range were maintained at standard conditions. More recently, Wang et al. (2017) described a three-step process to form enamel to mimic the natural enamel formation sequalae. First, they conjugated the carboxymethyl chitosan (CMC) with a bisphosphonate alendronate, which stabilised the amorphous calcium phosphate (ACP) to form a CMC/ACP nanoparticle complex. The second step used a sodium hypochlorite solution to break the CMC/ACP nanoparticles formed in the first step. Once the nanoparticles were degraded, glycine was added to orient the ACP/CMC to form a well-organized and spatially arranged enamel rods. This technique is notable as it simulates the biologic amelogenesis process and supports the initial layering of amelogenin matrix protein, leading to cell-matrix and matrix-crystal interactions and subsequently to the elongation of apatite crystals [6].

\subsubsection{Protein-Matrix-Guided Synthesis}

Enamel engineering using protein matrix formation aims to biologically mimic the natural process of tooth enamel development. It involves the synthesis of amelogenin-rich proteins followed by their conjunction with calcium and phosphate ions. This technique usually involves enzymatic processing with enamel proteases like matrix metalloproteases 20 (MMP 20) and kallikrein 4, which provide a three-dimensional axis for crystal growth [3] (Figure 1b). The three major proteases that pave ways for enamel matrix development are amelogenin, ameloblastin, and enamelin [7]. During amelogenesis, each matrix protein plays a vital role in enamel matrix layering and the consequent crystal growth. Some earlier studies showed the use of octacalcium phosphate solutions along with amelogenin $(10 \% w / v)$ to initiate crystal formation [8]. Similar studies using other combinations of enamel matrix proteins with octacalcium resulted in a more organized, better apatite crystal structure formation [9]. However, these combinations did not completely mimic the natural enamel structure in terms of their arrangement, hardness, or strength. More recently, studies focussed on understanding how the amelogenin amino acid chains are formed and the mechanism of their interaction with developing enamel crystals [10]. For example, Li et al. (2014) described the interaction between a leucine-rich 59 peptide amelogenin synthesized using an alternate splicing technique, which showed a tendency to form spheroidal nanoparticles arranged in a linear pattern [11]. With the development and understanding of better biomimetic materials like chitosan, a chitosan gel-based combination of amelogenin fragments with MMP 20 added to calcium phosphate crystal solution was studied and tested. This led to the breakdown of amelogenin fragments after primary crystal formation with improved biomechanical properties for the subsequently formed apatite crystals [12]. However, even today, most of these methods only manage to focus on matrix formation and crystal formation as separate entities, and a more sophisticated, novel technique needs to be developed to mimic the in vivo aspects of enamel formation.

\subsubsection{Enamel Surface Mineralisation}

As described earlier, enamel mineralisation is a complex and multifactorial process. However, excessive demineralisation leads to white spot lesions, which marks the initiation of caries. Several approaches have been tried over the years to induce surface remineralisation. The impacts of fluoridation on tooth structure has been investigated for over a century now, and the results clearly indicate their current applications in dentistry (Figure 1c). Fluoride ions usually move the bioavailable calcium and phosphates from saliva and lead to fluorapatite formation, which has superior resistance to enamel demineralisation and thereby limits caries progression [13]. Based on this principle, several innovative oral care products have been developed. Most of them include the use of fluoridated toothpastes and other fluoride-containing products like varnishes and mouthwashes. Casein phosphopeptide (CPP)-amorphous calcium phosphate (ACP) combinations are used for improving enamel surface remineralisation owing to their ability to stabilise calcium, phosphate, and fluoride ions, which are 
already available in saliva, leading to faster and better surface remineralisation of the enamel layer [14]. Ma et al. (2019) conducted a systematic review with metanalyses describing the efficiency of CCP-ACP in enamel remineralisation. They summarised 12 studies based on the inclusion and exclusion criteria, which were evaluated either by surface roughness or their microhardness values. The evaluation showed significant heterogenicity in the surface hardness values, due to which a random model of analysis was performed which included 5 of the 8 studies selected and which showed values $(\mathrm{SMD}=1.19,95 \% \mathrm{CI}:[0.72,1.66], p<0.00001)$ indicating that the use of CPP-ACP resulted in superior remineralisation. The atomic force microscopy (AFM) analysis of three of their studies also showed that $\mathrm{CPP}-\mathrm{ACP}$ 's use resulted in reduced roughness of the enamel surface and showed their ability to repair and form a smooth surface $[14,15]$. In another study by Fernando et al. which described the use of SnF2 along with ACP-CCP to induce tooth repair, their in-vitro studies showed the ability of SnF2 to interact with CPP-ACP complexes to form a nanofilament coating on the tooth surface, with superior remineralisation activity in comparison to either of these materials individually. The mechanism involves Sn2 to form cross-links with CPP-ACP to stabilise the bioavailable minerals and to thereby enhance binding of the ion binding to the tooth minerals. The results showed that this novel combination can help to significantly improve resistance to caries and dentinal hypersensitivity [15]. A study by Bossu et al. (2019) compared a biomimetic nanoparticle-infused hydroxyapatite toothpaste with two other toothpastes with different fluoride concentrations. Their focus was directed towards how nanoparticle-based HA integrated to enamel surface and formed a coating that is similar to natural enamel apatite structures. This technique avoids any physiochemical reaction between fluoride ions and enamel crystals and, at the same time, is more resistant to brushing abrasions and grindings due to superior chemical bond between the old enamel and new layer of apatite crystals formed [16]. These modifications provide better resistance to caries while prevent the risk of fluorosis due to the overuse of fluoride-based substituents. Use of bioactive glass for enamel white spot lesions have been studied extensively in the last few years [17]. These glass particles when in contact with physiological fluids has the ability to from new apatite crystals, thus essentially remineralising the enamel surface. Besides, these glasses when incorporated with fluoride formed the more resistant fluorapatite layering over enamel surface. This has allowed their use in toothpastes, varnishes, and dental cements to treat carious lesions. In a recent systematic review by Taha et al., they compared the efficiency of different toothpastes containing fluorides, ACP-CPP combinations and bioactive glass and evaluated the different studies showing efficiency of each material in improving white spot lesions [18]. Many studies showed the superior properties of bioactive glasses in forming a mineral layer on an enamel surface rich in calcium, phosphate, and silica [17]. Some studies showed the improved mechanical properties in newly formed enamel using bioactive glass-based toothpastes $[19,20]$. Based on these studies, bioactive glasses were ranked above both fluoride and casein peptidases in remineralising enamel white spot lesions and are an effective alternate option.

\subsubsection{Cell and Tissue Culture Systems for Enamel Organ Engineering}

Enamel tissue engineering approaches ideally include complex interactions between enamel forming cells (chiefly ameloblasts) with biomimetic scaffolds and enamel proteins to form suitable in vitro conditions to engineer new enamel crystals (Figure 1d). Although cell- and tissue-based engineering approaches have been used for developing several organs and structures in the human body, enamel bioengineering still remains a daunting challenge due to the highly sensitive nature of the ameloblast cells and the inability to retrieve enamel organ stem cells with superior pluripotency as they are lost immediately after tooth eruption [21]. The lack of a suitable and more stable ameloblast cell line is another drawback in enamel tissue engineering. Currently available ameloblast cell lines usually rely on the feeder layer system to provide sufficient nutritional support or interaction between mesenchymal cells (feeder layer) to induce primary ameloblast cell growth. The currently available ameloblast cell line includes the mouse ameloblast-lineage cell line (ALC), the rat dental epithelial cell line (HAT-7), mouse LS8 cell line, porcine PABSo-E cell line [22], and the rat SF2-24 cell line [23]. The ALC is the oldest of all 
the cell lines and expresses amelogenin and tuftlins that are important markers, indicating their close relation to ameloblast-like cells. Even the other cell lines mentioned show ameloblastic characteristics, but each of them moreover focuses on one or other specific markers or areas of enamel formation and, therefore, still remains an insufficient tool to accurately simulate in vivo enamel development [3]. However, well-characterized, more specifically, human stem cell-derived cell lines in combination with supporting scaffolds and matrix proteins may help bridge the current knowledge gap and limitations in synthetic engineering enamel. On successfully developing such biomimetic enamel regenerative systems, the future of dental restorative therapies can be immensely benefited.

\subsection{Biomimetic Aspects of Dentin and Dentin-Pulp-Complex Regeneration}

Dentin forms the bulk of the tooth structure and is a highly complex tissue: $70 \%$ of the dentin structure is attributed to its mineral composition, and the remaining $30 \%$ is attributed to its organic content and water. In the tooth structure, there are of two types: (1) peripheral or mantle dentin and (2) circumpulpal dentin. The mantle dentin forms the hard outer layer of dentin, whereas the circumpulpal dentin, as its name suggests, makes up the larger part of the dentin and surrounds the entire pulp tissue [24]. The lower mineral content of the dentin biostructure makes them prone to quicker demineralisation than enamel. Its complex structure makes its remineralisation slower, and consequently, the spread of caries into dentin is enhanced, causing infection of the pulp tissue and, eventually, periapical diseases. In this context, it is essential to develop smart and effective biomaterials to replace lost tissue mineral and organic content to form dentinal tubules and to induce remineralisation. Several materials and bioactive analogues can induce this process; however, in this review, we discuss the key strategies for dentin remineralisation.

Use of resin-based adhesives and bioactive glass for dentin remineralisation is an established approach for caries affected or partially demineralised dentin, which involves the deposition of newly formed dentin on the previously carious dentin surfaces [25]. Bioactive glass (BAG) causes effective remineralisation of dentin and improves the mechanical properties of the dentin structure through intrafibrillar mineralisation. This allows to maintain the functionality of the tissue in addition to superior physical properties. However, in this type of dentin formation, lack of seed crystals or the old dentin crystals will affect the formation of new dentin. For these reasons, ion-based dentin regeneration may not be sufficient to remineralise dentin that has already been entirely demineralised by caries [26]. However, ion leaching or an ion releasing approach for dentin caries removal or remineralisation has been widely used (Table 1). It includes using several bioactive and biomimetic analogues which not only replace the lost mineral structure but also, at the same time, protect the collagen fibrils from degradation. The most commonly used biomimetic materials include bioactive glass (BAG), calcium silicates, calcium orthophosphates, and zinc oxide (ZnO) particles. Other non-ion-based biomaterials, which are developed more recently and overcomes the drawbacks of ion-based biomaterials, are described in Table 2.

Table 1. Ion-release-based biomaterials for dentin remineralisation.

\begin{tabular}{ccc}
\hline Material & Modifications and Use & Ref. \\
\hline Bioactive glass (BAG) & $\begin{array}{c}\text { Modified with zinc, copper, fluoride, and PAA (polyacrylic acid), used as adhesive agents } \\
\text { in dentin resin bonding interfaces, and used in dentin hypersensitivity treatment. }\end{array}$ \\
\hline [27-29] & $\begin{array}{c}\text { Di/tricalcium silicates and Mineral trioxide aggregate (MTA); bioactivity by alkalisation of } \\
\text { hydroxyl groups from the CaOH phase, leading to an increase in pH, decreased activity of } \\
\text { MMP, activated mineral precipitation, and antimicrobial activity. }\end{array} \quad \begin{array}{c}\text { [30] } \\
\text { Calcium orthophosphates silicates }\end{array}$ & $\begin{array}{c}\text { Modifications based on different concentrations of Ca-P, dicalcium phosphate anhydrous } \\
\text { (DCPA), dicalcium phosphate dihydrate (DCPD), and tetra calcium phosphate (TTCP) as } \\
\text { resin adhesives for dentin remineralisation and improved dentin resin interfaces. }\end{array}$ \\
\hline ZnO particles & $\begin{array}{c}\text { Zinc oxide and Zn-loaded polymeric nanomaterials additives in resin, protective action in } \\
\text { collagen degradation, and initiation of precipitation of poorly crystallised apatite crystals. }\end{array}$ \\
\hline [32,33]
\end{tabular}


Table 2. Biomimetic analogues for dentin remineralisation.

\begin{tabular}{ccc}
\hline Biomimetic Analogues & Modifications and Use & Ref. \\
\hline Polyacrylic acid9 (PAA9) & $\begin{array}{c}\text { Calcium-binding molecule analogous to dentin matrix protein 1(DMP 1) stabilises } \\
\text { and controls dimensions of calcium carbonate and calcium phosphate phases. }\end{array}$ & [34,35] \\
\hline Polyvinyl phosphonic acid (PVA) & $\begin{array}{c}\text { Functions analogous to collagen-binding matrix phosphoproteins like DMP1 and } \\
\text { dentin phosphoproteins. }\end{array}$ \\
\hline [35,36] & $\begin{array}{c}\text { It is a phosphophoryn analogue, binds to collagen fibrils, creates negatively charged } \\
\text { sites to receive nanoprecursors, and initiates nucleation of apatite crystals. }\end{array}$ \\
\hline [34,37] & $\begin{array}{c}\text { Is an analogue for calcium utilisation, released from hardened calcium silicate } \\
\text { cements or calcium phosphate mineralising solutions, and assists in controlling the } \\
\text { size of ACP nano precursors and their movement into the collagen fibrils. }\end{array}$ \\
\hline [38,39]
\end{tabular}

\subsection{Dentin-Pulp Complex Regeneration}

When carious lesions are left untreated, they extend beyond hard tissues and cause inflammation and, in turn, infection of the pulp and surrounding periapical tissues. In these situations, the treatment plan depends on pulp vitality. In vital pulp therapy, the principle is to induce dentinal bridge formation to protect the pulp tissue. In cases with a nonvital pulp tissue, till today, root canal treatment is the standard of care procedure which removes all necrosed or decayed pulp tissue to clean the tooth canals and to fill them with an inert obturating material which creates a three-dimensional seal both coronally and apically, thus preventing any microleakage and tooth structure preservation. However, easier said than done, endodontic treatments are associated with several posttreatment complications, including periapical pathologies, pain, and secondary infections due to incomplete debris removal or improper techniques used for pulp therapy [40,41]. A study by Prati et al. (2018) showed that, in a 20-year follow up study on post-root-canal-treated patients, $15 \%$ of subjects developed some form of periapical lesion and almost $21 \%$ of these cases ended in extraction of the tooth based on cumulative teeth survival statistics [42]. Therefore, it is evident from the previous studies that there are several drawbacks to the currently used pulp capping and root canal sealing materials, which dictates the need for more refined biomimetic materials with controlled signalling and a more directed differentiation of the pulp cells to limit inflammatory responses and to thus allow better healing. Several approaches are currently being used to fulfil the biologic and structural needs required to eventually preserve the pulp tissue and tooth structure. These include both cell-free (Table 3) and cell-based therapies (Table 4) for dentin pulp complex regeneration. Other methods employ a combination of cells and growth factors which are either directly transplanted to the pulp space (Figure 2) or are laden in combination with biomimetic scaffolds (Table 5) to induce pulp regeneration.

Table 3. Cell-free therapies for dentin and pulp regeneration.

\begin{tabular}{cl}
\hline Biomaterial & \multicolumn{1}{c}{ Indication/Mechanism/Results } \\
\hline & $\begin{array}{l}\text { It is a gold standard, with high pH inducing necrosis and mineralisation, good } \\
\text { antibacterial properties, and formation of heterogeneous dentin bridge with tunnel defects; } \\
\text { it increases recruitment, migration, proliferation, and mineralisation of DPSCs and } \\
\text { periodontal ligament stem cells (PDLSCs) through the expression of STRO-1 and CD146 } \\
\text { markers; and calcium increases the synthesis of biomolecules such as fibronectin and bone } \\
\text { morphogenetic proteins (BMPs) and causes precipitation mineralisation. }\end{array}$ \\
\hline $\begin{array}{l}\text { Mineral trioxide aggregate } \\
\text { (MTA)/Calcium }\end{array}$ & $\begin{array}{l}\text { It has an antibacterial effect by releasing calcium hydroxide, a superior sealing ability, low } \\
\text { solubility, higher strength, and more stability than CaOH; it works well in a moist } \\
\text { environment; it forms thicker dentin bridges; it has less inflammatory response, } \\
\text { hyperaemia and lower pulp tissue necrosis; modifications include calcium chloride } \\
\text { additions, leads to lower setting time, and more biocompatibility; light cured, } \\
\text { resin-modified calcium-silicate-based MTA provides immediate polymerization, material } \\
\text { preservation, and superior physical properties; and it induces generation of proangiogenic } \\
\text { factors like IL-8 and IL-beta (interleukins). }\end{array}$ \\
\hline
\end{tabular}


Table 3. Cont

\begin{tabular}{|c|c|c|}
\hline Biomaterial & Indication/Mechanism/Results & Ref. \\
\hline Bioactive glasses & $\begin{array}{l}\text { It is a mixture of silica, sodium, and phosphorous oxides with the ability to bond to bone } \\
\text { by controlled release of ions forming apatite crystals repairing hard tissues; it mimics the } \\
\text { natural apatite structure; studies show dentin bridge formation on pulp capping, no } \\
\text { necrosis of pulp tissue, and mild inflammatory response; it can form different qualities of } \\
\text { reparative dentin with varying porosities and mechanical properties; and it is noncytotoxic } \\
\text { and improves cell metabolic activities on in vitro testing. }\end{array}$ & {$[53,54]$} \\
\hline CEM (Calcium enriched mixture) & $\begin{array}{l}\text { It has dentinogenic, cementogenic, and osteogenic properties; they increase the expression } \\
\text { of fibroblast growth factor } 4 \text { (FGF-4) and bone morphogenetic protein } 2 \text { (BMP-2), which } \\
\text { favours remineralisation and regeneration. }\end{array}$ & [57] \\
\hline $\begin{array}{l}\text { Glass ionomers and } \\
\text { adhesive resins }\end{array}$ & $\begin{array}{l}\text { It has a proliferative effect on pulp tissue comparable to } \mathrm{CaOH} \text { when used as a lining } \\
\text { material for dentin pulp regeneration, no noticeable antibacterial effect, more } \\
\text { inflammatory response seen on pulp, upregulation of fibroblasts and endothelial cells, and } \\
\text { an inhibitory effect on Hohl cells; in mechanically injured pulp tissue HEMA } \\
\text { (hydroxyethyl methacrylate), it induces secretion of proangiogenic factors like vascular } \\
\text { endothelial growth factors (VEGF) and decreases expression of FGF-2; and concerns } \\
\text { remain regarding the efficiency and quality of tertiary dentin formation after pulp injury. }\end{array}$ & [58-60] \\
\hline Enamel matrix derivatives (EMD) & $\begin{array}{l}\text { It is shown to be more effective than } \mathrm{CaOH} \text { and MTA in differentiation and proliferation of } \\
\text { human tooth germ stem cells; it is highly biocompatible and has known chemotactic effect } \\
\text { and angiogenic effects; studies indicate their use for periodontal regeneration; and it is } \\
\text { inversely shown to cause more inflammation on pulp tissue with little or less hard tissue } \\
\text { formation when compared with } \mathrm{CaOH} \text { application. }\end{array}$ & [61-63] \\
\hline
\end{tabular}

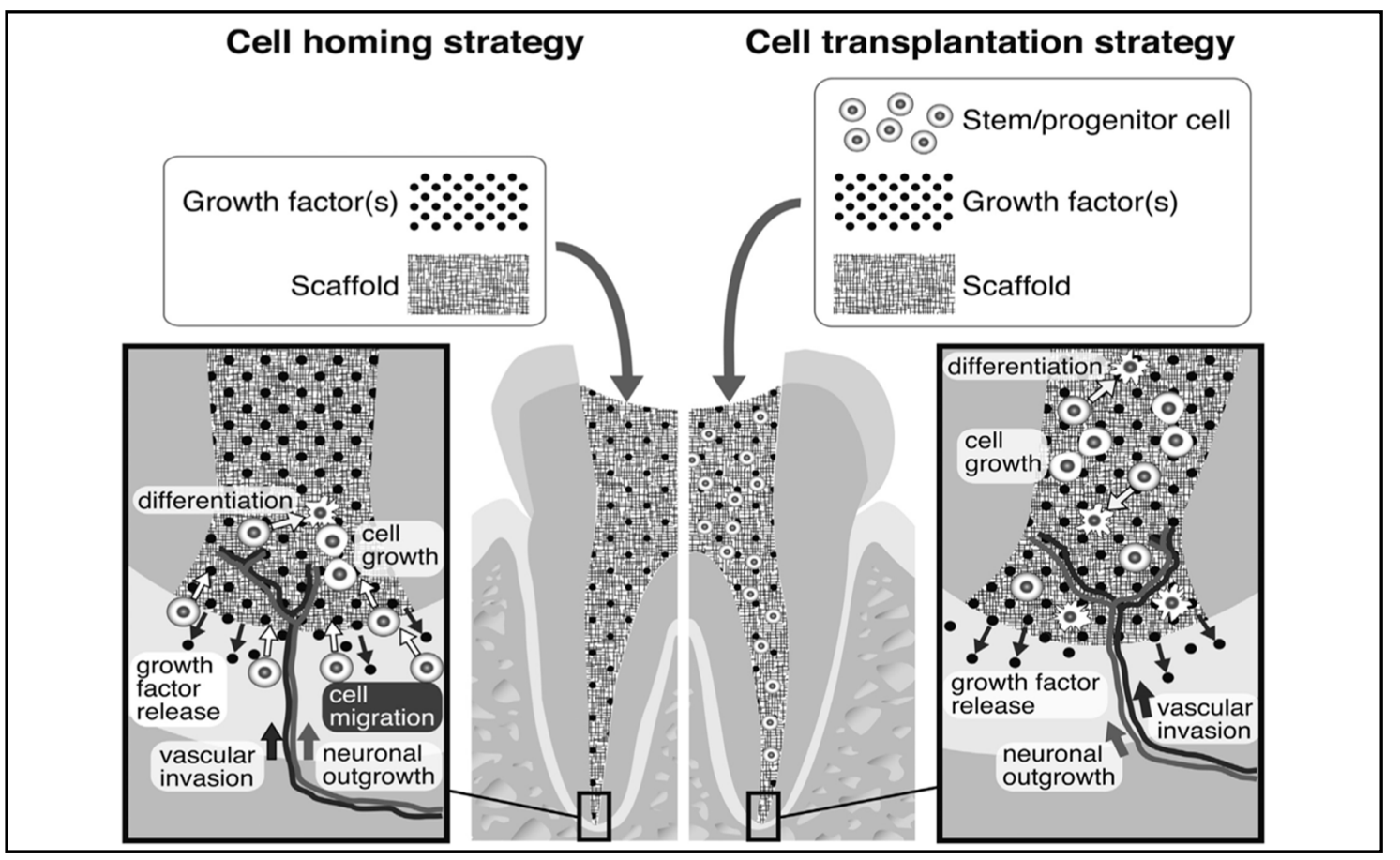

Figure 2. Strategies for dentin pulp complex regeneration: the cell homing strategy involves injection of growth factors and scaffolds into the pulp tissue, which leads to proliferation and migration of progenitor cells from the apical pulp tissue. In cell transplantation, the stem cells are injected to the pulp space along with growth factors and scaffolds to induce pulp regeneration. In both scenarios, cell growth or proliferation due to growth factors or peripheral induction is followed by scaffold colonization, which in cases with resorbable scaffolds leads to formation of new tissue over time. Image reprinted with permission from Morotomi et al. [64]. 
Table 4. Cell-based therapies for dentin pulp complex regeneration (cell transplantation strategies).

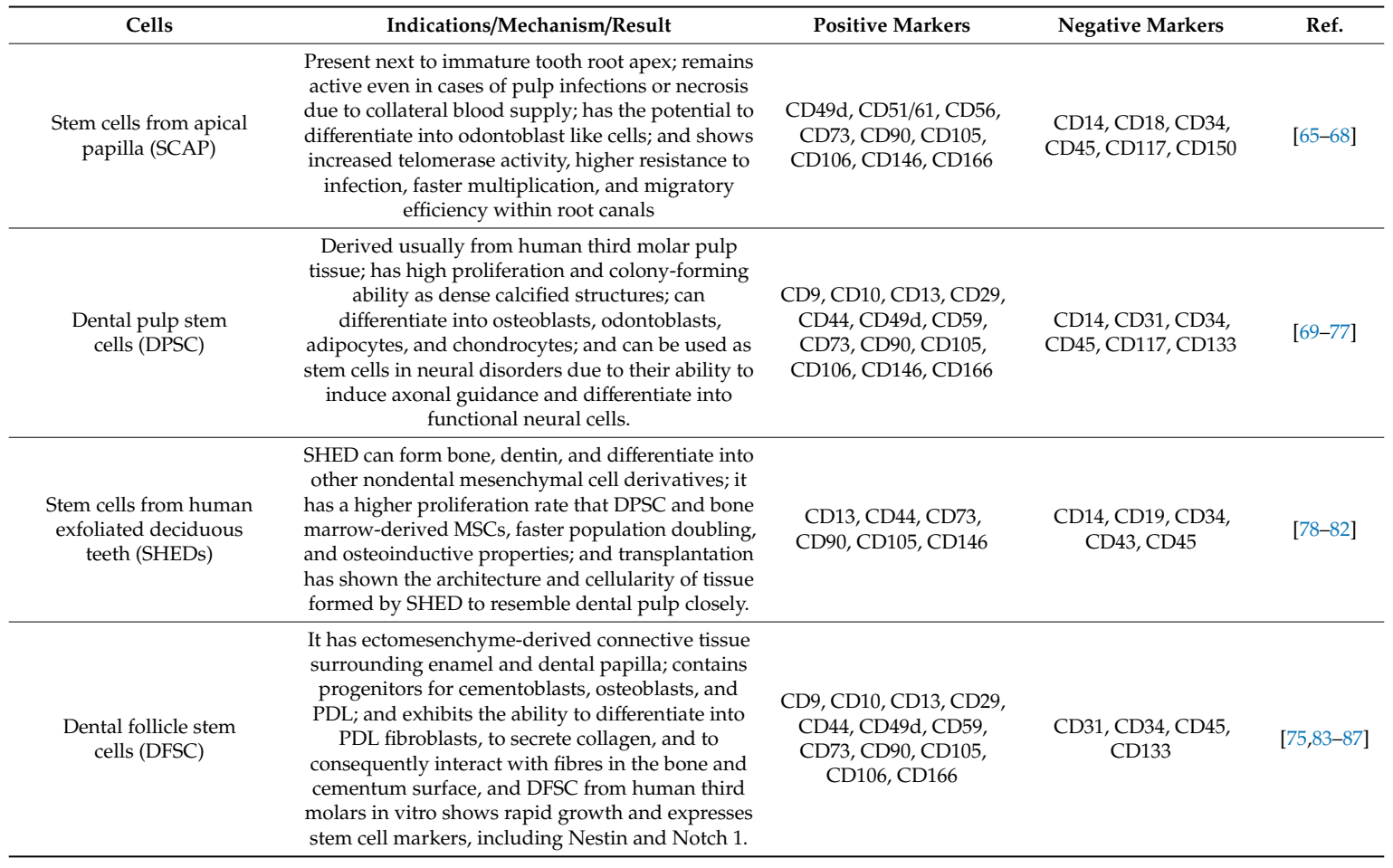

Table 5. Scaffold-based regeneration of the dentin-pulp complex (cell homing strategies).

\begin{tabular}{|c|c|c|}
\hline Scaffold & Indications/Mechanism/Results & Ref. \\
\hline Intracanal blood clot & $\begin{array}{l}\text { It induces apical bleeding, leading to delivery of SCAP to root canal space; it is an autologous } \\
\text { scaffold with growth factors, is clinically efficient, and is economical; and it can be an unstable and } \\
\text { unreliable movement of stem cells within the canal space after revascularization. }\end{array}$ & [88-91] \\
\hline Platelet-rich plasma (PRP) & $\begin{array}{l}\text { Autologous injectable scaffold: it can be delivered via collagen sponges; platelet elevation results in } \\
\text { increased production and secretion of growth factors PDGF, TGF-b, Insulin-like growth factor (IGF), } \\
\text { epidermal growth factor (EGF), and epithelial cell growth factor (ECGF), leading to improved } \\
\text { angiogenesis and cell proliferation }\end{array}$ & {$[88,92]$} \\
\hline Alginate & $\begin{array}{l}\text { Natural polysaccharides from cell walls and seaweeds: stem cells can be incorporated during } \\
\text { scaffold processing; it supports 3-D printing in combination with proteins like DMPs; it includes } \\
\text { easy diffusion of nutrients and waste debris due to porous structure; it is highly biocompatible, has } \\
\text { low immune reactions, is economic, and is easy to fabricate; and has low mechanical strength of the } \\
\text { scaffold when used alone. }\end{array}$ & {$[93,94]$} \\
\hline $\begin{array}{l}\text { Hyaluronic acid (HA) } \\
\text { and derivatives }\end{array}$ & $\begin{array}{l}\text { Glycosaminoglycans which mimic ECM components: it interacts with stem cell receptors and } \\
\text { drives them towards the area of regeneration; it is shown to have a role in dentin matrix and pulp } \\
\text { tissue development; it exhibits good biocompatibility, biodegradability, and bioactivity; HA } \\
\text { derivatives induce proangiogenic factors release; it improves stem cell mineralisation and } \\
\text { odontogenic differentiation; it has low mechanical strength and needs combination with growth } \\
\text { factors to improve regenerative potential; and it may cause hypersensitivity reactions. }\end{array}$ & {$[90,94-97]$} \\
\hline Chitosan derivatives & $\begin{array}{l}\text { Linear amino polysaccharide mimics ECM structure and composition: it is easy to fabricate, is } \\
\text { highly porous, and allows easy migration of cells and growth factors; when fabricated as } \\
\text { nanoparticles, it improved properties due to increased surface area, has better mechanical strength, } \\
\text { and is resistant to enzymatic degradation; it allows the controlled release of growth factors and } \\
\text { improves stem cell or SCAP adhesion, viability, and differentiation; and it is highly biocompatible, } \\
\text { has controlled biodegradation, and has low cytotoxicity with antibacterial properties. }\end{array}$ & [98-100] \\
\hline Gelatin & $\begin{array}{l}\text { Consists of proteins from hydrolysis of hard and soft tissue-derived collagen; they are } \\
\text { biocompatible and biodegradable, elicits no immune responses, and is cost-efficient; they can be } \\
\text { modified with RBDs (receptor binding motifs), which promotes cell attachment and allows chemical } \\
\text { modifications to improve the scaffold's physiochemical properties; it is used as a drug delivery } \\
\text { medium or in 2D and 3D cultures; and the use of FGF-2 with gelatin shows the formation of } \\
\text { osteo-dentin-like calcified tissue for dentin pulp complex regeneration. }\end{array}$ & {$[101,102]$} \\
\hline Cellulose & $\begin{array}{l}\text { Naturally occurring scaffold obtained from green plants and algae: they are not biodegradable due } \\
\text { to the absence of cellulase enzymes in humans; they possess high tensile strength, high crystallinity, } \\
\text { fine fibrous structure, and good formability and is biocompatible; they have higher chances of } \\
\text { immune response; and they are used mostly in target-specific drug delivery or growth factor release } \\
\text { in dental tissue engineering. }\end{array}$ & {$[103,104]$} \\
\hline
\end{tabular}


Table 5. Cont.

\begin{tabular}{cl}
\hline Scaffold & \multicolumn{1}{c}{ Indications/Mechanism/Results } \\
\hline Collagen & $\begin{array}{l}\text { It is a natural biomaterial, is easily adapted to root canal morphology, and mimics ECM; the most } \\
\text { used is type I, suitable for DPSCs proliferation and mineralisation; it is biocompatible, provides } \\
\text { bioactivity by facilitating adhesion and attachment of stem cells, and induces signalling pathways } \\
\text { that promote differentiation; the highly porous structure allows easy cell seeding for site-specific } \\
\text { delivery; and commercially available SynnOss (bovine type 1 collagen) in conjunction with } \\
\text { revascularization forms mineralised cementum-like tissues. }\end{array}$ \\
\hline $\begin{array}{c}\text { Self-assembling peptide } \\
\text { hydrogels -Puramatrix }\end{array}$ & $\begin{array}{l}\text { Synthetic, biocompatible, biodegradable, nontoxic, 3D matrix gel available as a liquid phase, which } \\
\text { solidifies when in contact with a physiologic salt environment: in vitro studies show pure matrix } \\
\text { support DPSC cell proliferation and viability when evaluated over three weeks within tooth slices; } \\
\text { puramatrix showed better in vitro results in terms of cell viability and odontogenic differentiation }\end{array}$ \\
& $\begin{array}{l}\text { [110-113] } \\
\text { when used with a co-culture of DPSC/HUVEC (human umbilical vein endothelial cells). }\end{array}$ \\
\hline $\begin{array}{l}\text { Poly L- Lactic acid (PLLA) } \\
\text { nanofibrous microspheres }\end{array}$ & $\begin{array}{l}\text { Injectable scaffold with integrated BMP-2, when combined with polylactic acid (PLA) and } \\
\text { polyglycolic acid (PGA), significantly improving the properties and half-life of the PLLA and } \\
\text { incorporate drugs/growth factors and is conductive for cells, including DPSC and SHED; it has } \\
\text { favourable viscosity and porosity; it does not elicit any adverse immune response; it is cheap and } \\
\text { reproducible; the regenerated dentin structure may be disorganized and may not replicate the } \\
\text { natural tooth architecture; and degradation metabolites might cause unfavourable conditions for } \\
\text { surrounding cells but can be excreted to urine without complications. }\end{array}$ \\
\hline $\begin{array}{c}\text { Poly (lactide-co } \\
\text { (PLGA-PE) NP }\end{array}$ & $\begin{array}{l}\text { It has better conductivity for dental pulp fibroblasts proliferation; it is clinically biodegradable, has } \\
\text { fast setting, has low toxicity, has good biocompatibility, and has low immunogenicity; but, it lacks } \\
\text { intrinsic signalling abilities and is more expensive than other synthetic scaffolds. }\end{array}$ \\
\hline [106,117]
\end{tabular}

Several materials have been developed and tested to evaluate their potential in dentin and pulp regeneration. So far, a large part of this research focused on comparing these biomaterials in both in vitro and in vivo studies to develop novel smart biomaterials (Figure 3) $[118,119]$. These materials are fabricated in a way that allows easy internal and external modifications based on the inflicted stimuli and thus fulfils all the biomimetic requirements necessary to initiate tooth hard and soft tissue regeneration. However, it has been observed that two biomaterials, Mineral trioxide aggregate (MTA) and $\mathrm{CaOH}$, as well as their modifications were extensively studied in this context by independent researchers. Tabarsi et al. (2012) [120] studied the effect of MTA and Calcium enriched mixture (CEM) on rabbit dorsal skin. They used a fresh mixture of both the materials, which was randomly applied on the skin surface; washed off after $4 \mathrm{~h}$; and evaluated the surface for erythema after 1 , 24,48 , and $72 \mathrm{~h}$. The results showed more erythema on the MTA surface as compared to CEM. On histological examination, MTA showed a higher inflammatory response as compared to CEM. Their study concluded that CEM is a more biocompatible material for endodontic procedures [120]. A randomized control trial compared CEM and MTA for pulpotomy treatments, which showed no significant differences in apexogenesis (root closure) radiographically after 12 months follow up [121]. However, Azimi et al. (2014) [122] performed a comparative study between MTA and bioceramic paste, where no statistically significant result was seen when evaluating the inflammatory response or hard tissue formation between both the materials after Cvek's pulpotomy [122]. In one systematic review, the studies selected compared MTA with $\mathrm{CaOH}$ and tricalcium silicate and tested for their success rate, inflammatory response, and dentin bridge formation. They evaluated 46 studies and showed that MTA (odds ratio: 2.72) had a significantly higher success rate in all aspects when compared to $\mathrm{CaOH}$. On the contrary, no noticeable difference was seen between MTA and tricalcium silicates (odds ratio 1.18) [123]. In another systematic review by da Rosa et al. (2018) [124], they compared over 716 papers and 83 patents, which mainly studied $\mathrm{CaOH}$, followed by MTA. The study concluded that MTA surpassed $\mathrm{CaOH}$ in all aspects and was favourable for pulp regeneration [124]. MTA and Biodentine ${ }^{\mathrm{TM}}$ were also compared by Celik et al. (2019) [125] as pulpotomy agents in pulp-exposed carious teeth. Their results show a $100 \%$ radiographic success rate after 24 months for MTA and $89.4 \%$ for biodentine ${ }^{\mathrm{TM}}$ [125]. It is evident from these studies that, although the literature has a lot of evidence and data on the biomimetic properties of each biomaterial discussed here, it is still inconclusive when it comes to individual clinical implementation. Success in clinical dentin-pulp preservation or regeneration depends on the tooth, type of carious lesion, and pulp injury. 


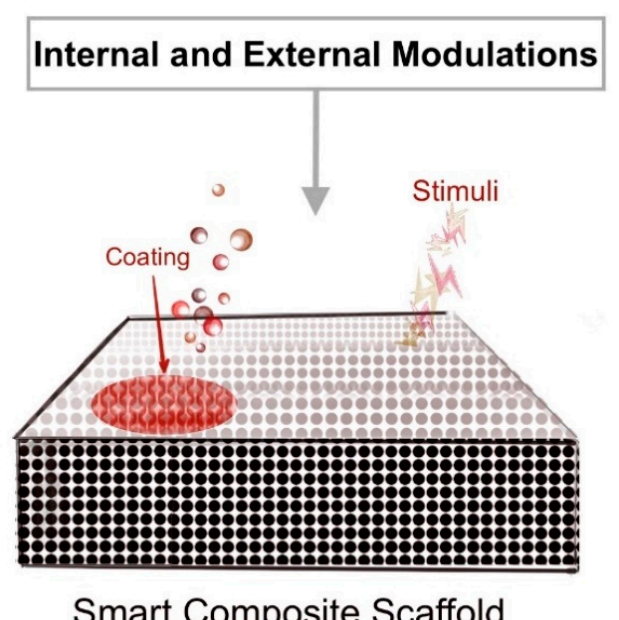

Figure 3. Smart scaffolds for dentin pulp regeneration. Image adapted from Perez et al. [118] and Moussa et al. [119].

Although we have developed some highly bioactive and biocompatible materials as medicaments and scaffolds for dentin and pulp repair and regeneration, there is still a need to simultaneously organize both biological and mechanical aspects of these biomaterials. Our primary goal is to induce appropriate signalling pathways for cell-cell and cell-matrix interactions while being noncytotoxic to cells with superior mechanical properties that will mimic in vivo conditions to engineer the dentin pulp complex. Researchers should focus on developing tailor-made biomimetic analogues while keeping in mind the essentials of dentin pulp regeneration, including revascularization, cell, differentiation, and growth factor integration with the ability to induce good quality remineralisation of hard tissues.

\section{Biomimetics in Oral and Maxillofacial Regeneration}

\subsection{Biomimetics in Bone Regeneration}

\subsubsection{Bone, a Complex Hub, and a Multitasker}

Bone is a highly specialised, complex, and dynamic part of the skeletal system. Apart from the major function of providing a framework for all the tissues, it is inherently involved in maintaining several physiological activities, namely haematopoiesis, regulation of ions, maintenance of muscle mass, and a lot more. It can be classified in two forms: trabecular (medullary) and compact bone (cortical), both having separate and distinct functions. Trabecular or spongy bone, as its name suggests, has larger pore size to accommodate hematopoietic cells and comprises the bone marrow, while cortical bone has more osteocytes and is involved in responding to mechanical signals by bone remodelling (mechanotransduction) [126-128]. Cortical bone is highly dense (less than $20 \%$ porosity) and composed of closely knit osteons which concentrically form cylindrical systems known as Haversian system, lodging a blood vessel in the centre (Figure 4). This system has anisotropic mechanical properties, with the modulus of elasticity $(\mathrm{E})=20 \mathrm{GPa}$ along the Haversian system and $\mathrm{E}=8 \mathrm{GPa}$ along the transverse axis, thus providing a rigid structure $[129,130]$. On the other hand, cancellous bone has $>90 \%$ porosity and is arranged into plates (trabeculae), which offers a larger surface area to mass ratio and better flexibility with $\mathrm{E}=100 \mathrm{MPa}$ [131]. Furthermore, bone comprises organic and inorganic components (collagen-hydroxyapatite matrix) that provide an interplay of elasticity and rigidity, respectively [132]. Increase in the collagen mineralisation increases the modulus of elasticity, which makes it possible to bear more stress. In contrast, pure collagen carries the capacity to bear deformation [133]. Furthermore, bone organization and regeneration by requisition of different molecules like collagen and growth factors are facilitated by extracellular components like glycosaminoglycans (GAGs) or proteoglycans (PGs) and by gap junctions [128,134]. 


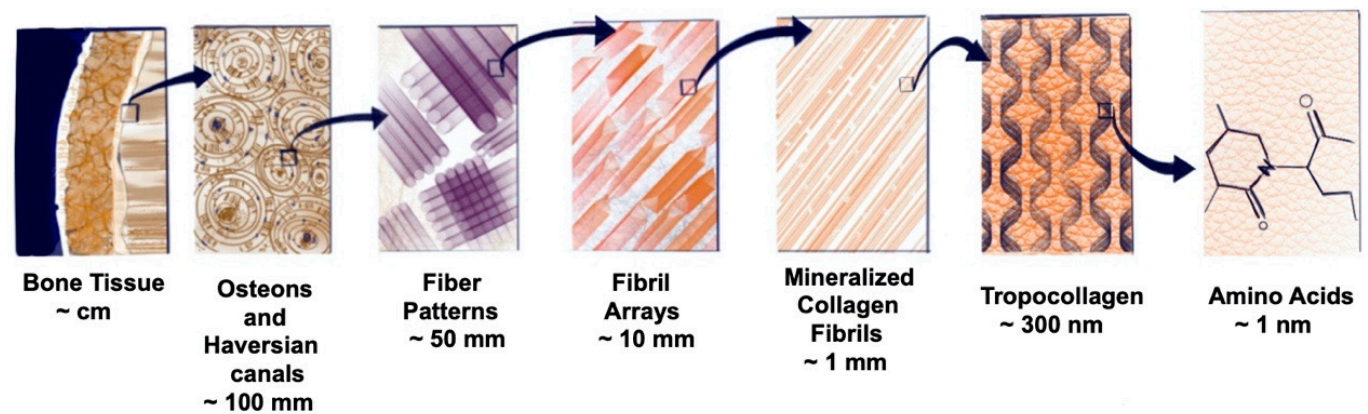

Figure 4. Macro- and microstructural arrangement of bone: the macroscale structure comprises of dense outer compact bone and spongy inner cancellous bone. Compact bone is arranged into osteons that form haversian canals. These osteons are formed by fibres arranged in geometrical patterns. These fibres are made up of collagen fibrils which have alternating organic phases to form fibril arrays. Each array makes up one collagen fibre. Collagen consists of protein molecules (tropocollagen) formed from three chains of amino acids. Image adapted from Launey et al. [135].

Bone has a regenerative capacity of its own and can heal without scarring in case of an uneventful healing. However, in cases with large or critical sized defects, it requires additional support and stabilisation for healing and regeneration. Hard tissue defect's aetiology in the orofacial region can be attributed to genetic or congenital malformations, trauma, infections, cancer, and several other systemic or local pathologies. In oral surgery, its application extends from minor defects like periodontal pockets to moderate bone abnormalities like maxillary sinus lift and to much larger bone defects like mandibular and craniofacial reconstruction. Given the demand, bone regeneration is of primary importance in this field and bone is the second most transplanted tissue after blood. Extensive preclinical research has been done in this regard, with only a few therapies making it to the clinics [136]. Thus, it is highly imperative to look for the most efficient and beneficial ways of bone regeneration while ensuring the integrity and maintenance of the surrounding tissues and its functions. In this section, we will discuss the ideal requirements for regenerative therapies that will ensure highest biological function of the regenerated tissue, highlighting the past and current developments in the field.

\subsubsection{Determinants of Biomimetics for Bone Regeneration}

The prerequisite for biomimetic regenerative therapies is having complete knowledge of the tissue to be worked with. Given the high complexity and multifunctionality of bone, the standard for regenerative therapies is set high. The biologically active agents that aid in bone regeneration should ensure adhesion, migration, proliferation, and differentiation of osteoprogenitor cells, thus resulting in an acceptable osseointegration. Moreover, considerations for optimal ECM and blood vessel formation are required for a satisfactory result.

(A) Mechanical and compressive strength: Human cortical bone and cancellous bone compressive strength ranges from 90-230 MPa and 2-45 MPa, respectively [137]. The compressive and tensile strength, and the density and fracture toughness of the graft should be comparable to that of the recipient site. Moreover, it has been shown that the scaffolds' stiffness can have a direct effect on the behaviour of the surrounding cells [138]. Therefore, it becomes critical to choose the material according to the site of procedure and the desired outcome.

(B) Surface properties: Surface differences, even at nanoscale ranges, can affect the behaviour of cells. They have a regulatory effect over several osteoblastic functions like cell adhesion, migration, proliferation, cell signalling, genetic expression, and stem cell fate. It is attributed to properties like increased surface area and roughness; increased wettability and porosity, which in turn increases nutrient exchange; and protein absorption [139].

(C) Pore size: It is a critical determinant in bone regeneration and repair as it allows for easy exchange of bone and blood cells, along with other nutrients within the bone. Natural grafts have the 
advantage of inherently possessing the ideal pore size, while several parameters are considered in fabricating synthetic graft materials. The pore size recommended previously was $0.3 \mathrm{~mm}$ to $0.5 \mathrm{~mm}$ to allow proper vascularization and osteogenesis. Pamula et al. used a poly-L-lactide-co-glycolide (PLG) scaffold with equal pore density but different pore size. Biocompatibility was measured by comparing the penetration of osteoblast-like cells and the expression of bone reforming proteins like osteopontin and osteocalcin. The growth and penetration were seen more with pore size $0.4 \mathrm{~mm}$ to $0.6 \mathrm{~mm}$, indicating that a larger pore size than recommended before is favourable for osteogenesis [140]. Ghayor et al. demonstrated that material with a pore size of the range 0.7 to $1.2 \mathrm{~mm}$ performed better in in vivo models for calvarial defects [141].

(D) Controlled biodegradability and dimensional stability: Most commonly, the grafts should be absorbed and replaced by natural tissue over time. Therefore, it requires the material to have intermediate biodegradability, which corresponds to the simultaneously ongoing natural remodelling process [142]. If the graft resorbs prematurely, there is a possibility of graft collapse within the defect and eventually failed restoration. On the other hand, delayed resorption can interfere with natural bone deposition, elicit immunogenic reactions, and thus decrease biocompatibility. In general, a decrease in particle size and an increase in porosity of biomaterials reduce the mechanical strength and enhance the biodegradation rate. Also, nanomaterials undergo faster and more homogenous biodegradation than conventional micron-based materials. Predictably, biphasic and composite materials exhibit degradation rates intermediate between the two depending on the percentage of each phase. For example, Hydroxyapatite (HA)-based materials have a very low degradation rate, while tri-calcium phosphate (TCP) and organic grafts have higher. Thus, biphasic (HA + TCP) grafts have to be used with special consideration for the type of recipient site and its degradation profile [143]. Good dimensional stability allows for chairside adaptation of the bone graft to the defect.

(E) Biocompatibility: For a graft to be biocompatible, it should allow growth, differentiation, and attachment of osteogenic cells and have antimicrobial and appropriate inflammatory properties. Inflammatory responses to some extent aid in the integration of the graft or implant material as it leads to remodelling of the tissues by enhancing angiogenesis, by removing debris generated during the surgical procedure, and by enhancing chemotaxis of reparative cells including pluri-/multipotent cells [144]. Some materials need to get resorbed by the natural host response mechanisms, while others which have to be implanted for longer terms require degradation just enough to ensure high tissue integration. Thus, different levels and extent of inflammatory response are desired depending on the purpose of the regenerative procedure [145]. Furthermore, in Anthony Gristina's language, successful osseointegration is a "race for the surface" between microbial colonization and tissue cell integration [146]. Harnessing the antimicrobial response is critical to ensure successful graft, further discussed in the following periodontology section.

\subsubsection{Bone Grafts and Scaffolds}

(A) Natural grafts

(i) Autograft: It is a part of the patients' own tissue and has been considered the gold standard for bone defect repair for years $[147,148]$. They are commonly obtained from the iliac crest, parietal bone, and mandible. However, it becomes critical to have a second surgical procedure at the tissue harvest site, which increases the risk of developing morbid complications such as donor site injury, deformity, and scarring. It is also associated with higher costs for the surgical procedure, longer recovery times, excessive bleeding, pain, inflammation, and occasionally infections. However, they have a limited role in restoration of larger defects, which requires a higher amount of bone. The issues mentioned above have made other graft materials as a more lucrative alternative in clinical practice [149].

Another exciting autologous bone graft procedure is by ectopic prefabrication, where heterotopic ossification is achieved to produce bone tissue by placing a scaffold in vivo. It utilises the principle of Wolf's law, according to which muscles and bones mechanically and functionally perform together and have an organizational effect upon one another [150]. Wang et al. successfully demonstrated the 
fabrication of mandibular bony construct by placing a mandible-shaped titanium mesh scaffold packed with cancellous autologous blocks from dog ribs into the latissimus dorsi muscle with thoracodorsal artery and vein through the scaffold [151]. Similar studies have been done by Kokemüller et al. (2014), Naujokat et al. (2019), and Warnke et al. (2004). This method of bone regeneration seems promising, with an excellent review by Huang et al. [152].

(ii) Allografts include grafts taken from living donors or cadavers and are the second most commonly used bone grafts [153]. They offer similar advantages as autografts and can be harvested as various bone matrices: cancellous chips, cortico-cancellous grafts, cortical grafts, osteochondral, and whole bone segments. However, they have a higher risk of developing immune reactions due to mismatched genetics. Additionally, there is a risk of transmission of infection. Therefore, the grafts are devitalised through decalcification, deproteinization, irradiation, and freeze-drying procedures for preservation. The aforementioned processing makes the osteoinductive potential negligible as the cells are lost. Blume et al. recently used an allograft to fabricate a customized bone graft using CAD/CAM technology which fit the large defect perfectly and thus was a clinical success [154].

(iii) Xenografts: Xenografts are any graft across different species. They offer similar advantages and drawbacks like the allografts, but the immunogenicity is expected to be higher along with higher risk of cross-species infection. Interestingly, the phenomenon is seen to be lesser with these grafts, and thus, they have emerged as promising candidates as transplant material $[155,156]$. Decellularized Bone (DCB) remains the most common graft material. Recently, growth factor-enhanced DCB has been developed. Also, the addition of doxycycline to Bovine Hydroxyapatite (BHA) was observed to be more stable than the graft without it, due to its nonantibiotic effects on fibroblasts, mesenchymal cells, and osteogenic cells, which promote cell adhesion and, ultimately, cell proliferation and differentiation [157]. Notable FDA-approved DCB products include Graftech ${ }^{\circledR}$, GraftCage ${ }^{\circledR}$, BTB Select ${ }^{\circledR}$, BioCAP Select ${ }^{\mathrm{TM}}$, MatriGRAFT ${ }^{\circledR}$, and ReadiGRAFT ${ }^{\circledR}$ [158]. A summary of all the natural grafts is given in Table 6.

Table 6. Different types of natural bone grafts.

\begin{tabular}{|c|c|c|c|}
\hline Type of Graft & Action & Advantage & Disadvantage \\
\hline Ectopic prefabrication & $\begin{array}{l}\text { Osteogenic } \\
\text { Osteoinductive } \\
\text { Osteoconductive }\end{array}$ & $\begin{array}{c}\text { Histocompatible } \\
\text { Negligible immunogenicity } \\
\text { Ideal physical and mechanical properties } \\
\text { No shape or volume limitation }\end{array}$ & $\begin{array}{l}\text { Donor site injury } \\
\quad \text { Scarring } \\
\text { Longer recovery time }\end{array}$ \\
\hline Allografts & $\begin{array}{c}\text { Osteogenic } \\
\text { Osteoconductive }\end{array}$ & $\begin{array}{l}\text { Histocompatible } \\
\text { Ideal physical and mechanical properties. }\end{array}$ & $\begin{array}{c}\text { Immune reaction } \\
\text { Transmission of infection }\end{array}$ \\
\hline Xenografts & $\begin{array}{c}\text { Osteogenic } \\
\text { Osteoconductive }\end{array}$ & $\begin{array}{l}\text { Histocompatible } \\
\text { Ideal physical and mechanical properties. }\end{array}$ & $\begin{array}{c}\text { Immune reaction } \\
\text { Transmission of infection }\end{array}$ \\
\hline
\end{tabular}

(B) Natural polymers.

A diverse group of naturally occurring substances represent the constitution of the extracellular matrix (ECM). Thus, they can be used as scaffolds for bone regeneration with or without the combination of stem cells and growth factors, more commonly employed in a technique called guided bone regeneration (GBR). A few of the polymers, as described by Haugen et al., can be classified as proteins (collagen, gelatin, and fibrinogen, elastin); polysaccharides (glycosaminoglycans, cellulose, and amylose); and polynucleotides (DNA and RNA) [136].

(i) Autologous ECM-based substitutes: Comparable performance of decellularized allogeneic and xenogeneic bone grafts to autogenous bone grafts indicates the importance of ECM in bone. Paduano et al. examined in vitro osteogenic induction of dental pulp stem cells (DPSCs) by culturing them on decellularized bone matrix (bECM) as well as collagen type 1 matrix (Col-1). bECM with 
osteogenic growth factors showed maximum expression of osteo-specific markers as compared to the Col-1 matrix [159].

(ii) Proteins: Collagen, elastin, fibrinogen are some of the abundant extracellular matrix proteins. Scaffolds derived from these can be manufactured to simulate natural ECM and, when used with integration of growth factors or living cells, can offer osteoconductive and osteoinductive properties [160]. More recently, bioinspired proteins have gained attention as biomimetic scaffolds for hard tissue regeneration [161].

(iii) Marine products: They offer a possible source of bone substitutes as they can mimic bone with their biochemical composition, structural arrangement, and biofouling ability [162]. Marine products include collagens from jellyfish, polymers from marine diatoms, chitin from marine sponges, and hydroxyapatite and calcium phosphates from fishbone and other organisms. [163,164] Sensing the osteogenic potential of marine products, Pinctada's powdered nacre was used for maxillary augmentation by Atlan et al. as early as 1990, while recently, Coringa et al. studied bone substitutes from oysters in mandibular defects in an animal model [165]. Advances have been made for chemical modification of marine products and their use as scaffolds for pluripotent cells' culture [166]. Chitosan, a polymer initially derived from marine organisms, is now widely studied for bone regeneration [167,168].

(C) Synthetic graft materials

(i) Bioceramics:

Ceramic scaffolds are derived from bioactive inorganic materials. They offer the advantage of providing a similar biochemical composition of the inorganic phase of natural bone tissue. Most commonly, Calcium phosphate (CaPs)-derived scaffolds are used, amongst which most popular are hydroxyapatite (HA) and tricalcium phosphate (TCP). CaPs have the ability for osteoconduction by allowing osteoblasts to attach, proliferate, and differentiate [169]. On several occasions, CaPs have been seen to have osteoinductive effects as well [170]. This is attributed to the topography, porosity (both size and saturation), and composition of these materials, which are believed to allow adsorption, entrapment, and the final concentration of circulating osteogenic factors and osteoprogenitor cells. HA and TCP are usually used as biphasic composites (BCP). HA is insoluble and thus maintains the space and structure, while TCP stimulates new bone formation by the dissolution of calcium and phosphate ions. Nevins et al. tested different compositions of BCP for alveolar ridge modification, where similar results were obtained for all, with the only difference being graft resorption. It was delayed by increasing the amount of HA, which is expected [171]. Janssen et al. used microstructured TCP in glycerol matrix in cleft palate repair as an alternative to autologous grafts and found them satisfactory [172]. It can be further highlighted that the origin and method of synthesis of these scaffolds can have a direct impact on the cellular responses. Marinucci et al. reported higher osteogenic induction with bovine-derived HA than HA alone when the genetic profiles of mesenchymal stem cells were compared [173]. Similar comparative studies have been done, which indicate that, even if the broader outcomes seem similar, there are differences in minute cellular responses which might cause differences in the regenerative potential and effect of a graft [174]. This variability can be attributed to the difference in their dissolution/precipitation behaviour, microporosity, physicochemical properties, surface area, and topography [175]. Thus, the graft materials have to be thoroughly studied and carefully selected for the intended purpose.

Bioactive glasses that contain calcium can produce a bioactive hydroxy carbonated apatite layer in biological fluids that can be biologically integrated into the tissues [176]. Further, their resorption rates can be customized to make it possible to release bioactive molecules at a controlled rate. Although the brittleness of these materials is a concern, efforts are being made to produce a scaffold of comparable mechanical properties to that of bone [177].

(ii) Synthetic polymers: For bone regeneration, the most commonly used polymers are aliphatic polyesters poly-lactic acid (PLA), poly-lactide-co-gylcolide (PGLA), poly-e-caprolactone (PCL), polyhydroxyalkanoates (PHA), polyglycerol sebacate (PGS), and poly-glycolic acid (PGA) [178]. 
They have tuneable biomechanical, biodegradability, and structural properties. Nevertheless, they have limited osteoconduction as they have low cell attachment capacity [178]. Also, they are mechanically stiff, which contradicts the flexibility of natural bone. To overcome the brittleness of bio-ceramics and stiffness of polymers, composite polymers have been widely explored [179]. Collagen-HA was considered as a promising candidate. Eventually, biomimetic mineralised collagen (MC) was introduced [180]. Feng et al. showed that MC gave better clinical outcomes for socket preservation than collagen-HA [181].

(D) Applications and advances

(i) Micro-/nanofibres and nanoparticles

These are produced through electrospinning, which enables the manufacture of extracellular matrix (ECM)-like structures. They have high porosity, specific surface area, and nano-topography, modulating cellular behaviour to promote cell adhesion, proliferation, and differentiation by mimicking the ECM. Several recent studies have reported the differentiation of Mesenchymal stem cells (MSCs) and other multipotent cells into mineralising osteoblasts when cultured on electrospun nanofibres [182,183]. Electrospun PCL scaffold was used by Puwanun et al. to assess the differentiation of mesenchymal stem cells from jaw and periosteal tissue [184]. Although clinical studies with nanofibres in dentistry are still emerging, one of the clinical trials with nanohydroxyapatite was done by Lombardi et al. Mean sinus pneumatization was significantly lesser $(p=0.15)$, and crestal bone resorption was less as well ( $p=0.24)$, indicating the potential role of these therapies in socket preservation after molar, especially third molar extraction [185].

(ii) Nanocomposites

Nanoscale features have a regulatory effect over profuse osteoblastic cellular functions like cell adhesion, migration, proliferation, cell signalling, genetic expression, and stem cell fate. Zhang et al. reported the nanohydroxyapatite's compressive strength (poly-l-lactic acid nanocomposites), which was greatly enhanced and reached $115 \mathrm{MPa}$, comparable to natural bone [186]. Nanohydroxyapatite-covered polyhydroxy butyrate (PHB) fibres obtained through electrospinning showed better results than simple PHB scaffolds [187]. Biocompatible nanocomposite with polyurethane, chitosan, and TCA was fabricated and loaded with amoxicillin, which offers a promising approach for bone tissue engineering [186,188].

Similarly, drug loading can be enhanced using nanocomposites to elicit drug delivery, most commonly needed for anti-inflammatory and antibiotic effects. Recently, Shi et al. fabricated a novel twin-fibre membrane with antibacterial and osteoinductive properties. The drug's slow release matched with natural bone regeneration, and the material proved to be biocompatible and had improved osteogenic properties. It can serve as biomimetic multifunctional artificial periosteum, the natural layer responsible for bone regeneration [189]. Similarly, a composite scaffold with PLA, PCL blended with nanoHA, and cefixime complex was synthesized by Sharif et al. with potential application in oral and maxillofacial related therapies [190].

In conclusion, most widely used bone substitutes in dentistry are still naturally derived grafts and natural polymers in combination with bio-ceramics. Several recent clinical trials are listed in Table 7. In a metanalysis study of bone graft substitutes, Corbella et al. found that autogenous bone (AB) alone leads to significantly higher osteogenesis in comparison to Bovine bone (BB) $(p=0.04)$ In contrast, no significant difference was found when $\mathrm{BB}$ was compared with a mixture of $\mathrm{AB}$ and $\mathrm{BB}(p=0.52)$ [191]. Moreover, BB showed higher bone formation than HA alone $(p<0.001)$, but a mixture of HA with TCP showed better results than BB $(p<0.001)$ [191]. In another metanalysis, Jensen et al. showed that synthetic bone grafts showed significantly less clinical outcomes [192]. Thus, natural and biologically closer substitutes offer higher clinical success [192]. 
Table 7. Maxillary sinus lift using different bone grafts in oral and maxillofacial surgery.

\begin{tabular}{|c|c|c|c|c|c|}
\hline Ref. & Type of Study & Type of Graft & Method of Evaluation-In Vitro/In Vivo & Sample Size & Conclusions \\
\hline [193] & $\begin{array}{l}\text { Randomized clinical trial } \\
\text { (NCT03496688) }\end{array}$ & $\begin{array}{c}\text { MCBA } \\
\text { FDBA } \\
\text { ABB } \\
\text { EB } \\
\text { HA-TCP-30/70 } \\
\text { BC } \\
\end{array}$ & Histological and histomorphometric analysis & 6 patients & $\begin{array}{l}\text { All materials showed good biocompatibility and Osseo } \\
\text { conductivity with FDBA as the best material, but only one patient } \\
\text { per sample was used, so a larger sample size is required. }\end{array}$ \\
\hline [194] & $\begin{array}{l}\text { Randomized split-mouth } \\
\text { study (NCT03682315) }\end{array}$ & $\begin{array}{c}\mathrm{ACB}+\mathrm{ABB} \\
\mathrm{ACB}+\mathrm{BP}\end{array}$ & $\begin{array}{l}\text { Radiographic analysis, mRNA analysis, } \\
\text { histopathological analysis, } \\
\text { Immunohistochemistry, TEM } \\
\end{array}$ & 8 patients & $\begin{array}{l}\text { Biphasic psychogenic biomaterial (BP) induced a higher } \\
\text { radiographical vertical resorption and graft collapse in comparison } \\
\text { with the combination with an organic bovine bone (ABB). }\end{array}$ \\
\hline [195] & Randomized clinical trial & DPBM vs. DBBM & $\mathrm{CT}$ and trephine biopsy histology & $\begin{array}{l}11 \text { participants for PPA, } \\
12 \text { ITT }\end{array}$ & $\begin{array}{l}\text { Porcine bone (DPBM) showed comparable results with the widely } \\
\text { used bovine bone (DBBM). A larger sample size and more } \\
\text { extended studies are still required. }\end{array}$ \\
\hline [196] & Randomized clinical trial & $\begin{array}{l}\text { MBS } \\
\text { BBS }\end{array}$ & $\begin{array}{l}\text { Histological } \\
\text { Histomorphometric } \\
\text { CBCT }\end{array}$ & 60 patients & $\begin{array}{l}\text { BBS remains more stable in terms } \\
\text { of volume maintenance and radiological graft homogeneity after a } \\
\text { healing period of } 6 \text { months. }\end{array}$ \\
\hline [197] & Randomized clinical trial & $\begin{array}{l}\text { Calcium phosphate crystal double- } \\
\text { coated bovine bone and an organic } \\
\text { bovine bone }\end{array}$ & $\begin{array}{l}\text { Histological } \\
\text { Histomorphometric } \\
\text { radiographic }\end{array}$ & 33 patients & $\begin{array}{l}\text { Both materials showed comparable histomorphometric and } \\
\text { radiographic results. }\end{array}$ \\
\hline [198] & $\begin{array}{l}\text { Randomized split-mouth } \\
\text { study (NCT03077867) }\end{array}$ & $\begin{array}{l}\text { NHA } \\
\text { ABB }\end{array}$ & Histomorphometric & 28 patients & $\begin{array}{l}\text { After six months of healing, no statistically significant difference } \\
\text { was present in histomorphometric outcomes between the NHA } \\
\text { and ABB groups. }\end{array}$ \\
\hline
\end{tabular}

Mineralised solvent-dehydrated bone allograft (MCBA), freeze-dried mineralised bone allograft (FDBA), anorganic bovine bone (ABB), equine-derived bone (EB), synthetic micro-macroporous biphasic calcium-phosphate block consisting of 70\% beta-tricalcium phosphate and 30\% hydroxyapatite (HA-TCP 30/70), or bioapatite-collagen (BC); Bio-Oss ${ }^{\circledR}$ Spongiosa (Autogenous cortical bone (ACB) + Autogenous Bovine Bone (ABB)) Symbios ${ }^{\circledR}$ Biphasic BGM (ACB + Biphasic psychogenic(BP)); Transmission Electron microscopy (TEM); Deproteinized porcine bone mineral (DPBM), demineralised bovine bone mineral (DBBM), Per-protocol analysis (PPA), Intention to treat analysis (ITT); monophasic bone substitute (100\% ß-TCP) (MBS); a biphasic bone substitute (60\% HA and 40\% B-TCP) (BBS); Pure sintered nanohydroxyapatite (NHA); and anorganic bovine bone (ABB). 


\subsubsection{Cell Therapy}

(A) Stem cells

Cells, either tissue-specific or multipotent, have an immense role in tissue engineering research, both in vivo and in vitro, and for treatment as well as testing for different grafts/scaffolds. Variations in the studies call for standardized cell models that can be reproducible in all the settings. Palumbo et al. compared the behaviour of committed human osteoblast cells from bone biopsies with multipotent human dental pulp cells (hDPSC) from extracted teeth to identify cellular models for bone regeneration. They found that committed osteoblast cells are useful for identifying and testing materials and surfaces osseointegration while hDPSCs are more useful for obtaining in vitro osteocyte-like network for bone regeneration [199]. Having established the cell models, there have been numerous studies regarding cell therapies. For bone regeneration, a wide range of pluripotent stem cells have been studied in oral and maxillofacial surgery, human umbilical cord mesenchymal stem cells [200], bone marrow-derived stem cells [201], adipose-derived stem cells [202], mesenchymal dental pulp stem cells [203,204], periodontal ligament stem cells [205], and SHED [206]. While the wide use of these cells seems promising, strict vigilance and regulation is required to ensure standardized treatment outcomes. Given the unpredictable nature of multipotent and pluripotent cells, stem cell-derived conditioned media are getting more attention $[199,207,208]$.

(B) Hybrid scaffolds

CaP-based scaffolds, as discussed above, are osteoinductive due to their nurturing nature towards the cells and accommodation for growth factors. To potentiate the osteoinductive capacity, scaffolds integrated with osteoprogenitor cells and factors were developed [204,209,210]. Korn et al. studied substitutes for autologous grafts in rodent models for alveolar cleft alveoloplasty using bHA alone, bHA with undifferentiated MSC, and bHA with osteogenically differentiated MSCs, where the last group showed the best bone growth [211]. Strontium folate (SrFO) derivatives were integrated into biohybrid scaffolds given their role in treating osteoporosis and other bone diseases. Martin-del-Campo et al. loaded the SrFO derivatives in TCP and chitosan polyethylene dimethacrylate scaffolds, which were then seeded with DPSCs. They observed significantly improved results with SrFO-integrated scaffolds in terms of bone formation [212]. In a clinical study by Al Ahmady et al., autologous bone marrow mononuclear cells combined with platelet-rich fibrin and nanohydroxyapatite were used to treat alveolar cleft. It led to lesser donor site complications, faster soft tissue healing, and less postoperative pain [213].

\subsubsection{Cell-Free Therapies}

Bone healing is a complex and highly coordinated process, generally divided into inflammation, renewal, and remodelling (Figure 5). Mimicking this process by using the appropriate growth factors and small molecules in a regenerative field can help achieve a successful clinical outcome [214]. Furthermore, these growth factors are also responsible for the recruitment and maturation of osteoprogenitor cells, especially mesenchymal stem cells. Therefore, they can perform on-site programming of the cells [215]. 

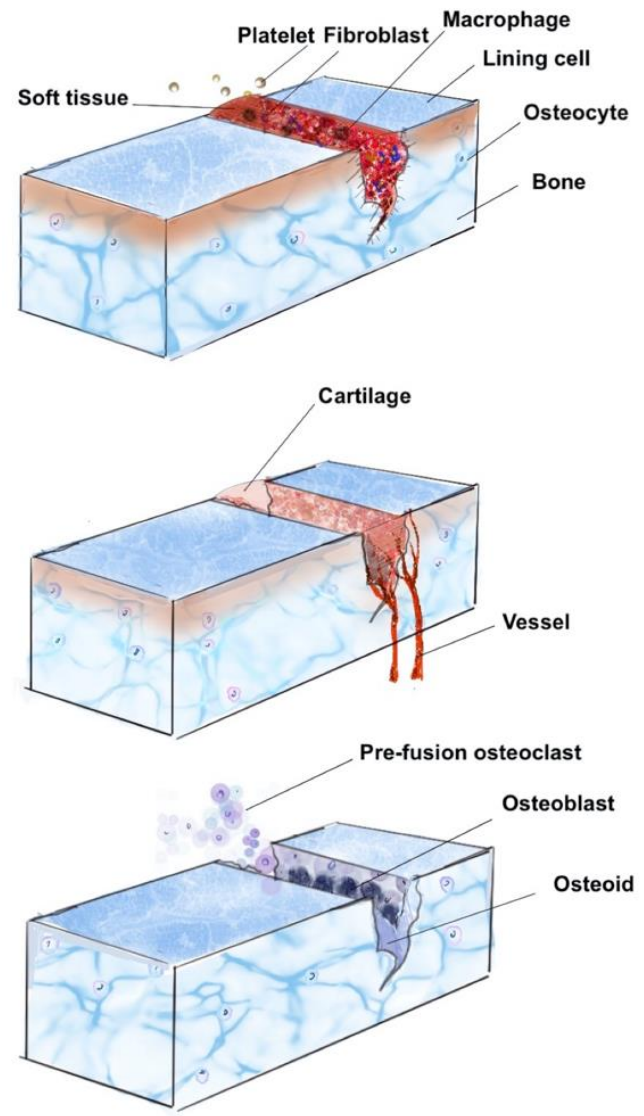

A.Inflammatory phase

Inflammation: CCL-2, TGF - $\beta$, IL-1, IL - 6, M - CSF

Recruitment of MSCs: PDGF - BB, TNF- $\alpha$, SDF -1, BMP -2, BMP-4, BMP-5, BMP-6

\section{B.Soft Callus formation}

Angiogenesis: Ang-1, Ang-2, VEGF-A, FGFs, PDGFs, PIGFs, BMPs, FGF-2

Chondrogenesis \& matrix production: TGF- $\beta$, IGF -1, FGFs, BMPs, GDF-5, PDGF-BB

\author{
C.Mineralization / Resorption of the callus / Bone \\ remodelling
}

\section{Angiogenesis: VEGFs}

Cartilage resorption: M-CSF, OPG, RANKL, TNF- $\alpha$ MSCs differentiation and bone deposition: BMPs, Wnt ligands

Bone resorption: RANKL

New bone formation: BMP-2, PTH, IGF-1, Wnt ligands

Figure 5. The temporal progression of fracture healing: healing of a fracture involves a complex series of processes which can be broadly divided into four phases, A. inflammatory phase; B. soft callus formation, C. mineralisation of callus, and bone remodelling. Each phase is regulated by key growth factors, as shown in the figure. $\mathrm{BMP}=$ bone morphogenetic protein, FGF = fibroblast growth factor, GDF-5 = growth/differentiation factor 5, IGF-1 = insulin-like growth factor 1, M-CSF $=$ macrophage colony-stimulating factor, $\mathrm{OPG}=$ osteoprotegerin, $\mathrm{PDGF}=$ platelet-derived growth factor, $\mathrm{PlGF}=$ placental growth factor, $\mathrm{PTH}=$ parathyroid hormone, $\mathrm{RANKL}=$ receptor activator of nuclear factor $\mathrm{\kappa B}$ ligand, SDF-1 = stromal cell-derived factor 1 , TGF- $\beta=$ transforming growth factor $\beta$, TNF- $\alpha=$ tumor necrosis factor $\alpha$, and VEGF $=$ vascular endothelial growth factor. Image adapted from Yague et al. [216].

(A) Bone morphogenetic protein (BMP)

It has emerged as the most promising medium for bone regeneration $[217,218]$. Sudheesh et al. studied a biphasic polycaprolactone construct combined with hyaluronic acid-based hydrogel and loaded with BMP-2 for correction of vertical bone height in the mandible in rabbits. The outer wall of the biphasic material simulated cortical bone, while the core simulated medullary bone. BMP was released in a sustained manner from the construct, while it provided mechanical and space maintenance properties through the cortical part and osteogenesis and angiogenesis through the medullary [219]. Gene delivery is also a lucrative method as it ensures prolonged and stable production of the protein, reviewed by Park et al. for BMP2 in dentistry [220]. In a meta-analysis for animal studies for gene delivery in maxillofacial bone defects, Fliefel et al. found gene delivery as better therapeutics [221].

(B) The vascular endothelial-derived growth factor (VEGF), and IGF1 and 2

The VEGF pathway is considered critical for angiogenesis, which indirectly affects osteogenesis [222]. VEGF acts synergistically with BMP and other growth factors [223]. Kim et al. used FGF with BMP2 to show improved maxillary alveolar bone regeneration [224]. FGF in low concentration is seen to improve osteogenesis. Kitamura et al. tested its clinical potential in an RCT and successfully treated patients with 
periodontal defects [225]. IGF 1 and 2 have roles in osteoblast differentiation, stimulation of bone matrix deposition, and collagenous and non-collagenous protein expression and thus was tested for osteogenic differentiation of MSCs by Reible et al. [226].

(C) Platelet-derived growth factor (PGDF)

PGDF promotes osteogenesis as well as angiogenesis and has been shown to be successful in periodontal tissue regeneration [227]. In a systematic review by Li et al., BMP was concluded to be less effective than PDGF [228]. A rich source of growth factors is platelet-derived products like Platelet-rich plasma (PRP) and Platelet-rich fibrin (PRF). PRP is recommended for faster delivery and PRF for the stable delivery of factors [229]. Recently, Stumbras et al. performed alveolar ridge preservation using bone substitutes and autologous platelet concentrate, where they found that plasma-rich growth factors perform better than the grafts [230]. Concentrated growth factor (CGF) has also emerged as an excellent tool for oral regenerative medicine [231,232].

\subsection{Biomimetics in Mucosal Repair}

\subsubsection{Oral Mucosa}

Oral mucosa is one of the most forgiving tissues in our body, which heals rapidly and without scarring, usually in smaller defects. It can be attributed to increased vascularity and faster turnover rates. Oral mucosa is a highly specialised tissue which is divided into alveolar and masticatory mucosa, depending on the site and function. Their healing becomes challenging in case of large defects where open wounds remain susceptible to infection and wound contracture. In these conditions, grafts are required to cover up the wound site to make up for the lost tissue and to act as barriers to ensure uneventful healing by preventing foreign body entrapment (dead cells and debris) and infection. Grafts for oral mucosal repair become challenging as it is constantly under wet environment due to oral fluids and is introduced to load due to mastication and food.

\subsubsection{Determinants of Biomimetics}

Regenerated tissues are inevitably required to mimic the complex organization of mucosal layers to have an uneventful and successful wound healing. The desired outcomes for successful biomimicry are organization into multiple functional layers with ECM organization, maintenance of functionality, exhibition of volume stability, creation of an epithelial barrier, biocompatibility, lack of toxicity, and immunological rejection $[233,234]$. The regenerated tissues are inevitably required to mimic the complex organization of the mucosal layers to have uneventful and successful wound healing.

\subsubsection{Mucosal Grafts}

(A) Autologous grafts till today remain the gold standard. Conventional techniques that are still most widely used include local flaps, distal flaps, and free vascularized flaps from a donor site. However, their limitation in large defects and donor site morbidity leads to the search for new regenerative scaffolds and tissues. Cell culturing techniques for autologous cell sheet formation offer advantages of an autologous graft without the donor site's involvement. Keratinocyte-based products are the ex vivo produced oral mucosal equivalent (EVPOME), which are constructed by cultivation of autogenous keratinocytes [235]. Amemiya et al. have done tremendous work over the years to develop autologous graft cultures over the human amniotic membrane, with a successful clinical trial done recently (Figure 6) [236]. Fibroblast-based constructs involve culture of embryonic fibroblasts or autologous fibroblasts, which are cultures over a collagen matrix. The scaffold resorbs upon transplantation, leaving the ECM and functional fibroblasts which secrete appropriate growth factors, allowing faster healing of the tissue [237]. 

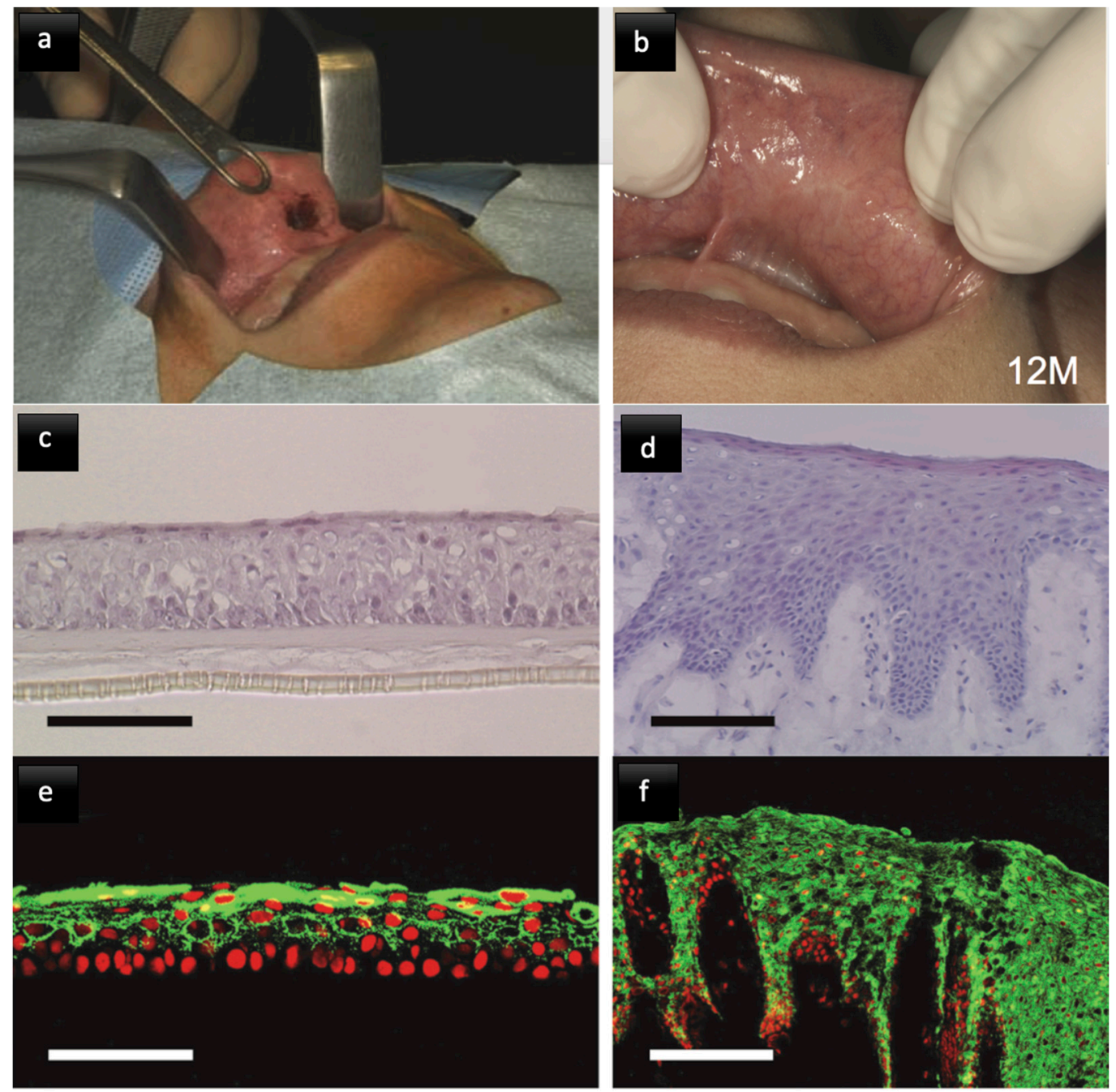

Figure 6. $(\mathbf{a}, \mathbf{b})$ Auto transplantation procedure for an oral mucosal defect for pleomorphic adenoma at the time of surgery and 12 months after surgery, respectively; (c-f) morphology and keratin expression patterns of amniotic membrane-cultured oral mucosal cells and oral mucosa; haematoxylin and eosin stained mucosal epithelial cells exhibiting seven differentiated and stratified layers (c) as compared to oral mucosa in vivo (d); keratins (green) expressed in the cultured mucosal cells (e) vs. oral mucosa (f); and nuclei stained with propidium iodide (red). Scale bars: (c,e) $100 \mu \mathrm{m}$ and (d,f) $200 \mu \mathrm{m}$. Images derived from Amemiya et al. [236].

(B) Natural polymers and scaffolds

Human-derived Acellular Dermal Matrices (ADM) are one of the more common scaffold materials which mimic ECM to provide a favourable environment for cell growth and growth factor exchange [238]. Similar scaffolds can be generated of xenogeneic origin like porcine graft, which showed positive outcomes as a scaffold [239]. Collagen and chitin fibres are a few of the other natural polymers which can be used in various forms, microscopic to nanometric, to form scaffolds for cell proliferation [240]. A comprehensive review of synthetic and natural graft materials has been provided by Toledano et al. [241].

(C) Synthetic polymers

The most common synthetic polymers used as mentioned above as well are poly( $\varepsilon$-caprolactone) (PCL), poly (glycolic acid) (PGA), poly (lactic acid) (PLA), poly (hydroxyl butyric acid), and poly (hydroxyl valeric acid), all of which are resorbable. They offer more significant advantages over natural ones, as they have longer shelf life, can be manufactured in bulk, and have better control over physical 
and chemical properties. However, their stiffness and fragility were seen to increase because they have been recently used mixed with non-resorbable polymers, (MMA) $)_{1}$-co-(HEMA $)_{1}$ and $(\mathrm{MA})_{3}$-co-(HEA) $)_{2}$. As the synthetic grafts have limited biological interactions, they have to be impregnated with bioactive molecules, which can be growth factors directly (BMPs and VEGF) or other molecules with stimulatory effects like $\mathrm{Si}$ and zinc oxide [242]. Electrospun nanofibres, as mentioned before, offer greater surface area and favourable porosity in addition to the capacity to carry growth factors as well as drugs such as antibiotics. They can be used as a dressing in relieving patient discomfort in patients with oral mucosal defects [243]. The upcoming strategies for mucosal regeneration have outstanding clinical outcomes, are economically sound, and can be harvested in greater quantities, thus providing reliable alternatives to conventional autografts.

\section{Biomimetics of Periodontal Tissue Engineering and Regeneration}

Periodontium is another highly specialised tissue in the oral and maxillofacial region. Common aetiologies for its loss are periodontitis and loss of tooth due to trauma or caries. Periodontitis is an inflammatory disease that leads to destruction of the tooth attachment apparatus, consisting of the gingival tissue, alveolar bone, cementum, and periodontal ligament (PDL). It is also associated with several systemic diseases such as cardiovascular diseases and rheumatoid arthritis. It is one of the most widespread infectious diseases and is the leading cause of tooth loss in adults [244]. Periodontal treatment aims to arrest further progression of the disease and to restore tissue integrity. Scaling and root planing are nonsurgical mechanical approaches to control disease progression [245]. Once tissue destruction has occurred, regenerative treatments are needed. Here, we have highlighted the key strategies in periodontal tissue regeneration, with a brief view on biomimetic strategies for oral implantology.

\subsection{Periodontal Regeneration}

\subsubsection{Cell-Based Therapies}

Currently, there are several surgical techniques used for periodontal regenerative therapy, including guided tissue regeneration (GTR), bone graft placement, as well as a variety of different biomaterials and growth factors [246]. Each technique has its advantages, yet the ability to completely regenerate the damaged periodontal structures has not been achieved in patients, especially in those with advanced periodontal defects [247]. In recent years, progress in stem cell biology and tissue engineering has ushered in stem cell-based approaches in regenerative therapies. Many studies have shown that stem cells can be used in conjunction with different physical matrices to regenerate periodontal tissues in vivo [248-250]. Stem cells used for periodontal therapy are usually mesenchymal stem cells (MSCs), since these cells are capable of differentiating into many tissues (bone, ligament, muscle, etc.) [251]. Also, they have an immunosuppressive capacity that gives them essential features in autologous and allogenic transplantation [252]. MSCs can be isolated from a variety of sources. Studies using animal models have shown successful periodontal tissue regeneration with MSCs derived from bone marrow [253], adipose tissue [254], and PDL [255]. While there is no consensus on which tissue source provides the most appropriate stem cells, researchers have focused on stem cells obtained from the oral cavity due to their accessibility as well as their high differentiation and proliferation abilities [256]. Oral stem cells have neural crest origin and thus represent a transient population of embryonic pluripotent stem cells [257]. Induced pluripotent stem (iPS) cells and embryonic stem cells have also been proposed for periodontal regeneration [258]. However, there seem to be limitations to this and it has not been carried out in practice [259]. There is evidence that the cells of PDL tissues are able to form a complete periodontal attachment apparatus [248]. One study examined the immunomodulatory properties of PDL stem cells, a type of MSC, and found that PDL stem cells inhibited the proliferation of activated peripheral blood mononuclear cells (PMBCs) via a partly dependent mechanism through interferon- $\gamma$, which is synthesized by activated PMBCs $[258,260]$. The disadvantage of PDL stem cells 
is that the cell regenerative potential seems to decrease as a function of the age of the donor [261]. Traditionally, PDL cells were collected from extracted teeth, which presented an issue because of the limited amount of PDL tissue on extracted teeth [255]. This is because stem cells are required in large quantities to accomplish clinical trials [254]. However, recent studies have shown that PDL stem cells can be procured from inflamed tissue within a periodontal defect [262]. This provides an easy and rapid alternative method to obtain PDL stem cells without extracting teeth.

Cells implanted into periodontal defects in immunocompromised rodents can regenerate cementum and PDL-like structures and can support periodontal tissue repair [263]. Other similar studies have demonstrated cementum, new bone, and PDL formation in larger animals like dogs [264] and pigs [265]. One study evaluated the regeneration of peri-implantitis defects in dogs using genetically modified PDL stem cells. Bone morphogenetic proteins (BMPs) have great potential in the regeneration of periodontal tissues [266]. Following the ex vivo transfer of the BMP-2 gene into PDL stem cells using an adenoviral vector, modified stem cells were implanted into the defects. This resulted in enhanced new bone formation and re-osseointegration in peri-implantitis defects compared with direct BMP administration to periodontal lesions [267]. Another finding that demonstrates the PDL cells' ability for bone regeneration and maintenance is that they release important humoral factors to maintain alveolar bone. When PDL stem cells are cultured in an indirect co-culture model, they inhibit osteoclastic activity of alveolar bone-derived stromal cells, therefore preserving alveolar bone [268]. Biomaterials used in combination with stem cells have the potential to improve the beneficial effects shown by cell therapy and lead to better control of cell delivery to the target site and to decrease the number of cells lost. They also play an essential role in the delivery of biological agents that enhance interaction with the host tissue and improve the cell differentiation process [269]. Because there are several different biomaterials available (natural biomaterials, ceramic biomaterials, and synthetic polymers), many animal studies have been conducted using different combinations of biomaterials and PDL stem cells for periodontal regeneration [270]. In one study, Tsunmanuma et al. showed that canine PDL cell sheets combined with a mixture of collagen and beta-tricalcium phosphate lead to improved cementum and PDL fibre formation in a canine 1-wall defect model [271]. Biological agents also have an effect on PDL cells in periodontal regenerating. For example, insulin-like growth factor-1 (IGF-1) has been shown to increase osteogenic differentiation and produces a cascade of downstream reactions, playing a pivotal role in cell-based periodontal tissue regeneration [272].

Over the past few years, stem cell-based periodontal therapies have begun testing in clinical settings $[273,274]$. In a 2016 RCT study by Chen et al., autologous PDL stem cells from extracted wisdom teeth were used as an adjuvant to graft materials (bovine-derived bone mineral materials) in GTR therapy to treat periodontal intrabony defects. While there was a significant decrease in bone defect, no statistically significant differences were detected between the PDL stem cell group and the control group [275]. However, the study demonstrated that it is safe to use PDL stem cells in treating periodontal intrabony defects in humans. Stem cell-based regenerative periodontal therapy is a promising new field that has the potential to prevent tooth loss, to avoid costly treatments, and to provide more effective and less invasive treatment options. While there remain many issues that need to be addressed before stem cell therapy becomes widely available, clinicians should continue to monitor these technologies' progression.

\subsubsection{Cell-Free Therapies}

Alveolar ridge deficiencies can complicate implant placement as well as other prosthodontic reconstruction. Therefore, to gain adequate alveolar ridge dimensions, many bone regeneration techniques have been used with conjunctive therapy to optimize bone growth. Specifically, Growth Factors (GFs) and Platelet-Rich Fibrin (PRF) techniques have been shown to aid in bone healing following graft placements. GFs are expressed during tissue healing and can promote tissue regeneration when used in surgical procedures [276]. PRF allows us to obtain GFs directly from the plasma and is therefore widely used to aid tissue regeneration. It has a positive effect on cell proliferation, migration, adhesion, 
and differentiation. Additionally, Strauss et al. have shown the anti-inflammatory properties of PRF [277], which support their role in wound healing and bone regeneration. According to a systematic review by Strauss et al., PRF does have a clinical benefit on ridge preservation and in the early phase of osseointegration. However, pain and soft tissue healing outcomes remain unclear [277]. Another systematic review by Dragonas et al. reported some benefit on soft tissue healing and post-op and swelling [278]. PRF used in conjugation with other bone grafts has shown better clinical outcomes than when used alone [279-282]. In patients with chronic periodontitis, the use of $1 \%$ metformin and PRF showed more pocket depth reduction and relative attachment level than either group alone [283]. Along with open-flap debridement, PRF has been shown to increase canine periodontitis treatment outcomes in animal studies [284].

Furthermore, growth factors alone or derived from cells have also given promising results, given the fact that endocrinal secretions of the cells are responsible for the regenerative effects in tissues [285]. A sequential application of basic fibroblast growth factors and BMP-2 synergistically promoted differentiation of periodontal ligament cells, suggesting their potential use for periodontal regeneration [286]. A meta-analysis, however, suggested that recombinant human BMP2 and PDGF-BB, in its current concentrations, did not induce a significant effect on tooth extraction socket healing, sinus augmentation, or reconstruction of alveolar defects. However, $0.3 \mathrm{mg} / \mathrm{mL}$ rhPDGF-BB may promote the healing of sockets [228]. Another meta-analysis showed that $0.3 \% \mathrm{rhFGF} 2$ and $0.3 \mathrm{mg} / \mathrm{mL}$ rhPDGF-BB showed more periodontal regeneration capacity than other concentrations and control groups [287]. It was also shown that rhBMP-2 substantially increased bone levels in localised alveolar ridge augmentation procedures [288].

Apart from the growth factors, other proteins like amelogenin have an eminent role in periodontal regeneration, in addition to the enamel formation discussed above [289]. Specifically, Emdogain, a porcine-derived extract of enamel matrix with proteins like amelogenin has gained attention due to its proliferative effect on cementoblasts [290], osteoblasts [291], endothelial cells [291], gingival fibroblasts [291,292], and periodontal stem cells [293]; to gingival and periodontal fibre growth and attachment; and to an anti-inflammatory effect. A systematic review conducted by Esposito et al. found that adjunctive use of Emdogain regenerates around $1 \mathrm{~mm}$ more tissue than techniques like GTR alone. Moreover, Emdogain is simpler to use and has less complications [294]. No firm conclusion was drawn in other preclinical [295] and clinical systematic reviews, which can be attributed to the disparate nature of the studies [296].

Although PRF has been shown to have good tissue healing properties as it can be used like a guided tissue regeneration membrane, one of its main disadvantages is that it resorbs within seven days [297]. Comparatively, other membranes for periodontal regeneration typically require 4-6 weeks [298]. Overall, PRF and GFs have been shown to have significant clinical therapeutic outcomes when used in bone tissue regeneration. However, more research is necessary to assess their full clinical benefits and indications [297].

\subsubsection{Guided Tissue Regeneration}

Guided Tissue Regeneration (GTR) is one of several procedures that has been developed to treat periodontitis. The biological principle of this procedure is on the basis that a membrane barrier can prevent undesirable types of tissue cells from migrating into a wound while simultaneously allowing desired cell types to repopulate the wound, therefore allowing the regeneration of the desired type of tissue [299]. GTR membranes are surgically implanted, and there are currently two types of materials used in these barriers in clinical research applications which are non-resorbable and resorbable materials [270]. Compared to non-resorbable ones, resorbable barriers are often favoured as they eliminate the necessity for a second surgical procedure to remove the barrier [300]. Non-resorbable materials used in GTRs include polytetrafluoroethylene (PTFE) or titanium [270], while resorbable materials are made of synthetic or natural polymers with different combinations of biomaterials that allow the development of membranes with various structural, chemical, 
and mechanical properties [270]. Common resorbable membranes on the market are based on either polyesters or tissue-derived collagen, which both have limitations including unpredictable degradation and weak mechanical properties [270,300]. The GTR membranes need to have the following characteristics: (1) biocompatibility to prevent inflammatory responses when interacting with host tissues, (2) a proper degradation profile that matches new tissue formation, (3) proper physical and mechanical characteristics for in vivo placement, and (4) enough sustained strength to adequately perform barrier function and circumvent membrane collapse. Considering these requirements, several research groups have been working to design membranes with predictable rates of degradation, structures to maintain mechanical properties and bioactive properties, such as calcium-phosphate based growth factors for bone formation [300]. Over the past decades, many different biomaterials and their combinations have been made and tested with various levels of success to regenerate destroyed periodontal tissues treated by GTR [301]. To illustrate, a research was aimed to engineer and regenerate human long bone tissue by creating scaffolds from nanoparticles to mimic the natural histological structure of human long bone. They focused on polymer nanoparticle compositions due to its superior mechanical properties, high durability, and surface bioactivity. The group concluded that they successfully produced degradable, bioactive, and permeable composite hollow fibre membranes with a wet phase phase-inversion approach for guided and biomimetic bone tissue engineering [302]. In another attempt to form membrane barrier designs for GTR that mimic naturally occurring biological processes, a study conducted by Zhang et al. used natural eggshell membrane, a semipermeable membrane with two unique layers [301]. The results from this study showed that the soluble eggshell protein with poly lactic-co acid nanofibre (SEP/PLGA) electrospun membrane they made formed an interconnected porous network with strong mechanical properties. Moreover, biological study results suggested that SEP/PLGA nanofibres have the potential to improve cell attachment, proliferation, and spreading. Therefore, the study showed the promising potential of SEP/PLGA nanofibres for future GTR membrane application [303]. Due to the limitations of current common barrier membranes used for GTR, many researchers have focused on developing improved barrier membranes, often with designs that mimic biological processes. Although recent studies have shown promising potential in the field of GTR, further advancements and research are required before they can be used to help patients [270].

\subsection{Implant BIOMIMETICS}

\subsubsection{Surface Modification and Alternative Materials for Implant Osseointegration}

The most frequently used material in dental implantology is titanium; however, other materials such as zirconia have recently been introduced to the market [304]. Titanium is widely used due to its biocompatibility and mechanical properties, which allow for its osseointegration. An implant must be properly osseointegrated into the jaw to ensure long-term stability, resistance of biomechanical forces, and proper transfer of forces to the alveolar ridge, which in turn preserves bone [305]. Some of the drawbacks of titanium implants are its grey colour when placed in an aesthetic region in a patient with a thin biotype [306] and some rare yet reported titanium allergies [307]. The aesthetic disadvantage gave rise to the zirconium alternative, a bioinert non-resorbable metal oxide, which also shows comparable osseointegration [304]. A study comparing the peri-implant crevicular fluid (PICF) surrounding titanium and zirconium implants found no significant differences in the pro-inflammatory cytokine or bone metabolism mediators with the exception of leptin [308]. This finding correlates with the biocompatibility of both materials used in implantology. Zirconium implants are not as predictable as titanium implants. One study found degradation products of a zirconia-based implant only 29 months postoperatively [309]. Additional alternatives focusing on aesthetics include using a different system whereby the titanium implant's external colouring is pink, which reduces the potential of soft tissues appearing grey while maintaining the predictability of a titanium implant [306]. 
Another way to improve the osseointegration of implants is through surface modification of the titanium and zirconium. A study compared the osseointegration of zirconium implants with their surface modified through either blasting, etching, or both methods simultaneously [304]. All three modifications resulted in good biocompatibility and osseointegration when compared to the reference zirconium implant. They also had a better attachment to the gingival and bone tissue around the neck area compared to the reference implant [304]. In addition, surface modification using platelet-rich plasma has also been investigated. Platelet-rich plasma (PRP) is used to deliver osteogenic and angiogenic growth factors to speed up bone regeneration and tissue repair [310]. It stimulates the proliferation and differentiation of mesenchymal cells to osteoblasts to help with bone healing [310]. The PRP used in surgery is prepared from the patient's blood through centrifugation [311], and the implant's surface is later treated with the PRP. A randomized controlled study found that the PRP application onto the implants' surface enhanced stability and bone healing [312]. However, a recent systematic review investigating the use of PRP to aid in bone healing and implant success found that, while most studies had positive results, the predictability and effect that PRP application onto implants has on bone regeneration, osseointegration, and implant stability and success remains unclear [313].

\subsubsection{Antimicrobial/Anti-Inflammatory Aspects of Oral Implantology}

The oral cavity utilises a plaque biofilm to shield itself against microorganisms with its constant contact with various pathogenic microorganisms. However, plaque biofilm is one of the contributing factors to caries and other various dental diseases, such as periodontitis. To tackle this issue, various studies have been investigating antimicrobial agents as a solution [314,315]. Unfortunately, results are not promising due to the decreased efficiency of antibacterial agents as they are released and degraded quickly [314,315].

To increase antibacterial agents' efficiency, many studies have been investigating nanoparticles to ultimately minimize the development of dental diseases [314,316,317]. Nanoparticles carry unique physiochemical properties, including high charge density and large surface areas, which allow them to interact with the negatively charged surface of bacterial cells, preventing bacteria's cellular functions [314,316,317]. Thus, these properties allow the nanoparticles to maintain high levels of antimicrobial activity. The potential of nanoparticles can further be applied to the field of periodontology. The combination of dimethylaminohexadecyl methacrylate (DMAHDM), 2-methacryloyloxyethyl phosphorylcholine (MPC), and the nanoparticles of amorphous calcium phosphate (NACP) has been shown to be highly effective against pathogens associated with periodontitis [314,318-320]. In the presence of an in vitro subgingival biofilm, nanoparticles with $\mathrm{Ag}^{+}, \mathrm{Zn}^{2+}$, doxycycline, or synergistic with chlorhexidine ( $\mathrm{CHX}$ ) have also demonstrated the ability to prevent development of pathogenic microorganisms [314,318,319,321]. Furthermore, the nanoparticles with Ag present in toothpastes have been shown to diminish the presence of pathogens associated with periodontic diseases [314,322,323]. Glass and glass-ceramics are viewed as another means of enhancing antibacterial activities in the oral cavity [324]. Such structures are developed commonly by silica, composed of $\mathrm{Si}^{4+}, \mathrm{B}^{3+}$, and $\mathrm{P}^{3+}$, and by the glass's heat treatment [324-330]. In addition, these compositions play a crucial role in how practical their antibacterial activities are. With their unique ion-containing matrices, glass and glass-ceramics possess bioactive properties, including osteoinductive and osteoconductive abilities, allowing them to bond with bone tissues [324,331-334]. Glass and glass-ceramics have antibacterial activities as their surface matrices are integrated with ions, including $\mathrm{Ag}^{+}, \mathrm{Ce}^{3+}, \mathrm{Cu}^{+}, \mathrm{Sr}^{2+}$, and $\mathrm{Zn}^{2+}[324,331,335-338]$. The rate at which these ions are released is directly correlated to the glass or glass-ceramic surfaces' roughness level. The higher the surface roughness of the structure, the higher the rate at which the ions are released. Fernandes et al. noted that, among these ions, $\mathrm{Ag}^{+}$is the common ion that is doped on glass and glass-ceramics studied in recent studies [339]. Hence, these materials play a crucial role at the site of dental implants as Escherichia coli, Staphylococcus aureus, S. epidermidis, and Pseudomonas aeruginosa are identified to be present in 90\% of all dental implants [339-342]. It has been demonstrated that 45S5 Bioglass, which contains hydroxycarbonate apatite on its surface, can suppress S. sanguis, S. 
mutans, and Actinomyces viscosus [318,339]. A study by Fernandes et al. has shown that 45S5, which is a glass or glass-ceramics containing silicon, inhibits the development of E. coli, P. aeruginosa, S. epidermidis, Moraxella catarrhalis, and Enterococcus faecalis [339]. These examples of the glass structures indicate a means of delivering a significant antimicrobial activity in the oral cavity.

The use of titanium surface coating has been explored as a means to introduce antibacterial properties on implant settings as titanium is highly biocompatible and resistant against corrosion. Although titanium alloy alone is not effective to provide antibacterial properties, its combination with chitosan allows this co-polymer to prevent biofilm formation and bacterial growth on implant surfaces [343-345]. Chitosan is a linear polysaccharide that consists of $N$-acetyl-D-glucosamine and D-glucosamine units for which position 1 and 4 contain B links. Its unique structure provides chitosan with a range of properties, including its antibacterial ability, biodegradability, and cytocompatibility [345-352]. However, its variety of biological properties, especially its antibacterial properties, depends on the characteristic of chitosan, which includes origin, molar mass, the degree of acylation, and its condition at production. In addition, chitosan can be produced in various forms, such as nanoparticles, fibres, gels, membranes, and sponges, but each form has different effects on chitosan's biological properties [345,353-356]. A study by D'Almeida et al. (2017) found that a combination of titanium alloy and non-animal chitosan, which was developed using the coupling agent triethoxysilylpropyl succinic anhydride (TESPSA), was effective against the growth of E. coli and S. aureus $[345,357]$. This combination represents as an ideal coating due to the biocompatibility of titanium surface and the use of non-animal chitosan, which make the combination as non-allergic and tolerable for the oral cavity [345]. Overall, nanoparticles, glass-ceramics-based materials, and chitosan-coated titanium represent effective means to hinder the activity of pathogenic microorganisms where dental implants are placed. There are various combinations of these materials, and further research on these materials will help determine the most effective one in clinical settings.

\section{Conclusions}

In this review, we emphasized the current scenario of biomimetic analogues used in dentistry. It is evident that intensive research over the years has led to the development of highly innovative, futuristic biomaterials, and techniques to simulate and replace natural structures in the craniofacial region. Nevertheless, as a biomimetic consideration, naturally derived or biologically close materials are noted to have better clinical outcomes with higher chances for clinical translation and patient use. This can be attributed to the multifarious nature of biological systems, which are an interplay of physiological, physiochemical, mechanical, and metabolic processes occurring simultaneously. Thus, there is a need for an interdisciplinary approach integrating medicine, bioengineering, biotechnology, and computational sciences to advance the current research in dentofacial regeneration. A wide range of in vitro and animal model studies prove that novel treatments are in the pipeline towards ground-breaking clinical therapies. We conclude that dentistry has come a long way apropos of regenerative medicine; still, there are vast avenues to endeavour, seeking inspiration from other facets in biomedical research.

Author Contributions: Conceptualisation, S.D.T.; investigation, A.U. and S.P.; writing-original draft preparation, A.U., S.P., P.K., H.S., K.T.L., M.T., S.Z., and I.H.; writing-review and editing, A.U., S.P., and S.D.T.; supervision, S.D.T.; project administration, A.U., S.P., and S.D.T. All authors have read and agreed to the published version of the manuscript.

Funding: This research received no external funding.

Conflicts of Interest: The authors declare no conflict of interest.

\section{References}

1. Robinson, R. The organic constituent of enamel. Tufts Dent. Outlook 1945, 19, 5.

2. Featherstone, J.; Chaffee, B. The evidence for caries management by risk assessment $\left(C A M B R A{ }^{\circledR}\right)$. Adv. Dent. Res. 2018, 29, 9-14. [CrossRef] [PubMed] 
3. Pandya, M.; Diekwisch, T.G.H. Enamel biomimetics-fiction or future of dentistry. Int. J. Oral Sci. 2019, 11, 8. [CrossRef] [PubMed]

4. Chen, H.; Clarkson, B.H.; Sun, K.; Mansfield, J.F. Self-assembly of synthetic hydroxyapatite nanorods into an enamel prism-like structure. J. Colloid Interface Sci. 2005, 288, 97-103. [CrossRef]

5. Ren, F.; Ding, Y.; Ge, X.; Lu, X.; Wang, K.; Leng, Y. Growth of one-dimensional single-crystalline hydroxyapatite nanorods. J. Cryst. Growth 2012, 349, 75-82. [CrossRef]

6. Wang, H.; Xiao, Z.; Yang, J.; Lu, D.; Kishen, A.; Li, Y.; Chen, Z.; Que, K.; Zhang, Q.; Deng, X.; et al. Oriented and Ordered Biomimetic Remineralization of the Surface of Demineralized Dental Enamel Using HAP@ACP Nanoparticles Guided by Glycine. Sci. Rep. 2017, 7, 40701. [CrossRef]

7. Atsawasuwan, P.; Lu, X.; Ito, Y.; Chen, Y.; Gopinathan, G.; Evans, C.; Kulkarni, A.; Gibson, C.; Luan, X.; Diekwisch, T. Expression and function of enamel-related gene products in calvarial development. J. Dent. Res. 2013, 92, 622-628. [CrossRef]

8. Lijima, M.; Moriwaki, Y.; Wen, H.B.; Fincham, A.G.; Moradian-Oldak, J. Elongated Growth of Octacalcium Phosphate Crystals in Recombinant Amelogenin Gels under Controlled Ionic Flow. J. Dent. Res. 2002, 81, 69-73. [CrossRef]

9. Fan, D.; Iijima, M.; Bromley, K.M.; Yang, X.; Mathew, S.; Moradian-Oldak, J. The Cooperation of Enamelin and Amelogenin in Controlling Octacalcium Phosphate Crystal Morphology. Cells Tissues Organs 2011, 194, 194-198. [CrossRef]

10. Pandya, M.; Lin, T.; Li, L.; Allen, M.J.; Jin, T.; Luan, X.; Diekwisch, T.G.H. Posttranslational Amelogenin Processing and Changes in Matrix Assembly during Enamel Development. Front. Physiol. 2017, 8, 790. [CrossRef]

11. Li, Q.-L.; Ning, T.-Y.; Cao, Y.; Zhang, W.-b.; Mei, M.L.; Chu, C.H. A novel self-assembled oligopeptide amphiphile for biomimetic mineralization of enamel. BMC Biotechnol. 2014, 14, 32. [CrossRef] [PubMed]

12. Prajapati, S.; Ruan, Q.; Mukherjee, K.; Nutt, S.; Moradian-Oldak, J. The Presence of MMP-20 Reinforces Biomimetic Enamel Regrowth. J. Dent. Res. 2018, 97, 84-90. [CrossRef]

13. Shen, P.; Walker, G.D.; Yuan, Y.; Reynolds, C.; Stanton, D.P.; Fernando, J.R.; Reynolds, E.C. Importance of bioavailable calcium in fluoride dentifrices for enamel remineralization. J. Dent. 2018, 78, 59-64. [CrossRef] [PubMed]

14. Ma, X.; Lin, X.; Zhong, T.; Xie, F. Evaluation of the efficacy of casein phosphopeptide-amorphous calcium phosphate on remineralization of white spot lesions in vitro and clinical research: A systematic review and meta-analysis. BMC Oral Health 2019, 19, 1-11. [CrossRef] [PubMed]

15. Fernando, J.R.; Shen, P.; Sim, C.P.C.; Chen, Y.Y.; Walker, G.D.; Yuan, Y.; Reynolds, C.; Stanton, D.P.; MacRae, C.M.; Reynolds, E.C. Self-assembly of dental surface nanofilaments and remineralisation by SnF2 and CPP-ACP nanocomplexes. Sci. Rep. 2019, 9, 1285. [CrossRef] [PubMed]

16. Bossu, M.; Saccucci, M.; Salucci, A.; Di Giorgio, G.; Bruni, E.; Uccelletti, D.; Sarto, M.S.; Familiari, G.; Relucenti, M.; Polimeni, A. Enamel remineralization and repair results of Biomimetic Hydroxyapatite toothpaste on deciduous teeth: An effective option to fluoride toothpaste. J. Nanobiotechnol. 2019, 17, 17. [CrossRef]

17. Bakry, A.S.; Marghalani, H.Y.; Amin, O.A.; Tagami, J. The effect of a bioglass paste on enamel exposed to erosive challenge. J. Dent. 2014, 42, 1458-1463. [CrossRef]

18. Taha, A.A.; Patel, M.P.; Hill, R.G.; Fleming, P.S. The effect of bioactive glasses on enamel remineralization: A systematic review. J. Dent. 2017, 67, 9-17. [CrossRef]

19. Kohda, N.; Iijima, M.; Kawaguchi, K.; Toshima, H.; Muguruma, T.; Endo, K.; Mizoguchi, I. Inhibition of enamel demineralization and bond-strength properties of bioactive glass containing 4-META/MMA-TBB-based resin adhesive. Eur. J. Oral Sci. 2015, 123, 202-207. [CrossRef]

20. Manfred, L.; Covell, D.A.; Crowe, J.J.; Tufekci, E.; Mitchell, J.C. A novel biomimetic orthodontic bonding agent helps prevent white spot lesions adjacent to brackets. Angle Orthod. 2013, 83, 97-103. [CrossRef]

21. Liu, H.; Yan, X.; Pandya, M.; Luan, X.; Diekwisch, T.G.H. 4Daughters of the Enamel Organ: Development, Fate, and Function of the Stratum Intermedium, Stellate Reticulum, and Outer Enamel Epithelium. Stem Cells Dev. 2016, 25, 1580-1590. [CrossRef] [PubMed]

22. DenBesten, P.K.; Gao, C.; Li, W.; Mathews, C.H.E.; Gruenert, D.C. Development and characterization of an SV40 immortalized porcine ameloblast-like cell line. Eur. J. Oral Sci. 1999, 107, 276-281. [CrossRef] [PubMed] 
23. Arakaki, M.; Ishikawa, M.; Nakamura, T.; Iwamoto, T.; Yamada, A.; Fukumoto, E.; Saito, M.; Otsu, K.; Harada, H.; Yamada, Y. Role of epithelial-stem cell interactions during dental cell differentiation. J. Biol. Chem. 2012, 287, 10590-10601. [CrossRef]

24. Tjäderhane, L.; Carrilho, M.R.; Breschi, L.; Tay, F.R.; Pashley, D.H. Dentin basic structure and composition-An overview. Endod. Top. 2009, 20, 3-29. [CrossRef]

25. Fernando, D.; Attik, N.; Pradelle-Plasse, N.; Jackson, P.; Grosgogeat, B.; Colon, P. Bioactive glass for dentin remineralization: A systematic review. Mater. Sci. Eng. C Mater. Biol. Appl. 2017, 76, 1369-1377. [CrossRef]

26. Niu, L.-n.; Zhang, W.; Pashley, D.H.; Breschi, L.; Mao, J.; Chen, J.-H.; Tay, F.R. Biomimetic remineralization of dentin. Dent. Mater. 2014, 30, 77-96. [CrossRef] [PubMed]

27. Sauro, S.; Osorio, R.; Watson, T.F.; Toledano, M. Therapeutic effects of novel resin bonding systems containing bioactive glasses on mineral-depleted areas within the bonded-dentine interface. J. Mater. Sci. Mater. Med. 2012, 23, 1521-1532. [CrossRef]

28. Tezvergil-Mutluay, A.; Seseogullari-Dirihan, R.; Feitosa, V.P.; Cama, G.; Brauer, D.S.; Sauro, S. Effects of Composites Containing Bioactive Glasses on Demineralized Dentin. J. Dent. Res. 2017, 96, 999-1005. [CrossRef]

29. Jun, S.-K.; Yang, S.-A.; Kim, Y.-J.; El-Fiqi, A.; Mandakhbayar, N.; Kim, D.-S.; Roh, J.; Sauro, S.; Kim, H.-W.; Lee, J.-H.; et al. Multi-functional nano-adhesive releasing therapeutic ions for MMP-deactivation and remineralization. Sci. Rep. 2018, 8, 5663. [CrossRef]

30. Profeta, A.C.; Mannocci, F.; Foxton, R.; Watson, T.F.; Feitosa, V.P.; De Carlo, B.; Mongiorgi, R.; Valdré, G.; Sauro, S. Experimental etch-and-rinse adhesives doped with bioactive calcium silicate-based micro-fillers to generate therapeutic resin-dentin interfaces. Dent. Mater. 2013, 29, 729-741. [CrossRef]

31. Braga, R.R. Calcium phosphates as ion-releasing fillers in restorative resin-based materials. Dent. Mater. 2019, 35, 3-14. [CrossRef] [PubMed]

32. Osorio, R.; Cabello, I.; Toledano, M. Bioactivity of zinc-doped dental adhesives. J. Dent. 2014, 42, 403-412. [CrossRef] [PubMed]

33. Toledano, M.; Yamauti, M.; Ruiz-Requena, M.E.; Osorio, R. A ZnO-doped adhesive reduced collagen degradation favouring dentine remineralization. J. Dent. 2012, 40, 756-765. [CrossRef] [PubMed]

34. Gu, L.-S.; Kim, J.; Kim, Y.K.; Liu, Y.; Dickens, S.H.; Pashley, D.H.; Ling, J.-Q.; Tay, F.R. A chemical phosphorylation-inspired design for Type I collagen biomimetic remineralization. Dent. Mater. 2010, 26, 1077-1089. [CrossRef]

35. Tay, F.R.; Pashley, D.H. Guided tissue remineralisation of partially demineralised human dentine. Biomaterials 2008, 29, 1127-1137. [CrossRef] [PubMed]

36. Olszta, M.J.; Odom, D.J.; Douglas, E.P.; Gower, L.B. A New Paradigm for Biomineral Formation: Mineralization via an Amorphous Liquid-Phase Precursor. Connect. Tissue Res. 2003, 44, 326-334. [CrossRef]

37. Liu, Y.; Li, N.; Qi, Y.; Niu, L.-n.; Elshafiy, S.; Mao, J.; Breschi, L.; Pashley, D.H.; Tay, F.R. The use of sodium trimetaphosphate as a biomimetic analog of matrix phosphoproteins for remineralization of artificial caries-like dentin. Dent. Mater. 2011, 27, 465-477. [CrossRef]

38. Liu, Y.; Li, N.; Qi, Y.-p.; Dai, L.; Bryan, T.E.; Mao, J.; Pashley, D.H.; Tay, F.R. Intrafibrillar Collagen Mineralization Produced by Biomimetic Hierarchical Nanoapatite Assembly. Adv. Mater. 2011, 23, 975-980. [CrossRef]

39. Kim, Y.K.; Gu, L.-s.; Bryan, T.E.; Kim, J.R.; Chen, L.; Liu, Y.; Yoon, J.C.; Breschi, L.; Pashley, D.H.; Tay, F.R. Mineralisation of reconstituted collagen using polyvinylphosphonic acid/polyacrylic acid templating matrix protein analogues in the presence of calcium, phosphate and hydroxyl ions. Biomaterials 2010, 31, 6618-6627. [CrossRef]

40. Borén, D.L.; Jonasson, P.; Kvist, T. Long-term survival of endodontically treated teeth at a public dental specialist clinic. J. Endod. 2015, 41, 176-181. [CrossRef]

41. Fristad, I.; Molven, O.; Halse, A. Nonsurgically retreated root filled teeth-radiographic findings after 20-27 years. Int. Endod. J. 2004, 37, 12-18. [CrossRef] [PubMed]

42. Prati, C.; Pirani, C.; Zamparini, F.; Gatto, M.; Gandolfi, M. A 20-year historical prospective cohort study of root canal treatments. A Multilevel analysis. Int. Endod. J. 2018, 51, 955-968. [CrossRef] [PubMed]

43. Chen, L.; Shen, H.; Suh, B.I. Bioactive dental restorative materials: A review. Am. J. Dent. 2013, 26, 219. [PubMed] 
44. Hilton, T.J. Keys to Clinical Success with Pulp Capping: A Review of the Literature. Oper. Dent. 2009, 34, 615-625. [CrossRef] [PubMed]

45. Komabayashi, T.; Zhu, Q.; Eberhart, R.; Imai, Y. Current status of direct pulp-capping materials for permanent teeth. Dent. Mater. J. 2016, 35, 1-12. [CrossRef] [PubMed]

46. Ji, Y.-M.; Jeon, S.H.; Park, J.-Y.; Chung, J.-H.; Choung, Y.-H.; Choung, P.-H. Dental Stem Cell Therapy with Calcium Hydroxide in Dental Pulp Capping. Tissue Eng. Part A 2010, 16, 1823-1833. [CrossRef]

47. Sangwan, P.; Sangwan, A.; Duhan, J.; Rohilla, A. Tertiary dentinogenesis with calcium hydroxide: A review of proposed mechanisms. Int. Endod. J. 2013, 46, 3-19. [CrossRef]

48. Natale, L.C.; Rodrigues, M.C.; Xavier, T.A.; Simões, A.; de Souza, D.N.; Braga, R.R. Ion release and mechanical properties of calcium silicate and calcium hydroxide materials used for pulp capping. Int. Endod. J. 2015, 48, 89-94. [CrossRef]

49. Tawil, P.Z.; Duggan, D.J.; Galicia, J.C. Mineral trioxide aggregate (MTA): Its history, composition, and clinical applications. Compend. Contin. Educ. Dent. (Jamesburg NJ 1995) 2015, 36, 247-252; quiz 254, 264.

50. Ford, T.R.P.; Torabinejad, M.; Abedi, H.R.; Bakland, L.K.; Kariyawasam, S.P. Using mineral trioxide aggregate as a pulp-capping material. J. Am. Dent. Assoc. 1996, 127, 1491-1494. [CrossRef]

51. Nielsen, M.J.; Casey, J.A.; VanderWeele, R.A.; Vandewalle, K.S. Mechanical properties of new dental pulp-capping materials. Gen. Dent. 2016, 64, 44-48. [PubMed]

52. Norrby, K. Mast cells and angiogenesis. APMIS 2002, 110, 355-371. [CrossRef] [PubMed]

53. Oguntebi, B.; Clark, A.; Wilson, J. Pulp capping with Bioglass ${ }^{\circledR}$ and autologous demineralized dentin in miniature swine. J. Dent. Res. 1993, 72, 484-489. [CrossRef] [PubMed]

54. Mocquot, C.; Colon, P.; Fernando, D.; Jackson, P.; Pradelle-Plasse, N.; Grosgogeat, B.; Attik, N. The infuence of experimental bioactive glasses on pulp cells behavior in vitro. Dent. Mater. 2020, 36, 1322-1331. [CrossRef] [PubMed]

55. Luo, Z.; Kohli, M.R.; Yu, Q.; Kim, S.; Qu, T.; He, W.-X. Biodentine Induces Human Dental Pulp Stem Cell Differentiation through Mitogen-activated Protein Kinase and Calcium-/Calmodulin-dependent Protein Kinase II Pathways. J. Endod. 2014, 40, 937-942. [CrossRef] [PubMed]

56. Laurent, P.; Camps, J.; About, I. BiodentineTM induces TGF- $\beta 1$ release from human pulp cells and early dental pulp mineralization. Int. Endod. J. 2012, 45, 439-448. [CrossRef]

57. Asgary, S.; Nazarian, H.; Khojasteh, A.; Shokouhinejad, N. Gene Expression and Cytokine Release during Odontogenic Differentiation of Human Dental Pulp Stem Cells Induced by 2 Endodontic Biomaterials. J. Endod. 2014, 40, 387-392. [CrossRef]

58. Lutfi, A.; Kannan, T.; Fazliah, M.; Jamaruddin, M.; Saidi, J. Proliferative activity of cells from remaining dental pulp in response to treatment with dental materials. Aust. Dent. J. 2010, 55, 79-85. [CrossRef]

59. Dammaschke, T.; Stratmann, U.; Fischer, R.-J.; Sagheri, D.; Schäfer, E. Proliferation of rat molar pulp cells after direct pulp capping with dentine adhesive and calcium hydroxide. Clin. Oral Investig. 2011, 15, 577-587. [CrossRef]

60. Tran-Hung, L.; Laurent, P.; Camps, J.; About, I. Quantification of angiogenic growth factors released by human dental cells after injury. Arch. Oral Biol. 2008, 53, 9-13. [CrossRef]

61. Guven, E.P.; Yalvac, M.E.; Sahin, F.; Yazici, M.M.; Rizvanov, A.A.; Bayirli, G. Effect of Dental Materials Calcium Hydroxide-containing Cement, Mineral Trioxide Aggregate, and Enamel Matrix Derivative on Proliferation and Differentiation of Human Tooth Germ Stem Cells. J. Endod. 2011, 37, 650-656. [CrossRef] [PubMed]

62. Schlueter, S.R.; Carnes , D.L., Jr.; Cochran, D.L. In Vitro Effects of Enamel Matrix Derivative on Microvascular Cells. J. Periodontol. 2007, 78, 141-151. [CrossRef] [PubMed]

63. Olsson, H.; Davies, J.R.; Holst, K.E.; Schröder, U.; Petersson, K. Dental pulp capping: Effect of Emdogain Gel on experimentally exposed human pulps. Int. Endod. J. 2005, 38, 186-194. [CrossRef] [PubMed]

64. Morotomi, T.; Washio, A.; Kitamura, C. Current and future options for dental pulp therapy. Jpn. Dent. Sci. Rev. 2019, 55, 5-11. [CrossRef]

65. Sonoyama, W.; Liu, Y.; Fang, D.; Yamaza, T.; Seo, B.-M.; Zhang, C.; Liu, H.; Gronthos, S.; Wang, C.-Y.; Shi, S. Mesenchymal stem cell-mediated functional tooth regeneration in swine. PLoS ONE 2006, 1, e79. [CrossRef] [PubMed] 
66. Huang, G.-J.; Gronthos, S.; Shi, S. Critical reviews in oral biology \& medicine: Mesenchymal stem cells derived from dental tissues vs. those from other sources: Their biology and role in regenerative medicine. J. Dent. Res. 2009, 88, 792.

67. Sonoyama, W.; Liu, Y.; Yamaza, T.; Tuan, R.S.; Wang, S.; Shi, S.; Huang, G.T.-J. Characterization of the apical papilla and its residing stem cells from human immature permanent teeth: A pilot study. J. Endod. 2008, 34, 166-171. [CrossRef] [PubMed]

68. Abe, S.; Yamaguchi, S.; Amagasa, T. Multilineage cells from apical pulp of human tooth with immature apex. Oral Sci. Int. 2007, 4, 45-58. [CrossRef]

69. Koyama, N.; Okubo, Y.; Nakao, K.; Bessho, K. Evaluation of pluripotency in human dental pulp cells. J. Oral Maxillofac. Surg. 2009, 67, 501-506. [CrossRef]

70. d'Aquino, R.; Graziano, A.; Sampaolesi, M.; Laino, G.; Pirozzi, G.; De Rosa, A.; Papaccio, G. Human postnatal dental pulp cells co-differentiate into osteoblasts and endotheliocytes: A pivotal synergy leading to adult bone tissue formation. Cell Death Differ. 2007, 14, 1162-1171. [CrossRef]

71. Arthur, A.; Rychkov, G.; Shi, S.; Koblar, S.A.; Gronthos, S. Adult human dental pulp stem cells differentiate toward functionally active neurons under appropriate environmental cues. Stem Cells 2008, 26, 1787-1795. [CrossRef] [PubMed]

72. Gronthos, S.; Mankani, M.; Brahim, J.; Robey, P.G.; Shi, S. Postnatal human dental pulp stem cells (DPSCs) in vitro and in vivo. Proc. Natl. Acad. Sci. USA 2000, 97, 13625-13630. [CrossRef] [PubMed]

73. Miura, M.; Gronthos, S.; Zhao, M.; Lu, B.; Fisher, L.W.; Robey, P.G.; Shi, S. SHED: Stem cells from human exfoliated deciduous teeth. Proc. Natl. Acad. Sci. USA 2003, 100, 5807-5812. [CrossRef] [PubMed]

74. Gronthos, S.; Brahim, J.; Li, W.; Fisher, L.; Cherman, N.; Boyde, A.; DenBesten, P.; Robey, P.G.; Shi, S. Stem cell properties of human dental pulp stem cells. J. Dent. Res. 2002, 81, 531-535. [CrossRef] [PubMed]

75. Lindroos, B.; Mäenpää, K.; Ylikomi, T.; Oja, H.; Suuronen, R.; Miettinen, S. Characterisation of human dental stem cells and buccal mucosa fibroblasts. Biochem. Biophys. Res. Commun. 2008, 368, 329-335. [CrossRef] [PubMed]

76. Zhang, W.; Walboomers, X.F.; Shi, S.; Fan, M.; Jansen, J.A. Multilineage differentiation potential of stem cells derived from human dental pulp after cryopreservation. Tissue Eng. 2006, 12, 2813-2823. [CrossRef]

77. Zhang, W.; Walboomers, X.F.; Van Kuppevelt, T.H.; Daamen, W.F.; Van Damme, P.A.; Bian, Z.; Jansen, J.A. In vivo evaluation of human dental pulp stem cells differentiated towards multiple lineages. J. Tissue Eng. Regen. Med. 2008, 2, 117-125. [CrossRef]

78. Shi, S.; Bartold, P.; Miura, M.; Seo, B.; Robey, P.; Gronthos, S. The efficacy of mesenchymal stem cells to regenerate and repair dental structures. Orthod. Craniofacial Res. 2005, 8, 191-199. [CrossRef]

79. Sakai, V.; Zhang, Z.; Dong, Z.; Neiva, K.; Machado, M.; Shi, S.; Santos, C.; Nör, J. SHED differentiate into functional odontoblasts and endothelium. J. Dent. Res. 2010, 89, 791-796. [CrossRef]

80. Nakamura, S.; Yamada, Y.; Katagiri, W.; Sugito, T.; Ito, K.; Ueda, M. Stem cell proliferation pathways comparison between human exfoliated deciduous teeth and dental pulp stem cells by gene expression profile from promising dental pulp. J. Endod. 2009, 35, 1536-1542. [CrossRef]

81. Alipour, R.; Sadeghi, F.; Hashemi-Beni, B.; Zarkesh-Esfahani, S.H.; Heydari, F.; Mousavi, S.B.; Adib, M.; Narimani, M.; Esmaeili, N. Phenotypic characterizations and comparison of adult dental stem cells with adipose-derived stem cells. Int. J. Prev. Med. 2010, 1, 164. [PubMed]

82. Nourbakhsh, N.; Soleimani, M.; Taghipour, Z.; Karbalaie, K.; Mousavi, S.-B.; Talebi, A.; Nadali, F.; Tanhaei, S.; Kiyani, G.-A.; Nematollahi, M. Induced in vitro differentiation of neural-like cells from human exfoliated deciduous teeth-derived stem cells. Int. J. Dev. Biol. 2011, 55, 189-195. [CrossRef] [PubMed]

83. Handa, K.; Saito, M.; Tsunoda, A.; Yamauchi, M.; Hattori, S.; Sato, S.; Toyoda, M.; Teranaka, T.; Narayanan, A.S. Progenitor cells from dental follicle are able to form cementum matrix in vivo. Connect. Tissue Res. 2002, 43, 406-408. [CrossRef] [PubMed]

84. Kémoun, P.; Laurencin-Dalicieux, S.; Rue, J.; Farges, J.-C.; Gennero, I.; Conte-Auriol, F.; Briand-Mesange, F.; Gadelorge, M.; Arzate, H.; Narayanan, A.S. Human dental follicle cells acquire cementoblast features under stimulation by BMP-2/-7 and enamel matrix derivatives (EMD) in vitro. Cell Tissue Res. 2007, 329, $283-294$. [CrossRef]

85. Völlner, F.; Ernst, W.; Driemel, O.; Morsczeck, C. A two-step strategy for neuronal differentiation in vitro of human dental follicle cells. Differentiation 2009, 77, 433-441. [CrossRef] 
86. Yalvac, M.E.; Ramazanoglu, M.; Gumru, O.Z.; Sahin, F.; Palotás, A.; Rizvanov, A.A. Comparison and optimisation of transfection of human dental follicle cells, a novel source of stem cells, with different chemical methods and electro-poration. Neurochem. Res. 2009, 34, 1272-1277. [CrossRef]

87. Lin, N.H.; Gronthos, S.; Bartold, P. Stem cells and periodontal regeneration. Aust. Dent. J. 2008, 53, $108-121$. [CrossRef]

88. Trevino, E.G.; Patwardhan, A.N.; Henry, M.A.; Perry, G.; Dybdal-Hargreaves, N.; Hargreaves, K.M.; Diogenes, A. Effect of irrigants on the survival of human stem cells of the apical papilla in a platelet-rich plasma scaffold in human root tips. J. Endod. 2011, 37, 1109-1115. [CrossRef]

89. Jadhav, G.; Shah, N.; Logani, A. Revascularization with and without Platelet-rich Plasma in Nonvital, Immature, Anterior Teeth: A Pilot Clinical Study. J. Endod. 2012, 38, 1581-1587. [CrossRef]

90. Chrepa, V.; Pitcher, B.; Henry, M.A.; Diogenes, A. Survival of the Apical Papilla and Its Resident Stem Cells in a Case of Advanced Pulpal Necrosis and Apical Periodontitis. J. Endod. 2017, 43, 561-567. [CrossRef]

91. Dianat, O.; Mashhadi Abas, F.; Paymanpour, P.; Eghbal, M.J.; Haddadpour, S.; Bahrololumi, N. Endodontic repair in immature dogs' teeth with apical periodontitis: Blood clot vs. plasma rich in growth factors scaffold. Dent. Traumatol. 2017, 33, 84-90. [CrossRef] [PubMed]

92. Torabinejad, M.; Turman, M. Revitalization of tooth with necrotic pulp and open apex by using platelet-rich plasma: A case report. J. Endod. 2011, 37, 265-268. [CrossRef]

93. Athirasala, A.; Tahayeri, A.; Thrivikraman, G.; França, C.M.; Monteiro, N.; Tran, V.; Ferracane, J.; Bertassoni, L.E. A dentin-derived hydrogel bioink for 3D bioprinting of cell laden scaffolds for regenerative dentistry. Biofabrication 2018, 10, 024101. [CrossRef] [PubMed]

94. Lambricht, L.; De Berdt, P.; Vanacker, J.; Leprince, J.; Diogenes, A.; Goldansaz, H.; Bouzin, C.; Préat, V.; Dupont-Gillain, C.; Des Rieux, A. The type and composition of alginate and hyaluronic-based hydrogels influence the viability of stem cells of the apical papilla. Dent. Mater. 2014, 30, e349-e361. [CrossRef] [PubMed]

95. Ferroni, L.; Gardin, C.; Sivolella, S.; Brunello, G.; Berengo, M.; Piattelli, A.; Bressan, E.; Zavan, B. A hyaluronan-based scaffold for the in vitro construction of dental pulp-like tissue. Int. J. Mol. Sci. 2015, 16, 4666-4681. [CrossRef] [PubMed]

96. Pardue, E.L.; Ibrahim, S.; Ramamurthi, A. Role of hyaluronan in angiogenesis and its utility to angiogenic tissue engineering. Organogenesis 2008, 4, 203-214. [CrossRef] [PubMed]

97. Friedman, P.M.; Mafong, E.A.; Kauvar, A.N.; Geronemus, R.G. Safety data of injectable nonanimal stabilized hyaluronic acid gel for soft tissue augmentation. Dermatol. Surg. 2002, 28, 491-494. [PubMed]

98. Souto, G.D.; Farhane, Z.; Casey, A.; Efeoglu, E.; McIntyre, J.; Byrne, H.J. Evaluation of cytotoxicity profile and intracellular localisation of doxorubicin-loaded chitosan nanoparticles. Anal. Bioanal. Chem. 2016, 408, 5443-5455. [CrossRef] [PubMed]

99. Shrestha, S.; Diogenes, A.; Kishen, A. Temporal-controlled release of bovine serum albumin from chitosan nanoparticles: Effect on the regulation of alkaline phosphatase activity in stem cells from apical papilla. J. Endod. 2014, 40, 1349-1354. [CrossRef]

100. Shrestha, S.; Torneck, C.D.; Kishen, A. Dentin conditioning with bioactive molecule releasing nanoparticle system enhances adherence, viability, and differentiation of stem cells from apical papilla. J. Endod. 2016, 42, 717-723. [CrossRef]

101. Ishimatsu, H.; Kitamura, C.; Morotomi, T.; Tabata, Y.; Nishihara, T.; Chen, K.-K.; Terashita, M. Formation of dentinal bridge on surface of regenerated dental pulp in dentin defects by controlled release of fibroblast growth factor-2 from gelatin hydrogels. J. Endod. 2009, 35, 858-865. [CrossRef] [PubMed]

102. Hoque, M.E.; Nuge, T.; Yeow, T.K.; Nordin, N.; Prasad, R. Gelatin based scaffolds for tissue engineering-a review. Polym. Res. J. 2015, 9, 15-32.

103. Svensson, A.; Nicklasson, E.; Harrah, T.; Panilaitis, B.; Kaplan, D.; Brittberg, M.; Gatenholm, P. Bacterial cellulose as a potential scaffold for tissue engineering of cartilage. Biomaterials 2005, 26, 419-431. [CrossRef] [PubMed]

104. Helenius, G.; Bäckdahl, H.; Bodin, A.; Nannmark, U.; Gatenholm, P.; Risberg, B. In vivo biocompatibility of bacterial cellulose. J. Biomed. Mater. Res. Part A Off. J. Soc. Biomater. Jpn. Soc. Biomater. Aust. Soc. Biomater. Korean Soc. Biomater. 2006, 76, 431-438. [CrossRef]

105. Gong, T.; Heng, B.C.; Lo, E.C.M.; Zhang, C. Current advance and future prospects of tissue engineering approach to dentin/pulp regenerative therapy. Stem Cells Int. 2016, 2016, 9204574. [CrossRef] 
106. Chang, B.; Ahuja, N.; Ma, C.; Liu, X. Injectable scaffolds: Preparation and application in dental and craniofacial regeneration. Mater. Sci. Eng. R Rep. 2017, 111, 1-26. [CrossRef]

107. Nosrat, A.; Kolahdouzan, A.; Khatibi, A.H.; Verma, P.; Jamshidi, D.; Nevins, A.J.; Torabinejad, M. Clinical, radiographic, and histologic outcome of regenerative endodontic treatment in human teeth using a novel collagen-hydroxyapatite scaffold. J. Endod. 2019, 45, 136-143. [CrossRef]

108. Kim, T.G.; Wikesjö, U.M.; Cho, K.S.; Chai, J.K.; Pippig, S.D.; Siedler, M.; Kim, C.K. Periodontal wound healing/regeneration following implantation of recombinant human growth/differentiation factor-5 (rhGDF-5) in an absorbable collagen sponge carrier into one-wall intrabony defects in dogs: A dose-range study. J. Clin. Periodontol. 2009, 36, 589-597. [CrossRef]

109. Sumita, Y.; Honda, M.J.; Ohara, T.; Tsuchiya, S.; Sagara, H.; Kagami, H.; Ueda, M. Performance of collagen sponge as a 3-D scaffold for tooth-tissue engineering. Biomaterials 2006, 27, 3238-3248. [CrossRef]

110. Nune, M.; Kumaraswamy, P.; Maheswari Krishnan, U.; Sethuraman, S. Self-assembling peptide nanofibrous scaffolds for tissue engineering: Novel approaches and strategies for effective functional regeneration. Curr. Protein Pept. Sci. 2013, 14, 70-84. [CrossRef]

111. Aligholi, H.; Rezayat, S.M.; Azari, H.; Mehr, S.E.; Akbari, M.; Mousavi, S.M.M.; Attari, F.; Alipour, F.; Hassanzadeh, G.; Gorji, A. Preparing neural stem/progenitor cells in PuraMatrix hydrogel for transplantation after brain injury in rats: A comparative methodological study. Brain Res. 2016, 1642, 197-208. [CrossRef] [PubMed]

112. Dissanayaka, W.L.; Hargreaves, K.M.; Jin, L.; Samaranayake, L.P.; Zhang, C. The interplay of dental pulp stem cells and endothelial cells in an injectable peptide hydrogel on angiogenesis and pulp regeneration in vivo. Tissue Eng. Part A 2015, 21, 550-563. [CrossRef] [PubMed]

113. Cavalcanti, B.N.; Zeitlin, B.D.; Nör, J.E. A hydrogel scaffold that maintains viability and supports differentiation of dental pulp stem cells. Dent. Mater. 2013, 29, 97-102. [CrossRef] [PubMed]

114. Wang, W.; Dang, M.; Zhang, Z.; Hu, J.; Eyster, T.W.; Ni, L.; Ma, P.X. Dentin regeneration by stem cells of apical papilla on injectable nanofibrous microspheres and stimulated by controlled BMP-2 release. Acta Biomater. 2016, 36, 63-72. [CrossRef] [PubMed]

115. Ceccarelli, G.; Presta, R.; Benedetti, L.; Cusella De Angelis, M.G.; Lupi, S.M.; Rodriguez y Baena, R. Emerging perspectives in scaffold for tissue engineering in oral surgery. Stem Cells Int. 2017, 2017. [CrossRef] [PubMed]

116. Ulery, B.D.; Nair, L.S.; Laurencin, C.T. Biomedical applications of biodegradable polymers. J. Polym. Sci. Part B Polym. Phys. 2011, 49, 832-864. [CrossRef]

117. Shiehzadeh, V.; Aghmasheh, F.; Shiehzadeh, F.; Joulae, M.; Kosarieh, E.; Shiehzadeh, F. Healing of large periapical lesions following delivery of dental stem cells with an injectable scaffold: New method and three case reports. Indian J. Dent. Res. 2014, 25, 248. [CrossRef]

118. Pérez, R.A.; Won, J.-E.; Knowles, J.C.; Kim, H.-W. Naturally and synthetic smart composite biomaterials for tissue regeneration. Adv. Drug Deliv. Rev. 2013, 65, 471-496. [CrossRef]

119. Moussa, D.G.; Aparicio, C. Present and future of tissue engineering scaffolds for dentin-pulp complex regeneration. J. Tissue Eng. Regen. Med. 2019, 13, 58-75. [CrossRef]

120. Tabarsi, B.; Pourghasem, M.; Moghaddamnia, A.; Shokravi, M.; Ehsani, M.; Ahmadyar, M.; Asgary, S. Comparison of skin test reactivity of two endodontic biomaterials in rabbits. Pak. J. Biol. Sci. 2012, 15, 250-254.

121. Nosrat, A.; Seifi, A.; Asgary, S. Pulpotomy in caries-exposed immature permanent molars using calcium-enriched mixture cement or mineral trioxide aggregate: A randomized clinical trial. Int. J. Paediatr. Dent. 2013, 23, 56-63. [CrossRef] [PubMed]

122. Azimi, S.; Fazlyab, M.; Sadri, D.; Saghiri, M.A.; Khosravanifard, B.; Asgary, S. Comparison of pulp response to mineral trioxide aggregate and a bioceramic paste in partial pulpotomy of sound human premolars: A randomized controlled trial. Int. Endod. J. 2014, 47, 873-881. [CrossRef] [PubMed]

123. Paula, A.B.; Laranjo, M.; Marto, C.M.; Paulo, S.; Abrantes, A.M.; Casalta-Lopes, J.; Marques-Ferreira, M.; Botelho, M.F.; Carrilho, E. Direct Pulp Capping: What is the Most Effective Therapy?-Systematic Review and Meta-Analysis. J. Evid. Dent. Pract. 2018, 18, 298-314. [CrossRef] [PubMed]

124. da Rosa, W.L.O.; Cocco, A.R.; Silva, T.M.D.; Mesquita, L.C.; Galarca, A.D.; Silva, A.F.D.; Piva, E. Current trends and future perspectives of dental pulp capping materials: A systematic review. J. Biomed. Mater. Res. Part B Appl. Biomater. 2018, 106, 1358-1368. [CrossRef] 
125. Celik, B.N.; Mutluay, M.S.; Arikan, V.; Sari, S. The evaluation of MTA and Biodentine as a pulpotomy materials for carious exposures in primary teeth. Clin. Oral Investig. 2019, 23, 661-666. [CrossRef]

126. Burger, E.H.; Klein-Nulend, J.; Van Der Plas, A.; Nijweide, P.J. Function of osteocytes in bone-Their role in mechanotransduction. J. Nutr. 1995, 125 (Suppl. 7), 2020S-2023S. [CrossRef]

127. Thi, M.M.; Suadicani, S.O.; Schaffler, M.B.; Weinbaum, S.; Spray, D.C. Mechanosensory responses of osteocytes to physiological forces occur along processes and not cell body and require $\alpha \mathrm{V} \beta 3$ integrin. Proc. Natl. Acad. Sci. USA 2013, 110, 21012-21017. [CrossRef]

128. Lloyd, S.A.; Loiselle, A.E.; Zhang, Y.; Donahue, H.J. Shifting paradigms on the role of connexin43 in the skeletal response to mechanical load. J. Bone Miner. Res. 2014, 29, 275-286. [CrossRef]

129. Cambra-Moo, O.; Nacarino Meneses, C.; Rodríguez Barbero, M.Á.; García Gil, O.; Rascón Pérez, J.; Rello-Varona, S.; D’Angelo, M.; Campo Martín, M.; González Martín, A. An approach to the histomorphological and histochemical variations of the humerus cortical bone through human ontogeny. J. Anat. 2014, 224, 634-646. [CrossRef]

130. Katsamenis, O.L.; Chong, H.M.; Andriotis, O.G.; Thurner, P.J. Load-bearing in cortical bone microstructure: Selective stiffening and heterogeneous strain distribution at the lamellar level. J. Mech. Behav. Biomed. Mater. 2013, 17, 152-165. [CrossRef]

131. Beddoe, A.; Darley, P.; Spiers, F. Measurements of trabecular bone structure in man (for radionuclide dosimetry. Phys. Med. Biol. 1976, 21, 589. [CrossRef] [PubMed]

132. Birmingham, E.; Grogan, J.; Niebur, G.; McNamara, L.; McHugh, P. Computational modelling of the mechanics of trabecular bone and marrow using fluid structure interaction techniques. Ann. Biomed. Eng. 2013, 41, 814-826. [CrossRef] [PubMed]

133. Nair, A.K.; Gautieri, A.; Chang, S.-W.; Buehler, M.J. Molecular mechanics of mineralized collagen fibrils in bone. Nat. Commun. 2013, 4, 1724. [CrossRef] [PubMed]

134. Itälä, A.; Koort, J.; Ylänen, H.O.; Hupa, M.; Aro, H.T. Biologic significance of surface microroughing in bone incorporation of porous bioactive glass implants. J. Biomed. Mater. Res. Part A 2003, 67A, 496-503. [CrossRef]

135. Launey, M.E.; Buehler, M.J.; Ritchie, R.O. On the Mechanistic Origins of Toughness in Bone. Annu. Rev. Mater. Res. 2010, 40, 25-53. [CrossRef]

136. Haugen, H.J.; Lyngstadaas, S.P.; Rossi, F.; Perale, G. Bone grafts: Which is the ideal biomaterial? J. Clin. Periodontol. 2019, 46 (Suppl. 21), 92-102. [CrossRef]

137. Misch, C.E.; Qu, Z.; Bidez, M.W. Mechanical properties of trabecular bone in the human mandible: Implications for dental implant treatment planning and surgical placement. J. Oral Maxillofac. Surg. 1999, 57, 700-706. [CrossRef]

138. Zhao, W.; Li, X.; Liu, X.; Zhang, N.; Wen, X. Effects of substrate stiffness on adipogenic and osteogenic differentiation of human mesenchymal stem cells. Mater. Sci. Eng. C 2014, 40, 316-323. [CrossRef]

139. Gittens, R.A.; Olivares-Navarrete, R.; Cheng, A.; Anderson, D.M.; McLachlan, T.; Stephan, I.; Geis-Gerstorfer, J.; Sandhage, K.H.; Fedorov, A.G.; Rupp, F.; et al. The roles of titanium surface micro/nanotopography and wettability on the differential response of human osteoblast lineage cells. Acta Biomater. 2013, 9, 6268-6277. [CrossRef]

140. Pamula, E.; Filová, E.; Bačáková, L.; Lisá, V.; Adamczyk, D. Resorbable polymeric scaffolds for bone tissue engineering: The influence of their microstructure on the growth of human osteoblast-like MG 63 cells. J. Biomed. Mater. Res. Part A 2009, 89A, 432-443. [CrossRef]

141. Ghayor, C.; Weber, F.E. Osteoconductive Microarchitecture of Bone Substitutes for Bone Regeneration Revisited. Front. Physiol. 2018, 9, 960. [CrossRef]

142. Murphy, C.M.; Haugh, M.G.; O’Brien, F.J. The effect of mean pore size on cell attachment, proliferation and migration in collagen-glycosaminoglycan scaffolds for bone tissue engineering. Biomaterials 2010, 31, 461-466. [CrossRef]

143. Sheikh, Z.; Abdallah, M.N.; Hanafi, A.A.; Misbahuddin, S.; Rashid, H.; Glogauer, M. Mechanisms of in Vivo Degradation and Resorption of Calcium Phosphate Based Biomaterials. Materials 2015, 8, 7913-7925. [CrossRef]

144. Thomas, M.V.; Puleo, D.A. Infection, inflammation, and bone regeneration: A paradoxical relationship. J. Dent. Res. 2011, 90, 1052-1061. [CrossRef] [PubMed]

145. Nuss, K.M.; von Rechenberg, B. Biocompatibility issues with modern implants in bone-a review for clinical orthopedics. Open Orthop. J. 2008, 2, 66. [CrossRef] [PubMed] 
146. Gristina, A. Biomaterial-centered infection: Microbial adhesion versus tissue integration. Science 1987, 237, 1588-1595. [CrossRef] [PubMed]

147. Giannoudis, P.V.; Chris Arts, J.J.; Schmidmaier, G.; Larsson, S. What should be the characteristics of the ideal bone graft substitute? Injury 2011, 42 (Suppl. 2), S1-S2. [CrossRef]

148. Juodzbalys, G. Regenerative bone potential after sinus floor elevation using various bone graft materials: A systematic review. Quintessence Int. 2019, 50, 548-558.

149. Jo, S.H.; Kim, Y.K.; Choi, Y.H. Histological Evaluation of the Healing Process of Various Bone Graft Materials after Engraftment into the Human Body. Materials 2018, 11, 714. [CrossRef]

150. Kunert-Keil, C.; Botzenhart, U.; Gedrange, T.; Gredes, T. Interrelationship between bone substitution materials and skeletal muscle tissue. Ann. Anat. 2015, 199, 73-78. [CrossRef]

151. Wang, X.; Shao, Z.; Zhang, H.Z.; Zhu, F.; Shen, H.; Shang, Z.J. Experimental study on ectopic prefabrication of vascularized mandible graft with autogenous ribs. Zhonghua Kou Qiang Yi Xue Za Zhi 2012, 47, 544-546. [PubMed]

152. Huang, R.-L.; Kobayashi, E.; Liu, K.; Li, Q. Bone Graft Prefabrication Following the In Vivo Bioreactor Principle. EBioMedicine 2016, 12, 43-54. [CrossRef] [PubMed]

153. Wang, W.; Yeung, K.W.K. Bone grafts and biomaterials substitutes for bone defect repair: A review. Bioact. Mater. 2017, 2, 224-247. [CrossRef]

154. Blume, O.; Donkiewicz, P.; Back, M.; Born, T. Bilateral maxillary augmentation using CAD/CAM manufactured allogenic bone blocks for restoration of congenitally missing teeth: A case report. J. Esthet. Restor. Dent. Off. Publ. Am. Acad. Esthet. Dent. 2019, 31, 171-178. [CrossRef]

155. Yamada, M.; Egusa, H. Current bone substitutes for implant dentistry. J Prosthodont Res 2018, 62, $152-161$. [CrossRef]

156. Peker, E.; Karaca, I.R.; Yildirim, B. Experimental Evaluation of the Effectiveness of Demineralized Bone Matrix and Collagenated Heterologous Bone Grafts Used Alone or in Combination with Platelet-Rich Fibrin on Bone Healing in Sinus Floor Augmentation. Int. J. Oral Maxillofac. Implant. 2016, 31, e24-e31. [CrossRef] [PubMed]

157. Lambert, F.; Lecloux, G.; Leonard, A.; Sourice, S.; Layrolle, P.; Rompen, E. Bone regeneration using porous titanium particles versus bovine hydroxyapatite: A sinus lift study in rabbits. Clin. Implant Dent. Relat. Res. 2013, 15, 412-426. [CrossRef] [PubMed]

158. Ng, J.; Spiller, K.; Bernhard, J.; Vunjak-Novakovic, G. Biomimetic approaches for bone tissue engineering. Tissue Eng. Part B Rev. 2017, 23, 480-493. [CrossRef]

159. Paduano, F.; Marrelli, M.; Alom, N.; Amer, M.; White, L.J.; Shakesheff, K.M.; Tatullo, M. Decellularized bone extracellular matrix and human dental pulp stem cells as a construct for bone regeneration. J. Biomater. Sci. Polym. Ed. 2017, 28, 730-748. [CrossRef] [PubMed]

160. Lin, X.; Patil, S.; Gao, Y.-G.; Qian, A. The Bone Extracellular Matrix in Bone Formation and Regeneration. Front. Pharmacol. 2020, 11, 757. [CrossRef]

161. Xu, X.; Chen, X.; Li, J. Natural protein bioinspired materials for regeneration of hard tissues. J. Mater. Chem. $B$ 2020, 8, 2199-2215. [CrossRef] [PubMed]

162. Dobretsov, S.; Abed, R.M.; Teplitski, M. Mini-review: Inhibition of biofouling by marine microorganisms. Biofouling 2013, 29, 423-441. [CrossRef] [PubMed]

163. Diaz-Rodriguez, P.; López-Álvarez, M.; Serra, J.; González, P.; Landín, M. Current stage of marine ceramic grafts for 3D bone tissue regeneration. Mar. Drugs 2019, 17, 471. [CrossRef] [PubMed]

164. Green, D.W.; Lai, W.F.; Jung, H.S. Evolving marine biomimetics for regenerative dentistry. Mar. Drugs 2014, 12, 2877-2912. [CrossRef] [PubMed]

165. Coringa, R.; de Sousa, E.M.; Botelho, J.N.; Diniz, R.S.; de Sá, J.C.; da Cruz, M.C.F.N.; Paschoal, M.A.B.; Gonçalves, L.M. Bone substitute made from a Brazilian oyster shell functions as a fast stimulator for bone-forming cells in an animal model. PLoS ONE 2018, 13, e0198697. [CrossRef] [PubMed]

166. Schubert, M.; Binnewerg, B.; Voronkina, A.; Muzychka, L.; Wysokowski, M.; Petrenko, I.; Kovalchuk, V.; Tsurkan, M.; Martinovic, R.; Bechmann, N.; et al. Naturally Prefabricated Marine Biomaterials: Isolation and Applications of Flat Chitinous 3D Scaffolds from Ianthella labyrinthus (Demospongiae: Verongiida). Int. J. Mol. Sci. 2019, 20, 5105. [CrossRef] 
167. Wong, S.H.M.; Lim, S.S.; Tiong, T.J.; Show, P.L.; Zaid, H.F.M.; Loh, H.S. Preliminary In Vitro Evaluation of Chitosan-Graphene Oxide Scaffolds on Osteoblastic Adhesion, Proliferation, and Early Differentiation. Int. J. Mol. Sci. 2020, 21, 5202. [CrossRef]

168. Moutinho, I.; da Costa Oliveira, I.; Santos, M.C.; Vasconcelos, M.; Portela, A. Different Chitosan-Based Biomaterials and their Biomedical Applications. Eur. J. Med. Res. Clin. Trials 2019, 1, 1-12.

169. LeGeros, R.Z. Properties of osteoconductive biomaterials: Calcium phosphates. A Publ. Assoc. Bone Jt. Surg. ${ }^{\circledR} \mid \operatorname{Corr}^{\circledR}$ 2002, 395, 81-98. [CrossRef]

170. Miron, R.J.; Sculean, A.; Shuang, Y.; Bosshardt, D.D.; Gruber, R.; Buser, D.; Chandad, F.; Zhang, Y. Osteoinductive potential of a novel biphasic calcium phosphate bone graft in comparison with autographs, xenografts, and DFDBA. Clin. Oral Implant. Res. 2016, 27, 668-675. [CrossRef]

171. Nevins, M.; Nevins, M.L.; Schupbach, P.; Kim, S.W.; Lin, Z.; Kim, D.M. A prospective, randomized controlled preclinical trial to evaluate different formulations of biphasic calcium phosphate in combination with a hydroxyapatite collagen membrane to reconstruct deficient alveolar ridges. J. Oral Implantol. 2013, 39, 133-139. [CrossRef] [PubMed]

172. Janssen, N.G.; de Ruiter, A.P.; van Hout, W.; van Miegem, V.; Gawlitta, D.; Groot, F.B.; Meijer, G.J.; Rosenberg, A.; Koole, R. Microstructured $\beta$-Tricalcium Phosphate Putty Versus Autologous Bone for Repair of Alveolar Clefts in a Goat Model. Cleft Palate Craniofac J. 2017, 54, 699-706. [CrossRef] [PubMed]

173. Marinucci, L.; Balloni, S.; Becchetti, E.; Bistoni, G.; Calvi, E.M.; Lumare, E.; Ederli, F.; Locci, P. Effects of Hydroxyapatite and Biostite ${ }^{\circledR}$ on Osteogenic Induction of hMSC. Ann. Biomed. Eng. 2010, 38, 640-648. [CrossRef] [PubMed]

174. Santarelli, A.; Mascitti, M.; Orsini, G.; Memè, L.; Rocchetti, R.; Tiriduzzi, P.; Sampalmieri, F.; Putignano, A.; Procaccini, M.; Lo Muzio, L.; et al. Osteopontin, osteocalcin and OB-cadherin expression in Synthetic nanohydroxyapatite vs. bovine hydroxyapatite cultured Osteoblastic-like cells. J. Biol. Regul. Homeost Agents 2014, 28, 523-529.

175. Dorozhkin, S.V. Calcium Orthophosphate-Based Bioceramics. Materials 2013, 6, 3840-3942. [CrossRef]

176. Jones, J.R. Review of bioactive glass: From Hench to hybrids. Acta Biomater. 2013, 9, 4457-4486. [CrossRef]

177. Hatton, J.; Davis, G.R.; Mourad, A.-H.I.; Cherupurakal, N.; Hill, R.G.; Mohsin, S. Fabrication of porous bone scaffolds using alginate and bioactive glass. J. Funct. Biomater. 2019, 10, 15. [CrossRef]

178. Migliaresi, C.; Motta, A. Scaffolds for Tissue Engineering: Biological Design, Materials, and Fabrication; CRC Press: Singapore, 2014.

179. Peroglio, M.; Gremillard, L.; Chevalier, J.; Chazeau, L.; Gauthier, C.; Hamaide, T. Toughening of bio-ceramics scaffolds by polymer coating. J. Eur. Ceram. Soc. 2007, 27, 2679-2685. [CrossRef]

180. Zhang, W.; Liao, S.; Cui, F. Hierarchical self-assembly of nano-fibrils in mineralized collagen. Chem. Mater. 2003, 15, 3221-3226. [CrossRef]

181. Feng, L.; Zhang, L.; Cui, Y.; Song, T.X.; Qiu, Z.Y.; Wang, X.M.; Tan, B.S. Clinical evaluations of mineralized collagen in the extraction sites preservation. Regen. Biomater. 2016, 3, 41-48. [CrossRef]

182. Rampichová, M.; Chvojka, J.; Jenčová, V.; Kubíková, T.; Tonar, Z.; Erben, J.; Buzgo, M.; Daňková, J.; Litvinec, A.; Vocetková, K.; et al. The combination of nanofibrous and microfibrous materials for enhancement of cell infiltration and in vivo bone tissue formation. Biomed. Mater. 2018, 13, 025004. [CrossRef] [PubMed]

183. McCullen, S.D.; Zhu, Y.; Bernacki, S.H.; Narayan, R.J.; Pourdeyhimi, B.; Gorga, R.E.; Loboa, E.G. Electrospun composite poly(L-lactic acid)/tricalcium phosphate scaffolds induce proliferation and osteogenic differentiation of human adipose-derived stem cells. Biomed. Mater. 2009, 4, 035002. [CrossRef] [PubMed]

184. Puwanun, S.; Delaine-Smith, R.M.; Colley, H.E.; Yates, J.M.; MacNeil, S.; Reilly, G.C. A simple rocker-induced mechanical stimulus upregulates mineralization by human osteoprogenitor cells in fibrous scaffolds. J. Tissue Eng. Regen. Med. 2018, 12, 370-381. [CrossRef] [PubMed]

185. Topsakal, A.; Uzun, M.; Ugar, G.; Ozcan, A.; Altun, E.; Oktar, F.N.; Ikram, F.; Ozkan, O.; Turkoglu Sasmazel, H.; Gunduz, O. Development of Amoxicillin-Loaded Electrospun Polyurethane/Chitosan/\$beta $\$$-Tricalcium Phosphate Scaffold for Bone Tissue Regeneration. IEEE Trans. Nanobioscience 2018, 17, 321-328. [CrossRef]

186. Zhang, C.Y.; Lu, H.; Zhuang, Z.; Wang, X.P.; Fang, Q.F. Nano-hydroxyapatite/poly(l-lactic acid) composite synthesized by a modified in situ precipitation: Preparation and properties. J. Mater. Sci. Mater. Med. 2010, 21, 3077-3083. [CrossRef] 
187. Chen, Z.; Song, Y.; Zhang, J.; Liu, W.; Cui, J.; Li, H.; Chen, F. Laminated electrospun nHA/PHB-composite scaffolds mimicking bone extracellular matrix for bone tissue engineering. Mater. Sci. Eng. C 2017, 72, 341-351. [CrossRef]

188. Zhou, P.; Yang, X.-L.; Wang, X.-G.; Hu, B.; Zhang, L.; Zhang, W.; Si, H.-R.; Zhu, Y.; Li, B.; Huang, C.-L.; et al. A pneumonia outbreak associated with a new coronavirus of probable bat origin. Nature 2020, 579, 270-273. [CrossRef]

189. Shi, R.; Gong, M.; Chi, C.; Huang, Y.; Li, W.; Li, G.; Ye, J.; Liao, M.; Zhang, L.; Tian, W. Nano twin-fiber membrane with osteogenic and antibacterial dual functions as artificial periosteum for long bone repairing. J. Biomed. Nanotechnol. 2019, 15, 272-287. [CrossRef]

190. Sharif, F.; Tabassum, S.; Mustafa, W.; Asif, A.; Zarif, F.; Tariq, M.; Siddiqui, S.A.; Gilani, M.A.; Ur Rehman, I.; MacNeil, S. Bioresorbable antibacterial PCL-PLA-nHA composite membranes for oral and maxillofacial defects. Polym. Compos. 2019, 40, 1564-1575. [CrossRef]

191. Corbella, S.; Taschieri, S.; Weinstein, R.; Del Fabbro, M. Histomorphometric outcomes after lateral sinus floor elevation procedure: A systematic review of the literature and meta-analysis. Clin. Oral Implant. Res. 2016, 27, 1106-1122. [CrossRef]

192. Starch-Jensen, T.; Mordenfeld, A.; Becktor, J.P.; Jensen, S.S. Maxillary Sinus Floor Augmentation With Synthetic Bone Substitutes Compared With Other Grafting Materials: A Systematic Review and Meta-analysis. Implant Dent. 2018, 27, 363-374. [CrossRef] [PubMed]

193. La Monaca, G.; Iezzi, G.; Cristalli, M.P.; Pranno, N.; Sfasciotti, G.L.; Vozza, I. Comparative Histological and Histomorphometric Results of Six Biomaterials Used in Two-Stage Maxillary Sinus Augmentation Model after 6-Month Healing. Biomed Res. Int. 2018, 2018, 9430989. [CrossRef] [PubMed]

194. Galindo-Moreno, P.; Padial-Molina, M.; Lopez-Chaichio, L.; Gutiérrez-Garrido, L.; Martín-Morales, N.; $\mathrm{O}^{\prime}$ Valle, F. Algae-derived hydroxyapatite behavior as bone biomaterial in comparison with anorganic bovine bone: A split-mouth clinical, radiological, and histologic randomized study in humans. Clin. Oral Implant. Res. 2020, 31, 536-548. [CrossRef] [PubMed]

195. Lee, J.S.; Shin, H.K.; Yun, J.H.; Cho, K.S. Randomized Clinical Trial of Maxillary Sinus Grafting using Deproteinized Porcine and Bovine Bone Mineral. Clin. Implant Dent. Relat. Res. 2017, 19, 140-150. [CrossRef] [PubMed]

196. Jelusic, D.; Zirk, M.L.; Fienitz, T.; Plancak, D.; Puhar, I.; Rothamel, D. Monophasic s-TCP vs. biphasic $\mathrm{HA} / \mathrm{s}-\mathrm{TCP}$ in two-stage sinus floor augmentation procedures-A prospective randomized clinical trial. Clin. Oral Implant. Res. 2017, 28, e175-e183. [CrossRef]

197. Pang, K.M.; Lee, J.K.; Choi, S.H.; Kim, Y.K.; Kim, B.J.; Lee, J.H. Maxillary Sinus Augmentation With Calcium Phosphate Double-Coated Anorganic Bovine Bone: Comparative Multicenter Randomized Clinical Trial With Histological and Radiographic Evaluation. Implant Dent. 2019, 28, 39-45. [CrossRef]

198. Stacchi, C.; Lombardi, T.; Oreglia, F.; Alberghini Maltoni, A.; Traini, T. Histologic and Histomorphometric Comparison between Sintered Nanohydroxyapatite and Anorganic Bovine Xenograft in Maxillary Sinus Grafting: A Split-Mouth Randomized Controlled Clinical Trial. Biomed Res. Int. 2017, 2017, 9489825. [CrossRef]

199. Palumbo, C.; Baldini, A.; Cavani, F.; Sena, P.; Benincasa, M.; Ferretti, M.; Zaffe, D. Immunocytochemical and structural comparative study of committed versus multipotent stem cells cultured with different biomaterials. Micron 2013, 47, 1-9. [CrossRef]

200. Hendrijantini, N.; Kusumaningsih, T.; Rostiny, R.; Mulawardhana, P.; Danudiningrat, C.P.; Rantam, F.A. A potential therapy of human umbilical cord mesenchymal stem cells for bone regeneration on osteoporotic mandibular bone. Eur. J. Dent. 2018, 12, 358-362. [CrossRef]

201. Gjerde, C.; Mustafa, K.; Hellem, S.; Rojewski, M.; Gjengedal, H.; Yassin, M.A.; Feng, X.; Skaale, S.; Berge, T.; Rosen, A. Cell therapy induced regeneration of severely atrophied mandibular bone in a clinical trial. Stem Cell Res. Ther. 2018, 9, 213. [CrossRef]

202. Peel Kim, H.; Ji, Y.-h.; Chul Rhee, S.; Sang Dhong, E.; Ha Park, S.; Yoon, E.-S. Enhancement of bone regeneration using osteogenic-induced adipose-derived stem cells combined with demineralized bone matrix in a rat critically-sized calvarial defect model. Curr. Stem Cell Res. Ther. 2012, 7, 165-172. [CrossRef] [PubMed] 
203. Chamieh, F.; Collignon, A.-M.; Coyac, B.R.; Lesieur, J.; Ribes, S.; Sadoine, J.; Llorens, A.; Nicoletti, A.; Letourneur, D.; Colombier, M.-L.; et al. Accelerated craniofacial bone regeneration through dense collagen gel scaffolds seeded with dental pulp stem cells. Sci. Rep. 2016, 6, 38814. [CrossRef] [PubMed]

204. D'Aquino, R.; De Rosa, A.; Lanza, V.; Tirino, V.; Laino, L.; Graziano, A.; Desiderio, V.; Laino, G.; Papaccio, G. Human mandible bone defect repair by the grafting of dental pulp stem/progenitor cells and collagen sponge biocomplexes. Eur. Cell Mater. 2009, 18, 75-83. [CrossRef] [PubMed]

205. Chamila Prageeth Pandula, P.; Samaranayake, L.; Jin, L.; Zhang, C. Periodontal ligament stem cells: An update and perspectives. J. Investig. Clin. Dent. 2014, 5, 81-90. [CrossRef] [PubMed]

206. Yamada, Y.; Ito, K.; Nakamura, S.; Ueda, M.; Nagasaka, T. Promising cell-based therapy for bone regeneration using stem cells from deciduous teeth, dental pulp, and bone marrow. Cell Transplant. 2011, 20, 1003-1013. [CrossRef] [PubMed]

207. Hiraki, T.; Kunimatsu, R.; Nakajima, K.; Abe, T.; Yamada, S.; Rikitake, K.; Tanimoto, K. Stem cell-derived conditioned media from human exfoliated deciduous teeth promote bone regeneration. Oral Dis. 2020, 26, 381-390. [CrossRef] [PubMed]

208. Katagiri, W.; Watanabe, J.; Toyama, N.; Osugi, M.; Sakaguchi, K.; Hibi, H. Clinical Study of Bone Regeneration by Conditioned Medium From Mesenchymal Stem Cells After Maxillary Sinus Floor Elevation. Implant Dent. 2017, 26, 607-612. [CrossRef]

209. Tsukamoto, J.; Naruse, K.; Nagai, Y.; Kan, S.; Nakamura, N.; Hata, M.; Omi, M.; Hayashi, T.; Kawai, T.; Matsubara, T. Efficacy of a self-assembling peptide hydrogel, SPG-178-gel, for bone regeneration and three-dimensional osteogenic induction of dental pulp stem cells. Tissue Eng. Part A 2017, 23, 1394-1402. [CrossRef]

210. Yu, B.-H.; Zhou, Q.; Wang, Z.-L. Periodontal ligament versus bone marrow mesenchymal stem cells in combination with Bio-Oss scaffolds for ectopic and in situ bone formation: A comparative study in the rat. J. Biomater. Appl. 2014, 29, 243-253. [CrossRef]

211. Korn, P.; Hauptstock, M.; Range, U.; Kunert-Keil, C.; Pradel, W.; Lauer, G.; Schulz, M.C. Application of tissue-engineered bone grafts for alveolar cleft osteoplasty in a rodent model. Clin. Oral Investig. 2017, 21, 2521-2534. [CrossRef]

212. Martin-del-Campo, M.; Rosales-Ibañez, R.; Alvarado, K.; Sampedro, J.G.; Garcia-Sepulveda, C.A.; Deb, S.; San Román, J.; Rojo, L. Strontium folate loaded biohybrid scaffolds seeded with dental pulp stem cells induce in vivo bone regeneration in critical sized defects. Biomater. Sci. 2016, 4, 1596-1604. [CrossRef] [PubMed]

213. Al-Ahmady, H.H.; Abd Elazeem, A.F.; Bellah Ahmed, N.E.-m.; Shawkat, W.M.; Elmasry, M.; Abdelrahman, M.A.; Abderazik, M.A. Combining autologous bone marrow mononuclear cells seeded on collagen sponge with Nano Hydroxyapatite, and platelet-rich fibrin: Reporting a novel strategy for alveolar cleft bone regeneration. J. Cranio-Maxillofac. Surg. 2018, 46, 1593-1600. [CrossRef] [PubMed]

214. Majidinia, M.; Sadeghpour, A.; Yousefi, B. The roles of signaling pathways in bone repair and regeneration. J. Cell. Physiol. 2018, 233, 2937-2948. [CrossRef] [PubMed]

215. Wang, F.; Li, Q.; Wang, Z. A comparative study of the effect of Bio-Oss ${ }^{\circledR}$ in combination with concentrated growth factors or bone marrow-derived mesenchymal stem cells in canine sinus grafting. J. Oral Pathol. Med. 2017, 46, 528-536. [CrossRef]

216. Fernandez-Yague, M.A.; Abbah, S.A.; McNamara, L.; Zeugolis, D.I.; Pandit, A.; Biggs, M.J. Biomimetic approaches in bone tissue engineering: Integrating biological and physicomechanical strategies. Adv. Drug Deliv. Rev. 2015, 84, 1-29. [CrossRef]

217. Wozney, J.M. The bone morphogenetic protein family and osteogenesis. Mol. Reprod. Dev. 1992, 32, $160-167$. [CrossRef]

218. Khojasteh, A.; Behnia, H.; Naghdi, N.; Esmaeelinejad, M.; Alikhassy, Z.; Stevens, M. Effects of different growth factors and carriers on bone regeneration: A systematic review. Oral Surg. Oral Med. Oral Pathol. Oral Radiol. 2013, 116, e405-e423. [CrossRef]

219. Sudheesh Kumar, P.T.; Hashimi, S.; Saifzadeh, S.; Ivanovski, S.; Vaquette, C. Additively manufactured biphasic construct loaded with BMP-2 for vertical bone regeneration: A pilot study in rabbit. Mater. Sci. Eng. C Mater Biol. Appl. 2018, 92, 554-564. [CrossRef]

220. Park, S.-Y.; Kim, K.-H.; Kim, S.; Lee, Y.-M.; Seol, Y.-J. BMP-2 gene delivery-based bone regeneration in dentistry. Pharmaceutics 2019, 11, 393. [CrossRef] 
221. Fliefel, R.; Kühnisch, J.; Ehrenfeld, M.; Otto, S. Gene Therapy for Bone Defects in Oral and Maxillofacial Surgery: A Systematic Review and Meta-Analysis of Animal Studies. Stem Cells Dev. 2016, 26, 215-230. [CrossRef]

222. Keramaris, N.; Calori, G.; Nikolaou, V.; Schemitsch, E.; Giannoudis, P. Fracture vascularity and bone healing: A systematic review of the role of VEGF. Injury 2008, 39, S45-S57. [CrossRef]

223. Patel, Z.S.; Young, S.; Tabata, Y.; Jansen, J.A.; Wong, M.E.; Mikos, A.G. Dual delivery of an angiogenic and an osteogenic growth factor for bone regeneration in a critical size defect model. Bone 2008, 43, 931-940. [CrossRef] [PubMed]

224. Kim, S.K.; Cho, T.H.; Han, J.J.; Kim, I.S.; Park, Y.; Hwang, S.J. Comparative study of BMP-2 alone and combined with VEGF carried by hydrogel for maxillary alveolar bone regeneration. Tissue Eng. Regen. Med. 2016, 13, 171-181. [CrossRef] [PubMed]

225. Beenken, A.; Mohammadi, M. The FGF family: Biology, pathophysiology and therapy. Nat. Rev. Drug Discov. 2009, 8, 235-253. [CrossRef]

226. Reible, B.; Schmidmaier, G.; Moghaddam, A.; Westhauser, F. Insulin-Like Growth Factor-1 as a Possible Alternative to Bone Morphogenetic Protein-7 to Induce Osteogenic Differentiation of Human Mesenchymal Stem Cells in Vitro. Int. J. Mol. Sci. 2018, 19, 1674. [CrossRef]

227. Caplan, A.I.; Correa, D. PDGF in bone formation and regeneration: New insights into a novel mechanism involving MSCs. J. Orthop. Res. 2011, 29, 1795-1803. [CrossRef]

228. Li, F.; Yu, F.; Liao, X.; Wu, C.; Wang, Y.; Li, C.; Lou, F.; Li, B.; Yin, B.; Wang, C.; et al. Efficacy of Recombinant Human BMP2 and PDGF-BB in Orofacial Bone Regeneration: A Systematic Review and Meta-analysis. Sci. Rep. 2019, 9, 8073. [CrossRef]

229. Hosseinpour, S.; Ghazizadeh Ahsaie, M.; Rezai Rad, M.; Baghani, M.t.; Motamedian, S.R.; Khojasteh, A. Application of selected scaffolds for bone tissue engineering: A systematic review. Oral Maxillofac. Surg. 2017, 21, 109-129. [CrossRef]

230. Stumbras, A.; Januzis, G.; Kubilius, R.; Gervickas, A.; Juodzbalys, G. Randomized clinical trial of bone healing after alveolar ridge preservation using xenografts and allografts vs. plasma rich in growth factors. J. Oral Implantol. 2020. [CrossRef]

231. Talaat, W.M.; Ghoneim, M.M.; Salah, O.; Adly, O.A. Autologous Bone Marrow Concentrates and Concentrated Growth Factors Accelerate Bone Regeneration After Enucleation of Mandibular Pathologic Lesions. J. Craniofacial Surg. 2018, 29, 992-997. [CrossRef]

232. Yu, T.-T.; Liu, J.; Yin, J.-J.; Xu, X.-N.; Yan, S.-J.; Lan, J. Effects of concentrated growth factors on relieving postoperative reaction of guided bone regeneration in the esthetic zone. Hua Xi Kou Qiang Yi Xue Za Zhi 2019, 37, 398-402. [PubMed]

233. Feinberg, S.E.; Aghaloo, T.L.; Cunningham, L.L. Role of tissue engineering in oral and maxillofacial reconstruction: Findings of the 2005 AAOMS Research Summit. J. Oral Maxillofac. Surg. 2005, 63, 1418-1425. [CrossRef] [PubMed]

234. Dhandayuthapani, B.; Yoshida, Y.; Maekawa, T.; Kumar, D.S. Polymeric scaffolds in tissue engineering application: A review. Int. J. Polym. Sci. 2011, 2011. [CrossRef]

235. Kato, H.; Marcelo, C.L.; Washington, J.B.; Bingham, E.L.; Feinberg, S.E. Fabrication of large size ex vivo-produced oral mucosal equivalents for clinical application. Tissue Eng. Part C Methods 2015, 21, 872-880. [CrossRef] [PubMed]

236. Amemiya, T.; Nakamura, T.; Yamamoto, T.; Kinoshita, S.; Kanamura, N. Autologous transplantation of oral mucosal epithelial cell sheets cultured on an amniotic membrane substrate for intraoral mucosal defects. PLoS ONE 2015, 10, e0125391. [CrossRef] [PubMed]

237. Köseoğlu, S.; Duran, İ.; Sağlam, M.; Bozkurt, S.B.; Kırtıloğlu, O.S.; Hakkı, S.S. Efficacy of collagen membrane seeded with autologous gingival fibroblasts in gingival recession treatment: A randomized, controlled pilot study. J. Periodontol. 2013, 84, 1416-1424. [CrossRef]

238. Fischer, K.R.; Testori, T.; Wachtel, H.; Mühlemann, S.; Happe, A.; Del Fabbro, M. Soft tissue augmentation applying a collagenated porcine dermal matrix during second stage surgery: A prospective multicenter case series. Clin. Implant Dent. Relat. Res. 2019, 21, 923-930. [CrossRef] [PubMed] 
239. De Santis, D.; Gelpi, F.; Castellani, R.; Palumbo, C.; Ferretti, M.; Zanotti, G.; Zotti, F.; Montagna, L.; Luciano, U.; Marconcini, S.; et al. Bi-layered collagen nano-structured membrane prototype collagen matrix CM-10826 for oral soft tissue regeneration: An in vivo ultrastructural study on 13 patients. J. Biol. Regul. Homeost Agents 2019, 33 (Suppl. 1), 29-41.

240. Echazú, M.I.A.; Tuttolomondo, M.V.; Foglia, M.L.; Mebert, A.M.; Alvarez, G.S.; Desimone, M.F. Advances in collagen, chitosan and silica biomaterials for oral tissue regeneration: From basics to clinical trials. J. Mater. Chem. B 2016, 4, 6913-6929. [CrossRef]

241. Toledano, M.; Toledano-Osorio, M.; Carrasco-Carmona, Á.; Vallecillo, C.; Lynch, C.D.; Osorio, M.T.; Osorio, R. State of the Art on Biomaterials for Soft Tissue Augmentation in the Oral Cavity. Part I: Natural Polymers-Based Biomaterials. Polymers 2020, 12, 1850. [CrossRef]

242. Toledano, M.; Toledano-Osorio, M.; Osorio, R.; Carrasco-Carmona, Á.; Gutiérrez-Pérez, J.-L.; Gutiérrez-Corrales, A.; Serrera-Figallo, M.-A.; Lynch, C.D.; Torres-Lagares, D. Doxycycline and Zinc Loaded Silica-Nanofibrous Polymers as Biomaterials for Bone Regeneration. Polymers 2020, 12, 1201. [CrossRef]

243. Blackwood, K.A.; McKean, R.; Canton, I.; Freeman, C.O.; Franklin, K.L.; Cole, D.; Brook, I.; Farthing, P.; Rimmer, S.; Haycock, J.W. Development of biodegradable electrospun scaffolds for dermal replacement. Biomaterials 2008, 29, 3091-3104. [CrossRef] [PubMed]

244. Pihlstrom, B.L.; Michalowicz, B.S.; Johnson, N.W. Periodontal diseases. Lancet 2005, 366, $1809-1820$. [CrossRef]

245. Tobita, M.; Mizuno, H. Periodontal disease and periodontal tissue regeneration. Curr. Stem Cell Res. 2010, 5 , 168-174. [CrossRef] [PubMed]

246. Villar, C.C.; Cochran, D.L. Regeneration of periodontal tissues: Guided tissue regeneration. Dent Clin. N. Am. 2010, 54, 73-92. [CrossRef] [PubMed]

247. Bosshardt, D.D.; Sculean, A. Does periodontal tissue regeneration really work? Periodontol 2000 2009, 51, 208-219. [CrossRef] [PubMed]

248. Caton, J.; Bostanci, N.; Remboutsika, E.; De Bari, C.; Mitsiadis, T.A. Future dentistry: Cell therapy meets tooth and periodontal repair and regeneration. J. Cell Mol. Med. 2011, 15, 1054-1065. [CrossRef]

249. Trubiani, O.; Orsini, G.; Zini, N.; Di Iorio, D.; Piccirilli, M.; Piattelli, A.; Caputi, S. Regenerative potential of human periodontal ligament derived stem cells on three-dimensional biomaterials: A morphological report. J. Biomed Mater Res. A 2008, 87, 986-993. [CrossRef]

250. Seo, B.M.; Miura, M.; Gronthos, S.; Bartold, P.M.; Batouli, S.; Brahim, J.; Young, M.; Robey, P.G.; Wang, C.Y.; Shi, S. Investigation of multipotent postnatal stem cells from human periodontal ligament. Lancet 2004, 364, 149-155. [CrossRef]

251. Chamberlain, G.; Fox, J.; Ashton, B.; Middleton, J. Concise review: Mesenchymal stem cells: Their phenotype, differentiation capacity, immunological features, and potential for homing. Stem Cells 2007, 25, 2739-2749. [CrossRef]

252. Qin, Y.; Guan, J.; Zhang, C. Mesenchymal stem cells: Mechanisms and role in bone regeneration. Postgrad Med. J. 2014, 90, 643-647. [CrossRef] [PubMed]

253. Hasegawa, N.; Kawaguchi, H.; Hirachi, A.; Takeda, K.; Mizuno, N.; Nishimura, M.; Koike, C.; Tsuji, K.; Iba, H.; Kato, Y.; et al. Behavior of transplanted bone marrow-derived mesenchymal stem cells in periodontal defects. J. Periodontol. 2006, 77, 1003-1007. [CrossRef] [PubMed]

254. Tobita, M.; Mizuno, H. Adipose-derived stem cells and periodontal tissue engineering. Int. J. Oral Maxillofac. Implant. 2013, 28, e487-e493. [CrossRef] [PubMed]

255. Benatti, B.B.; Silverio, K.G.; Casati, M.Z.; Sallum, E.A.; Nociti, F.H., Jr. Physiological features of periodontal regeneration and approaches for periodontal tissue engineering utilizing periodontal ligament cells. J. Biosci. Bioeng. 2007, 103, 1-6. [CrossRef]

256. Spagnuolo, G.; Codispoti, B.; Marrelli, M.; Rengo, C.; Rengo, S.; Tatullo, M. Commitment of Oral-Derived Stem Cells in Dental and Maxillofacial Applications. Dent. J. 2018, 6, 13. [CrossRef]

257. Trubiani, O.; Marconi, G.D.; Pierdomenico, S.D.; Piattelli, A.; Diomede, F.; Pizzicannella, J. Human Oral Stem Cells, Biomaterials and Extracellular Vesicles: A Promising Tool in Bone Tissue Repair. Int. J. Mol. Sci. 2019, 20, 9. [CrossRef] 
258. Duan, X.; Tu, Q.; Zhang, J.; Ye, J.; Sommer, C.; Mostoslavsky, G.; Kaplan, D.; Yang, P.; Chen, J. Application of induced pluripotent stem (iPS) cells in periodontal tissue regeneration. J. Cell Physiol. 2011, 226, 150-157. [CrossRef]

259. Csete, M. Translational prospects for human induced pluripotent stem cells. Regen. Med. 2010, 5, 509-519. [CrossRef]

260. Wada, N.; Menicanin, D.; Shi, S.; Bartold, P.M.; Gronthos, S. Immunomodulatory properties of human periodontal ligament stem cells. J. Cell Physiol. 2009, 219, 667-676. [CrossRef]

261. Zhang, J.; An, Y.; Gao, L.N.; Zhang, Y.J.; Jin, Y.; Chen, F.M. The effect of aging on the pluripotential capacity and regenerative potential of human periodontal ligament stem cells. Biomaterials 2012, 33, 6974-6986. [CrossRef]

262. Park, J.C.; Kim, J.M.; Jung, I.H.; Kim, J.C.; Choi, S.H.; Cho, K.S.; Kim, C.S. Isolation and characterization of human periodontal ligament (PDL) stem cells (PDLSCs) from the inflamed PDL tissue: In vitro and in vivo evaluations. J. Clin. Periodontol. 2011, 38, 721-731. [CrossRef] [PubMed]

263. Ma, Z.; Li, S.; Song, Y.; Tang, L.; Ma, D.; Liu, B.; Jin, Y. The biological effect of dentin noncollagenous proteins (DNCPs) on the human periodontal ligament stem cells (HPDLSCs) in vitro and in vivo. Tissue Eng. Part A 2008, 14, 2059-2068. [CrossRef] [PubMed]

264. Kim, S.H.; Kim, K.H.; Seo, B.M.; Koo, K.T.; Kim, T.I.; Seol, Y.J.; Ku, Y.; Rhyu, I.C.; Chung, C.P.; Lee, Y.M. Alveolar bone regeneration by transplantation of periodontal ligament stem cells and bone marrow stem cells in a canine peri-implant defect model: A pilot study. J. Periodontol. 2009, 80, 1815-1823. [CrossRef]

265. Liu, Y.; Zheng, Y.; Ding, G.; Fang, D.; Zhang, C.; Bartold, P.M.; Gronthos, S.; Shi, S.; Wang, S. Periodontal ligament stem cell-mediated treatment for periodontitis in miniature swine. Stem Cells 2008, 26, 1065-1073. [CrossRef] [PubMed]

266. Jin, Q.M.; Anusaksathien, O.; Webb, S.A.; Rutherford, R.B.; Giannobile, W.V. Gene therapy of bone morphogenetic protein for periodontal tissue engineering. J. Periodontol. 2003, 74, 202-213. [CrossRef]

267. Park, S.Y.; Kim, K.H.; Gwak, E.H.; Rhee, S.H.; Lee, J.C.; Shin, S.Y.; Koo, K.T.; Lee, Y.M.; Seol, Y.J. Ex vivo bone morphogenetic protein 2 gene delivery using periodontal ligament stem cells for enhanced re-osseointegration in the regenerative treatment of peri-implantitis. J. Biomed. Mater. Res. A 2015, 103, 38-47. [CrossRef]

268. Park, J.C.; Lee, S.M.; Kim, J.C.; Yun, J.H.; Cho, K.S.; Im, G.I.; Kim, B.S.; Kim, C.S. Effect of humoral factors from hPDLSCs on the biologic activity of hABCs. Oral Dis. 2012, 18, 537-547. [CrossRef]

269. Sculean, A.; Nikolidakis, D.; Nikou, G.; Ivanovic, A.; Chapple, I.L.; Stavropoulos, A. Biomaterials for promoting periodontal regeneration in human intrabony defects: A systematic review. Periodontology 2000 2015, 68, 182-216. [CrossRef]

270. Seciu, A.-M.; Craciunescu, O.; Stanciuc, A.-M.; Zarnescu, O. Tailored Biomaterials for Therapeutic Strategies Applied in Periodontal Tissue Engineering. Stem Cells Dev. 2019, 28, 963-973. [CrossRef]

271. Tsumanuma, Y.; Iwata, T.; Washio, K.; Yoshida, T.; Yamada, A.; Takagi, R.; Ohno, T.; Lin, K.; Yamato, M.; Ishikawa, I.; et al. Comparison of different tissue-derived stem cell sheets for periodontal regeneration in a canine 1-wall defect model. Biomaterials 2011, 32, 5819-5825. [CrossRef]

272. Yu, Y.; Mu, J.; Fan, Z.; Lei, G.; Yan, M.; Wang, S.; Tang, C.; Wang, Z.; Yu, J.; Zhang, G. Insulin-like growth factor 1 enhances the proliferation and osteogenic differentiation of human periodontal ligament stem cells via ERK and JNK MAPK pathways. Histochem. Cell Biol. 2012, 137, 513-525. [CrossRef]

273. McAllister, B.S. Stem cell-containing allograft matrix enhances periodontal regeneration: Case presentations. Int. J. Periodontics Restor. Dent. 2011, 31, 149-155.

274. Feng, F.; Akiyama, K.; Liu, Y.; Yamaza, T.; Wang, T.M.; Chen, J.H.; Wang, B.B.; Huang, G.T.; Wang, S.; Shi, S. Utility of PDL progenitors for in vivo tissue regeneration: A report of 3 cases. Oral Dis 2010, 16, 20-28. [CrossRef] [PubMed]

275. Chen, F.M.; Gao, L.N.; Tian, B.M.; Zhang, X.Y.; Zhang, Y.J.; Dong, G.Y.; Lu, H.; Chu, Q.; Xu, J.; Yu, Y.; et al. Treatment of periodontal intrabony defects using autologous periodontal ligament stem cells: A randomized clinical trial. Stem Cell Res. Ther. 2016, 7, 33. [CrossRef]

276. Lieberman, J.R.; Daluiski, A.; Einhorn, T.A. The role of growth factors in the repair of bone. Biology and clinical applications. J. Bone Jt. Surg Am. 2002, 84, 1032-1044. [CrossRef] 
277. Strauss, F.J.; Nasirzade, J.; Kargarpoor, Z.; Stahli, A.; Gruber, R. Effect of platelet-rich fibrin on cell proliferation, migration, differentiation, inflammation, and osteoclastogenesis: A systematic review of in vitro studies. Clin. Oral Investig. 2020, 24, 569-584. [CrossRef] [PubMed]

278. Dragonas, P.; Schiavo, J.H.; Avila-Ortiz, G.; Palaiologou, A.; Katsaros, T. Plasma rich in growth factors (PRGF) in intraoral bone grafting procedures: A systematic review. J. Cranio-Maxillo-Facial Surg. 2019, 47, 443-453. [CrossRef] [PubMed]

279. Qiao, J.; Duan, J.; Zhang, Y.; Chu, Y.; Sun, C. The effect of concentrated growth factors in the treatment of periodontal intrabony defects. Future Sci. Oa 2016, 2, FS136. [CrossRef] [PubMed]

280. Elgendy, E.A.; Abo Shady, T.E. Clinical and radiographic evaluation of nanocrystalline hydroxyapatite with or without platelet-rich fibrin membrane in the treatment of periodontal intrabony defects. J. Indian Soc. Periodontol. 2015, 19, 61-65. [CrossRef]

281. Agarwal, A.; Gupta, N.D.; Jain, A. Platelet rich fibrin combined with decalcified freeze-dried bone allograft for the treatment of human intrabony periodontal defects: A randomized split mouth clinical trail. Acta Odontol. Scand. 2016, 74, 36-43. [CrossRef]

282. Biswas, S.; Sambashivaiah, S.; Kulal, R.; Bilichodmath, S.; Kurtzman, G.M. Comparative Evaluation of Bioactive Glass (Putty) and Platelet Rich Fibrin in Treating Furcation Defects. J. Oral Implantol. 2016, 42, 411-415. [CrossRef] [PubMed]

283. Pradeep, A.R.; Nagpal, K.; Karvekar, S.; Patnaik, K.; Naik, S.B.; Guruprasad, C.N. Platelet-rich fibrin with 1\% metformin for the treatment of intrabony defects in chronic periodontitis: A randomized controlled clinical trial. J. Periodontol. 2015, 86, 729-737. [CrossRef] [PubMed]

284. Kornsuthisopon, C.; Pirarat, N.; Osathanon, T.; Kalpravidh, C. Autologous platelet-rich fibrin stimulates canine periodontal regeneration. Sci. Rep. 2020, 10, 1850. [CrossRef]

285. Fang, D.; Hu, S.; Liu, Y.; Quan, V.-H.; Seuntjens, J.; Tran, S.D. Identification of the active components in Bone Marrow Soup: A mitigator against irradiation-injury to salivary glands. Sci. Rep. 2015, 5, 16017. [CrossRef]

286. Kang, W.; Liang, Q.; Du, L.; Shang, L.; Wang, T.; Ge, S. Sequential application of bFGF and BMP-2 facilitates osteogenic differentiation of human periodontal ligament stem cells. J. Periodontal. Res. 2019, 54, 424-434. [CrossRef] [PubMed]

287. Li, F.; Yu, F.; Xu, X.; Li, C.; Huang, D.; Zhou, X.; Ye, L.; Zheng, L. Evaluation of Recombinant Human FGF-2 and PDGF-BB in Periodontal Regeneration: A Systematic Review and Meta-Analysis. Sci. Rep. 2017, 7, 65. [CrossRef] [PubMed]

288. Kelly, M.P.; Vaughn, O.L.; Anderson, P.A. Systematic Review and Meta-Analysis of Recombinant Human Bone Morphogenetic Protein-2 in Localized Alveolar Ridge and Maxillary Sinus Augmentation. J. Oral Maxillofac. Surg 2016, 74, 928-939. [CrossRef]

289. Gestrelius, S.; Lyngstadaas, S.P.; Hammarström, L. Emdogain-Periodontal regeneration based on biomimicry. Clin. Oral Investig. 2000, 4, 120-125. [CrossRef]

290. Tokiyasu, Y.; Takata, T.; Saygin, E.; Somerman, M. Enamel Factors Regulate Expression of Genes Associated With Cementoblasts. J. Periodontol. 2000, 71, 1829-1839. [CrossRef]

291. Wang, S.S.; Rausch-fan, X.; Andrukov, O.; Lin, Y.; Lin, L.S.; Shi, B. The effect of emdogain on proliferation and differentiation of co-cultured osteoblasts and endothelial cells. China J. Oral Maxillofac. Surg. 2019, 17, 32-39.

292. Talebi Ardakani, M.R.; Meimandi, M.; Shaker, R.; Golmohammadi, S. The Effect of Platelet-Rich Fibrin (PRF), Plasma Rich in Growth Factors (PRGF), and Enamel Matrix Proteins (Emdogain) on Migration of Human Gingival Fibroblasts. J. Dent. (Shiraz.) 2019, 20, 232-239.

293. Takeuchi, T.; Masuno, K.; Kato, H.; Taguchi, Y.; Umeda, M.; Okusa, N.; Tanaka, A.; Tominaga, K. A Human Amelogenin-Derived Oligopeptide Enhances Osteogenic Differentiation of Human Periodontal Ligament Stem Cells. J. Hard Tissue Biol. 2019, 28, 251-258. [CrossRef]

294. Esposito, M.; Grusovin, M.G.; Papanikolaou, N.; Coulthard, P.; Worthington, H.V. Enamel matrix derivative (Emdogain $(\mathrm{R}))$ for periodontal tissue regeneration in intrabony defects. Cochrane Database Syst. Rev. 2009, 2009, CD003875. [CrossRef] [PubMed]

295. Wiegand, A.; Attin, T. Efficacy of enamel matrix derivatives (Emdogain ${ }^{\circledR}$ ) in treatment of replanted teeth-A systematic review based on animal studies. Dent. Traumatol. 2008, 24, 498-502. [CrossRef]

296. Mohamed, R.N.; Basha, S.; Al-Thomali, Y.; Tawfik Enan, E. Enamel matrix derivative (Emdogain) in treatment of replanted teeth-A systematic review. Acta Odontol. Scand. 2019, 77, 168-172. [CrossRef] 
297. Lekovic, V.; Milinkovic, I.; Aleksic, Z.; Jankovic, S.; Stankovic, P.; Kenney, E.B.; Camargo, P.M. Platelet-rich fibrin and bovine porous bone mineral vs. platelet-rich fibrin in the treatment of intrabony periodontal defects. J. Periodontal. Res. 2012, 47, 409-417. [CrossRef]

298. Lindhe, J. Clinical periodontology and implant dentistry; Lang, N.P., Karring, T., Eds.; Blackwell Munksgaard: Copenhagen, Denmark, 2003; Volume 4, pp. 650-754.

299. Nyman, S. Bone regeneration using the principle of guided tissue regeneration. J. Clin. Periodontol. 1991, 18, 494-498. [CrossRef]

300. Bottino, M.C.; Thomas, V.; Schmidt, G.; Vohra, Y.K.; Chu, T.M.; Kowolik, M.J.; Janowski, G.M. Recent advances in the development of GTR/GBR membranes for periodontal regeneration-A materials perspective. Dent. Mater. 2012, 28, 703-721. [CrossRef]

301. Goker, F.; Larsson, L.; Del Fabbro, M.; Asa'ad, F. Gene Delivery Therapeutics in the Treatment of Periodontitis and Peri-Implantitis: A State of the Art Review. Int. J. Mol. Sci. 2019, 20, 20. [CrossRef]

302. Zhang, N.; Nichols, H.L.; Tylor, S.; Wen, X. Fabrication of nanocrystalline hydroxyapatite doped degradable composite hollow fiber for guided and biomimetic bone tissue engineering. Mater. Sci. Eng. C 2007, 27, 599-606. [CrossRef]

303. Jia, J.; Liu, G.; Guo, Z.-X.; Yu, J.; Duan, Y. Preparation and characterization of soluble eggshell membrane protein/PLGA electrospun nanofibers for guided tissue regeneration membrane. J. Nanomater. 2012, 2012, 282736. [CrossRef]

304. Gredes, T.; Kubasiewicz-Ross, P.; Gedrange, T.; Dominiak, M.; Kunert-Keil, C. Comparison of surface modified zirconia implants with commercially available zirconium and titanium implants: A histological study in pigs. Implant Dent. 2014, 23, 502-507. [CrossRef] [PubMed]

305. Le Gall, M.; Lauret, J.; Saadoun, A. Mastication forces and implant-bearing surface. Pract. Periodontics Aesthetic Dent. Ppad 1994, 6, 37.

306. Murphy, K.G.; Polack, M.A.; Arzadon, J.M.; Hickerson, R.D.; Scheyer, E.T. A Report of Three Cases from an Ongoing Prospective Clinical Study on a Novel Pink Biomimetic Implant System. Compend. Contin. Educ. Dent. 2016, 37, S1-S12. [PubMed]

307. Sicilia, A.; Cuesta, S.; Coma, G.; Arregui, I.; Guisasola, C.; Ruiz, E.; Maestro, A. Titanium allergy in dental implant patients: A clinical study on 1500 consecutive patients. Clin. Oral Implant. Res. 2008, 19, 823-835. [CrossRef]

308. Barwacz, C.A.; Brogden, K.A.; Stanford, C.M.; Dawson, D.V.; Recker, E.N.; Blanchette, D. Comparison of pro-inflammatory cytokines and bone metabolism mediators around titanium and zirconia dental implant abutments following a minimum of 6 months of clinical function. Clin. Oral Implant. Res. 2015, 26, e35-e41. [CrossRef]

309. Houshmand, A.; Donkiewicz, P.; Smeets, R.; Jung, O.; Barbeck, M. Incidental finding of a degrading zirconia dental implant 29 months after implantation: Histological and histomorphometrical analysis. J. Biomed. Mater. Res. Part B Appl. Biomater. 2018, 106, 2919-2923. [CrossRef]

310. Shiu, H.T.; Goss, B.; Lutton, C.; Crawford, R.; Xiao, Y. Formation of blood clot on biomaterial implants influences bone healing. Tissue Eng. Part B Rev. 2014, 20, 697-712. [CrossRef]

311. Ananth, H.; Kundapur, V.; Mohammed, H.S.; Anand, M.; Amarnath, G.S.; Mankar, S. A Review on Biomaterials in Dental Implantology. Int. J. Biomed. Sci. 2015, 11, 113-120.

312. Kundu, R.; Rathee, M. Effect of platelet-rich-plasma (PRP) and implant surface topography on implant stability and bone. J. Clin. Diagn. Res. JCDR 2014, 8, ZC26. [CrossRef]

313. Strauss, F.J.; Stähli, A.; Gruber, R. The use of platelet-rich fibrin to enhance the outcomes of implant therapy: A systematic review. Clin. Oral Implant. Res. 2018, 29, 6-19. [CrossRef] [PubMed]

314. Song, W.; Ge, S. Application of Antimicrobial Nanoparticles in Dentistry. Molecules 2019, 24, 15. [CrossRef] [PubMed]

315. Kasraei, S.; Sami, L.; Hendi, S.; Alikhani, M.Y.; Rezaei-Soufi, L.; Khamverdi, Z. Antibacterial properties of composite resins incorporating silver and zinc oxide nanoparticles on Streptococcus mutans and Lactobacillus. Restor. Dent. Endod. 2014, 39, 109-114. [CrossRef]

316. Garner, S.J.; Nobbs, A.H.; McNally, L.M.; Barbour, M.E. An antifungal coating for dental silicones composed of chlorhexidine nanoparticles. J. Dent. 2015, 43, 362-372. [CrossRef] [PubMed]

317. Lee, J.H.; Jo, J.K.; Kim, D.A.; Patel, K.D.; Kim, H.W.; Lee, H.H. Nano-graphene oxide incorporated into PMMA resin to prevent microbial adhesion. Dent. Mater. 2018, 34, e63-e72. [CrossRef] [PubMed] 
318. Allan, I.; Newman, H.; Wilson, M. Antibacterial activity of particulate bioglass against supra- and subgingival bacteria. Biomaterials 2001, 22, 1683-1687. [CrossRef]

319. Wang, L.; Li, C.; Weir, M.D.; Zhang, K.; Zhou, Y.; Xu, H.H.K.; Reynolds, M.A. Novel multifunctional dental bonding agent for Class-V restorations to inhibit periodontal biofilms. RSC Adv. 2017, 7, 29004-29014. [CrossRef]

320. Wang, L.; Melo, M.A.; Weir, M.D.; Xie, X.; Reynolds, M.A.; Xu, H.H. Novel bioactive nanocomposite for Class-V restorations to inhibit periodontitis-related pathogens. Dent. Mater. 2016, 32, e351-e361. [CrossRef]

321. Wang, L.; Xie, X.; Imazato, S.; Weir, M.D.; Reynolds, M.A.; Xu, H.H.K. A protein-repellent and antibacterial nanocomposite for Class-V restorations to inhibit periodontitis-related pathogens. Mater Sci. Eng. C Mater Biol. Appl. 2016, 67, 702-710. [CrossRef]

322. do Nascimento, C.; Paulo, D.F.; Pita, M.S.; Pedrazzi, V.; de Albuquerque Junior, R.F. Microbial diversity of the supra- and subgingival biofilm of healthy individuals after brushing with chlorhexidine- or silver-coated toothbrush bristles. Can. J. Microbiol. 2015, 61, 112-123. [CrossRef]

323. Mackevica, A.; Olsson, M.E.; Hansen, S.F. The release of silver nanoparticles from commercial toothbrushes. J. Hazard. Mater. 2017, 322 Pt A, 270-275. [CrossRef]

324. Fernandes, J.S.; Gentile, P.; Pires, R.A.; Reis, R.L.; Hatton, P.V. Multifunctional bioactive glass and glass-ceramic biomaterials with antibacterial properties for repair and regeneration of bone tissue. Acta Biomater. 2017, 59, 2-11. [CrossRef] [PubMed]

325. Chen, Q.; Xu, J.; Yu, L.; Fang, X.-Y.; Khor, K. Spark plasma sintering of sol-gel derived $45 S 5$ Bioglass (R)-ceramics: Mechanical properties and biocompatibility evaluation. Mater. Sci. Eng. C 2012, 32, 494-502. [CrossRef]

326. Daguano, J.K.; Strecker, K.; Ziemath, E.C.; Rogero, S.O.; Fernandes, M.H.; Santos, C. Effect of partial crystallization on the mechanical properties and cytotoxicity of bioactive glass from the $3 \mathrm{CaO} . \mathrm{P}(2) \mathrm{O}\left({ }_{5}\right)-\mathrm{SiO}(2)-\mathrm{MgO}$ system. J. Mech. Behav. Biomed. Mater. 2012, 14, 78-88. [CrossRef] [PubMed]

327. Fernandes, J.S.; Gentile, P.; Moorehead, R.; Crawford, A.; Miller, C.A.; Pires, R.A.; Hatton, P.V.; Reis, R.L. Design and Properties of Novel Substituted Borosilicate Bioactive Glasses and Their Glass-Ceramic Derivatives. Cryst. Growth Des. 2016, 16, 3731-3740. [CrossRef]

328. Freeman, C.O.; Brook, I.M.; Johnson, A.; Hatton, P.V.; Hill, R.G.; Stanton, K.T. Crystallization modifies osteoconductivity in an apatite-mullite glass-ceramic. J. Mater Sci. Mater. Med. 2003, 14, 985-990. [CrossRef] [PubMed]

329. Kanchanarat, N.; Miller, C.; Hatton, P.; James, P.; Reaney, I. Early Stages of Crystallization in Canasite-Based Glass Ceramics. J. Am. Ceram. Soc. 2005, 88, 3198-3204. [CrossRef]

330. Wallace, K.E.; Hill, R.G.; Pembroke, J.T.; Brown, C.J.; Hatton, P.V. Influence of sodium oxide content on bioactive glass properties. J. Mater Sci. Mater. Med. 1999, 10, 697-701. [CrossRef]

331. Hench, L.L. The story of Bioglass. J. Mater. Sci. Mater. Med. 2006, 17, 967-978. [CrossRef]

332. Hench, L.L. Bioceramics: From Concept to Clinic. J. Am. Ceram. Soc. 1991, 74, 1487-1510. [CrossRef]

333. Hench, L.L. Bioceramics. J. Am. Ceram. Soc. 1998, 81, 1705-1728. [CrossRef]

334. Rahaman, M.N. Bioactive ceramics and glasses for tissue engineering. In Tissue Engineering Using Ceramics and Polymers; Woodhead Publishing: Cambridge, UK, 2014; pp. 67-114.

335. Ahmed, A.A.; Ali, A.A.; Mahmoud, D.; El-Fiqi, A. Preparation and Characterization of Antibacterial $\mathrm{P}_{2} \mathrm{O}_{5}-\mathrm{CaO}-\mathrm{Na}_{2} \mathrm{O}-\mathrm{Ag}_{2} \mathrm{O}$ Glasses. J. Biomed. Mater. Res. Part A 2011, 98, 132-142. [CrossRef] [PubMed]

336. Bellantone, M.; Williams, H.D.; Hench, L.L. Broad-spectrum bactericidal activity of Ag(2)O-doped bioactive glass. Antimicrob. Agents Chemother. 2002, 46, 1940-1945. [CrossRef]

337. Goh, Y.F.; Alshemary, A.Z.; Akram, M.; Abdul Kadir, M.; Hussain, R. In vitro Characterization of Antibacterial Bioactive Glass Containing Ceria. Ceram. Int. 2013, 40, 729-737. [CrossRef]

338. Mulligan, A.M.; Wilson, M.; Knowles, J.C. The effect of increasing copper content in phosphate-based glasses on biofilms of Streptococcus sanguis. Biomaterials 2003, 24, 1797-1807. [CrossRef]

339. Domingues, E.P.; Ribeiro, R.F.; Horta, M.C.R.; Manzi, F.R.; Cosso, M.G.; Zenobio, E.G. Vertical augmentation of the posterior atrophic mandible by interpositional grafts in a split-mouth design: A human tomography evaluation pilot study. Clin. Oral Implant. Res. 2017, 28, e193-e200. [CrossRef]

340. Paladini, F.; Pollini, M.; Sannino, A.; Ambrosio, L. Metal-Based Antibacterial Substrates for Biomedical Applications. Biomacromolecules 2015, 16, 1873-1885. [CrossRef] 
341. Simchi, A.; Tamjid, E.; Pishbin, F.; Boccaccini, A.R. Recent progress in inorganic and composite coatings with bactericidal capability for orthopaedic applications. Nanomedicine 2011, 7, 22-39. [CrossRef]

342. Vassena, C.; Fenu, S.; Giuliani, F.; Fantetti, L.; Roncucci, G.; Simonutti, G.; Romanò, C.L.; De Francesco, R.; Drago, L. Photodynamic antibacterial and antibiofilm activity of RLP068/Cl against Staphylococcus aureus and Pseudomonas aeruginosa forming biofilms on prosthetic material. Int. J. Antimicrob. Agents 2014, 44, 47-55. [CrossRef]

343. Mishnaevsky, L.; Levashov, E.; Valiev, R.Z.; Segurado, J.; Sabirov, I.; Enikeev, N.; Prokoshkin, S.; Solov'yov, A.V.; Korotitskiy, A.; Gutmanas, E.; et al. Nanostructured titanium-based materials for medical implants: Modeling and development. Mater. Sci. Eng. R Rep. 2014, 81, 1-19. [CrossRef]

344. Geetha, M.; Singh, A.; Asokamani, R.; Gogia, A. Ti based biomaterials, the ultimate choice for orthopaedic implants A review. Prog. Mater. Sci. 2009, 54, 397-425. [CrossRef]

345. D'Almeida, M.; Attik, N.; Amalric, J.; Brunon, C.; Renaud, F.; Abouelleil, H.; Toury, B.; Grosgogeat, B. Chitosan coating as an antibacterial surface for biomedical applications. PLoS ONE 2017, 12, e0189537. [CrossRef] [PubMed]

346. Deepthi, S.; Venkatesan, J.; Kim, S.K.; Bumgardner, J.D.; Jayakumar, R. An overview of chitin or chitosan/nano ceramic composite scaffolds for bone tissue engineering. Int. J. Biol. Macromol. 2016, 93 Pt B, 1338-1353. [CrossRef]

347. Anitha, A.; Sowmya, S.; Kumar, P.T.S.; Deepthi, S.; Chennazhi, K.P.; Ehrlich, H.; Tsurkan, M.; Jayakumar, R. Chitin and chitosan in selected biomedical applications. Prog. Polym. Sci. 2014, 39, 1644-1667. [CrossRef]

348. Archana, D.; Singh, B.K.; Dutta, J.; Dutta, P.K. In vivo evaluation of chitosan-PVP-titanium dioxide nanocomposite as wound dressing material. Carbohydr. Polym. 2013, 95, 530-539. [CrossRef] [PubMed]

349. Khor, E.; Lim, L.Y. Implantable applications of chitin and chitosan. Biomaterials 2003, 24, 2339-2349. [CrossRef]

350. Ahsan, S.M.; Thomas, M.; Reddy, K.K.; Sooraparaju, S.G.; Asthana, A.; Bhatnagar, I. Chitosan as biomaterial in drug delivery and tissue engineering. Int. J. Biol. Macromol. 2018, 110, 97-109. [CrossRef]

351. Behera, S.S.; Das, U.; Kumar, A.; Bissoyi, A.; Singh, A.K. Chitosan/TiO(2) composite membrane improves proliferation and survival of L929 fibroblast cells: Application in wound dressing and skin regeneration. Int. J. Biol. Macromol. 2017, 98, 329-340. [CrossRef]

352. Singla, A.K.; Chawla, M. Chitosan: Some pharmaceutical and biological aspects-An update. J. Pharm. Pharm. 2001, 53, 1047-1067. [CrossRef]

353. Raafat, D.; Sahl, H.G. Chitosan and its antimicrobial potential-a critical literature survey. Microb. Biotechnol. 2009, 2, 186-201. [CrossRef]

354. Kumirska, J.; Weinhold, M.; Thöming, J.; Stepnowski, P. Biomedical Activity of Chitin/Chitosan Based Materials-Influence of Physicochemical Properties Apart from Molecular Weight and Degree of N-Acetylation. Polymers 2011, 3, 1875-1901. [CrossRef]

355. Wenling, C.; Duohui, J.; Jiamou, L.; Yandao, G.; Nanming, Z.; Xiufang, Z. Effects of the degree of deacetylation on the physicochemical properties and Schwann cell affinity of chitosan films. J. Biomater. Appl. 2005, 20, 157-177. [CrossRef] [PubMed]

356. Tchemtchoua, V.T.; Atanasova, G.; Aqil, A.; Filée, P.; Garbacki, N.; Vanhooteghem, O.; Deroanne, C.; Noël, A.; Jérome, C.; Nusgens, B.; et al. Development of a chitosan nanofibrillar scaffold for skin repair and regeneration. Biomacromolecules 2011, 12, 3194-3204. [CrossRef] [PubMed]

357. Campos, D.M.; Toury, B.; D'Almeida, M.; Attik, G.N.; Ferrand, A.; Renoud, P.; Grosgogeat, B. Acidic pH resistance of grafted chitosan on dental implant. Odontology 2015, 103, 210-217. [CrossRef]

(C) 2020 by the authors. Licensee MDPI, Basel, Switzerland. This article is an open access article distributed under the terms and conditions of the Creative Commons Attribution (CC BY) license (http://creativecommons.org/licenses/by/4.0/). 